\title{
Primed to act
}

Citation for published version (APA):

Omarova, F. (2016). Primed to act: the effect of fibrinogen ' $Y$ ' on thrombin functions. [Doctoral Thesis, Maastricht University]. Maastricht University. https://doi.org/10.26481/dis.20161124fo

Document status and date:

Published: 01/01/2016

DOI:

10.26481/dis.20161124fo

Document Version:

Publisher's PDF, also known as Version of record

\section{Please check the document version of this publication:}

- A submitted manuscript is the version of the article upon submission and before peer-review. There can be important differences between the submitted version and the official published version of record.

People interested in the research are advised to contact the author for the final version of the publication, or visit the DOI to the publisher's website.

- The final author version and the galley proof are versions of the publication after peer review.

- The final published version features the final layout of the paper including the volume, issue and page numbers.

Link to publication

\footnotetext{
General rights rights.

- You may freely distribute the URL identifying the publication in the public portal. please follow below link for the End User Agreement:

www.umlib.nl/taverne-license

Take down policy

If you believe that this document breaches copyright please contact us at:

repository@maastrichtuniversity.nl

providing details and we will investigate your claim
}

Copyright and moral rights for the publications made accessible in the public portal are retained by the authors and/or other copyright owners and it is a condition of accessing publications that users recognise and abide by the legal requirements associated with these

- Users may download and print one copy of any publication from the public portal for the purpose of private study or research.

- You may not further distribute the material or use it for any profit-making activity or commercial gain

If the publication is distributed under the terms of Article $25 \mathrm{fa}$ of the Dutch Copyright Act, indicated by the "Taverne" license above, 
Primed to act: the effect of fibrinogen $\gamma^{\prime}$ on thrombin functions 
(C) Farida Omarova, Maastricht 2016

ISBN: 978-94-6328-121-8

All rights reserved. No part of this book may be reproduced or transmitted in any form or by any means, without prior permission from the author, or when appropriate, by the publishers of the publications.

Cover: Blood clot dissolving, Science Photo Library

Layout: Tiny Wouters and Farida Omarova

Production: Wöhrmann B.V. - Zutphen 


\title{
Primed to act: the effect of fibrinogen $\gamma^{\prime}$ on thrombin functions
}

\author{
PROEFSCHRIFT \\ ter verkrijging van de graad van doctor aan de Universiteit Maastricht, \\ op gezag van de Rector Magnificus, Prof. Dr. Rianne M. Letschert, \\ volgens het besluit van het College van Decanen, \\ in het openbaar te verdedigen op \\ donderdag, 24 november 2016 om 16:00 uur \\ door
}

Farida Omarova 


\section{Promotores}

Prof. Dr. J. Rosing

Prof. Dr. R.M. Bertina

\section{Co-promotor}

Dr. E. Castoldi

\section{Beoordelingscommissie}

Prof. Dr. U. Schotten, voorzitter

Prof. Dr. F.C.S. Ramaekers

Prof. Dr. J.C.M. Meijers (Sanquin Research, Amsterdam)

Dr. M.P.M. de Maat (Erasmus Medisch Centrum, Rotterdam)

The work described in this thesis was supported by the Dutch Thrombosis Foundation (grant nr. 2011-2).

Financial support by the Dutch Heart Foundation for the publication of this thesis is gratefully acknowledged 
"There are only two mistakes one can make along the road to truth; not going all the way, and not starting."

Buddha

әкеме және анама to my parents 

Table of contents:

Chapter 1

Chapter 2 Inhibition of thrombin-mediated factor V activation contributes to the anticoagulant activity of fibrinogen $\gamma^{\prime}$

Chapter 3 Fibrinogen $\gamma^{\prime}$ increases the sensitivity to activated protein $\mathrm{C}$ in normal and factor $\mathrm{V}$ Leiden plasma

Chapter $4 \quad$ Effects of negatively charged phospholipids and the fibrinogen $\gamma^{\prime}$ C-terminal peptide on factor $\mathrm{XI}$ activation by thrombin

Chapter 5 Effects of the fibrinogen $\gamma^{\prime}$ C-terminal peptide on thrombin-mediated activation of factor XIII and TAFI

Valorization 



\title{
Chapter 1
}

\author{
General introduction
}




\section{Hemostasis}

The hemostatic system maintains blood in a liquid state in the circulation and stops bleeding after vascular injury. Following vessel damage, the hemostatic response is executed in three steps. Firstly, the blood vessel constricts, reducing the blood flow at the site of injury. Secondly, platelets from the circulation adhere to the exposed subendothelial collagen and become activated. Upon activation, platelets release factors that attract other platelets and activate them at the site of injury. This results in the formation of a platelet plug that serves as a physical barrier to stop the bleeding. This process is called primary hemostasis. Activated platelets also release coagulation factors and expose negatively charged phospholipids that serve as a surface for coagulation reactions. The coagulation cascade (also known as secondary hemostasis) produces a stiff fibrin clot which stabilizes the platelet plug and traps other blood cells augmenting the clot. The clot is eventually dissolved in the process of fibrinolysis.

\section{Thrombosis and bleeding}

The components of the hemostatic system need to be carefully regulated to maintain the hemostatic balance and prevent blood loss as well as excessive blood clotting. Genetic or acquired factors can perturb this delicate balance, leading to pathological processes such as thrombosis or bleeding.

The formation of a blood clot inside a blood vessel that hinders the free flow of blood through the circulatory system is called thrombosis. The blood flow can detach the clot and pass it further in the blood vessels. Because of the differences in vessel size, the clot can occlude a smaller downstream vessel (thromboembolism) and cause ischemia in the region which is supplied with blood by that vessel. According to the affected vessel, arterial and venous thromboses are distinguished. Arterial thrombosis includes coronary artery disease, myocardial infarction, stroke and peripheral arterial disease. Venous thrombosis takes the form of deep vein thrombosis (DVT), usually affecting the deep veins of the leg, or pulmonary embolism (PE), which is the result of a clot fragment (embolus) that travelled through veins to the heart and from the heart through the pulmonary arteries to the lungs where it blocks the blood flow.

Bleeding occurs when the formation of the primary platelet plug or of the fibrin clot is defective. Besides traumatic injury-related bleeding, several genetic defects (von 
Willebrand disease, platelet disorders, and deficiencies of coagulation factors) can aggravate the blood loss.

\section{Blood coagulation}

Blood coagulation is a process involving several plasma proteins called coagulation factors, the final result being the formation of fibrin. Most coagulation factors are serine proteases or non-enzymatic cofactors synthesized by the liver and secreted into the circulation in inactive form. When coagulation is initiated, these inactive precursors are activated in a cascade manner, i.e. each active enzyme activates the following factor in the chain, often with the help of a non-enzymatic cofactor [1]. These reactions take place on the surface of cell membranes that provide a suitable binding site for the coagulation proteins and promote their interaction. Most coagulation factors (coagulation factor II, VII, IX and X) as well as some coagulation inhibitors (protein S, protein C) are vitamin K-dependent proteins. Vitamin $\mathrm{K}$ is required for the post-translational modification of glutamate residues to $\gamma$ carboxyglutamate (Gla) residues, which bind calcium ions with high affinity and thereby mediate binding of coagulation proteins to negatively charged phospholipid surfaces. This is why the coagulation process requires $\mathrm{Ca}^{2+}$.

\section{Coagulation cascade}

Blood coagulation starts when a blood vessel is damaged and tissue factor (TF) located in the subendothelial layer is exposed to the blood [2,3]. Traditionally, coagulation has been viewed as a process developing along two interconnected pathways, extrinsic and intrinsic. A schematic representation of the coagulation cascade is shown in Figure 1.1. The extrinsic pathway, also called tissue factor pathway, starts with a damage of the vessel wall and exposure of tissue factor (TF) located in the subendothelial layer [3]. TF binds activated coagulation factor VII (FVIla) that circulates in traces in plasma, forming a membrane-bound TF-FVIla complex that activates coagulation factor $X(F X)$. In the presence of phospholipids and $\mathrm{Ca}^{2+}$, activated factor $X(F X a)$ assembles with its cofactor activated factor $V(F V a)$ to form the prothrombinase complex, which converts prothrombin to thrombin, the most important enzyme/player of the coagulation cascade [4]. 


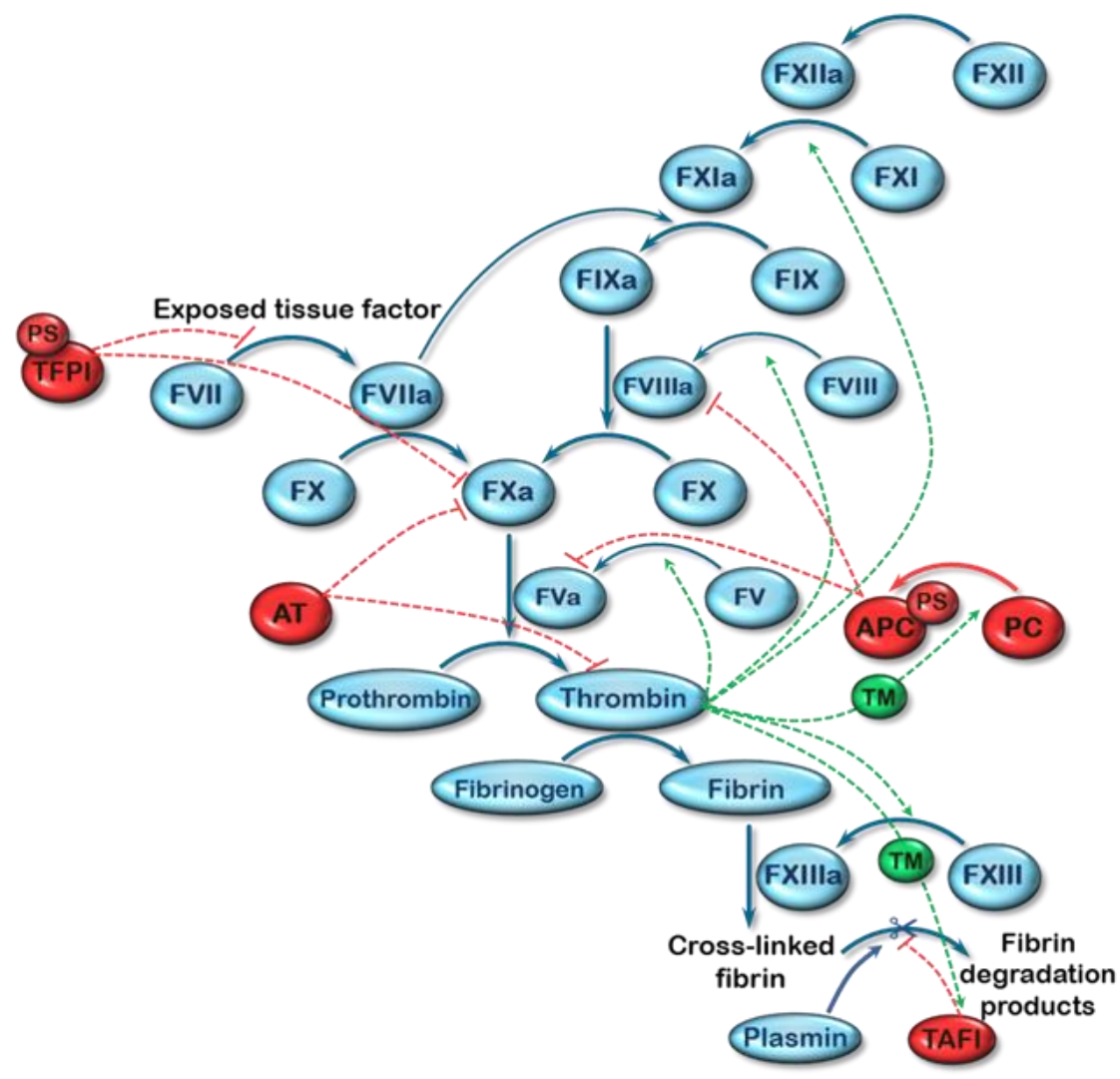

Figure 1.1 Schematic representation of blood coagulation and fibrinolysis. Coagulation factors are shown in blue. The proteins in red are the natural inhibitors of coagulation (TFPI, AT, protein C and protein S) and fibrinolysis (TAFI). Green arrows indicate positive feedback reactions of thrombin (with TM as a cofactor of some reactions).

The intrinsic pathway of coagulation starts with kallikrein- and high molecular weight kininogen-mediated activation of coagulation factor XII (FXII) on a negatively charged surface or collagen [5]. FXIla then activates factor XI (FXI), which in turn activates factor IX (FIX). FIXa requires a cofactor, factor VIIIa (FVIIIa), to activate FX that enters the prothrombinase complex. Thus, both pathways converge on the formation of the prothrombinase complex that generates thrombin, which converts fibrinogen into fibrin. 
In the modern view of coagulation the two classical pathways are linked via the positive feedback loops of thrombin and are parts of a single process that occurs in phases mostly on cell surfaces. In the initiation phase, only small amounts of thrombin are formed via TF pathway [6]. Additionally, the TF-FVIla complex can activate FIX, a component of the intrinsic pathway [7]. In the amplification phase, the first traces of thrombin further activate a number of coagulation factors located upstream in the cascade (FV, FVIII and FXI) that dramatically accelerate FX and prothrombin activation, thereby enhancing thrombin formation (Figure 1.1). In the last phase of coagulation, thrombin converts fibrinogen to fibrin (described below) and activates factor XIII (FXIII), which covalently cross-links the fibrin fibers to form a strong fibrin network.

\section{Regulation of coagulation}

The coagulation process is tightly regulated by several mechanisms acting at different levels of the cascade (Figure 1.1) to prevent excessive blood clotting or pathological hemostasis without vascular damage.

The initiation of coagulation by the TF/FVIla complex is inhibited by tissue factor pathway inhibitor (TFPI). TFPI is a multivalent kunitz-type protease inhibitor which first binds and inhibits the TF-FVIla complex via its Kunitz-1 domain and FXa via its Kunitz-2 domain [8]. TFPI has a cofactor, protein S, which binds to the Kunitz-3 domain and enhances the inhibitory activity of $\operatorname{TFPI}[9,10]$.

Another crucial anticoagulant system is the protein C pathway, which is initiated by thrombin itself. Thrombin, in complex with its receptor thrombomodulin (TM), activates protein $C$ on the surface on endothelial cells. Activated protein C (APC) proteolytically inactivates the non-enzymatic cofactors FVa and FVIIla. These reactions are stimulated by the APC-cofactors protein S and FV [11].

Antithrombin, which is a serine-protease inhibitor, is an important direct physiological inhibitor of thrombin and FXa [12]. The activity of antithrombin is largely increased by heparin. 


\section{Thrombin}

\section{Thrombin structure}

Thrombin is a central enzyme in the blood coagulation system due to its multiple functions in both the procoagulant and anticoagulant pathways. It is a serine protease whose zymogen (prothrombin) is encoded by the F2 gene located on chromosome 11 [13]. Prothrombin is a single-chain protein that consists of a Gla domain, 2 kringle domains and a catalytic domain. Prothrombin is activated by cleavage at R271 and R320, which yields two chains ( $A$ and B chains) covalently linked by a disulfide bond [14]. During its conversion from prothrombin, thrombin exposes not only its active site, but also two positively charged anion binding exosites which help thrombin to recognize its many substrates, cofactors and inhibitors [15-17]. The involvement of thrombin exosites in the interactions with its substrates is illustrated in Table 1.1. Thrombin cleaves its substrates after Arg residues and the structure of its active site allows interactions with hydrophobic residues on the $\mathrm{N}$-terminal side of the cleavage site [18].

\begin{tabular}{|c|c|c|c|}
\hline \multirow{2}{*}{ Platelets receptors } & Thrombin substrate & Exosite I & Exosite II \\
\hline Coagulation & PAR-1, PAR-4 & Yes & No \\
\hline & Fibrinogen A $\alpha$ chain & Yes & No \\
\hline & Fibrinogen B $\beta$ chain & Yes & No \\
\hline Fibrinogen $\gamma^{\prime}$ chain & No & Yes \\
\hline Fibrin cross-linking & FV & Yes & Yes \\
\hline Fibrinolysis & FVIII & Yes & Yes \\
\hline APC system & FXI & Yes & No \\
\hline Inhibitors & FXIII & Via fibrin & No \\
\hline & Protein C & Via TM & Via TM* \\
\hline & Antithrombin & No & Via TM* \\
\hline & $\alpha 2 M$ & Not known & Not known \\
\hline & HCII & Yes & Via heparin \\
\hline
\end{tabular}

Table 1.1 Involvement of thrombin exosites I and II in the interactions of thrombin with its many substrates and inhibitors. *Denotes binding interaction of chondroitin sulphate moiety. Modified from Lane et al. [16]. 
Another crucial feature of thrombin is the $\mathrm{Na}^{+}$-binding site, which is also formed during prothrombin activation [19]. Binding of $\mathrm{Na}^{+}$modulates the catalytic activity of thrombin towards its substrates [20]. Thrombin with mutated $\mathrm{Na}^{+}$-binding residues was originally shown to be more active towards the anticoagulant substrates $[21,22]$. Nevertheless, more recent data suggest that when the $\mathrm{Na}^{+}$-binding site is not occupied thrombin is present in various zymogen-like conformations and that $\mathrm{Na}^{+}$binding stabilizes the active conformation/state, increasing the activity of thrombin not only towards its procoagulant substrates, but also its anticoagulant substrate (protein C) [23]. However, the physiological role of $\mathrm{Na}^{+}$-binding to thrombin is unclear, since at the physiological $\mathrm{Na}^{+}$concentration $(140 \mathrm{mM})$ around $80 \%$ of the thrombin molecules have their $\mathrm{Na}^{+}$- binding site occupied with $\mathrm{Na}^{+}$[24].

\section{Thrombin substrates}

Thrombin is an extremely versatile enzyme with numerous functions in the haemostatic system. First of all, thrombin contributes to platelet activation by cleaving the protease-activated receptors (PARs). In addition, thrombin cleaves and activates several coagulation factors that contribute to thrombin generation (FV, FVIII, FXI), clot formation (fibrinogen) and clot stabilization (FXIII). After binding to thrombomodulin (TM) located on the endothelial cell membrane, thrombin loses affinity for these procoagulant substrates and activates protein C (an anticoagulant protein) and thrombin activatable fibrinolysis inhibitor (TAFI), a carboxypeptidase with anti-fibrinolytic activity (Figure 1.1).

\section{Platelets}

Thrombin is one of the numerous platelet activators. It activates platelets by binding and cleaving PAR1 and PAR4 on the platelet surface [25]. Cleavage of PAR1 is enhanced by binding of thrombin to the platelet receptor GPIb $\alpha$ with its exosite II [26]. This, in turn, activates an intracellular signaling pathway that leads to increase in intracellular $\mathrm{Ca}^{2+}$ concentration and supports the shape change of platelets [27]. 


\section{Fibrinogen}

Thrombin converts fibrinogen to fibrin [28] by cleaving fibrinopeptides $A$ and $B$ from the $A \alpha$ and $B \beta$ chains, respectively. This results in the production of protofibrils, which subsequently undergo lateral binding and cross-linking to create the stable fibrin clot that seals the vascular injury and stops the loss of blood. Thrombin exosite I is involved in the binding to fibrinogen, while exosite II binds only to the alternatively spliced $\gamma^{\prime}$ chain of fibrinogen (see below).

\section{FV}

Thrombin activates FV by limited proteolysis at R709, R1018 and R1545. The active site and both exosites of thrombin are involved in the process, exosite II is specifically needed for cleavage at R1545 [29]. FVa is a cofactor of FXa within the prothrombinase complex that converts prothrombin to thrombin.

\section{FVIII}

FVIII is structurally homologous to FV and is activated by thrombin upon cleavage at R372, R740, R1649 and R1689. Both exosites of thrombin are involved in FVIII activation [30]. Following activation, FVIII takes part in the intrinsic pathway as a cofactor for FIXa in the activation of FX.

FXI

$\mathrm{FXI}$ is a component of the contact system and is activated by thrombin via cleavage of the peptide bond between R369 and 1370. The activation of FXI by thrombin is stimulated by negatively charged surfaces, to which thrombin can bind via exosite II [31].

FXIII

FXIII is a tetramer composed of two A (catalytic) and two B (carrier) subunits. Thrombin cleaves off an activation peptide from both A subunits of FXIII, followed by full activation via $\mathrm{Ca}^{2+}$-mediated dissociation of the $\mathrm{B}$ subunits, with fibrinogen as a cofactor. FXIIla is a plasma transglutaminase that cross-links the fibrin fibers [32]. 
Protein C

Protein $C$ is the zymogen form of APC, which is cleaved by the thrombin/TM complex at R12 on the surface of endothelial cells [11]. Both thrombin exosites are involved in this reaction by binding to TM. APC is an important anticoagulant enzyme that proteolytically inactivates FVa and FVIIIa.

TAFI

TAFI is activated by thrombin through cleavage at R92, which splits off an N-terminal activation peptide. The rate of the activation is increased 1250 -fold when thrombin is in complex with TM [33], which binds to both exosites of thrombin. TAFla binds to plasminogen and cleaves C-terminal lysines on (fibrin)ogen, thereby preventing fibrinolysis [34].

\section{Thrombin inhibitors}

Since thrombin is such a potent and versatile enzyme, its activity needs to be tightly regulated. The main thrombin inhibitors are antithrombin, $\alpha_{2}$-macroglobulin (both very abundant, in the $\mu \mathrm{M}$-range) and heparin cofactor II.

Serpins (serine-protease inhibitors), such as antithrombin and heparin cofactor II, act as suicide substrates that trap thrombin in the acyl-enzyme intermediate and eventually cause it to unfold [35]. Their inhibitory activity is greatly enhanced by heparin, which bridges the serpin to thrombin exosite II. While antithrombin inhibits several coagulation enzymes (including FIXa, FXa and FXIa), heparin cofactor II is more specific for thrombin [12].

$\alpha_{2}$-macroglobulin is a general inhibitor of proteases that has a completely different mechanism of action. Thrombin cleaves $\alpha_{2}$-macroglobulin and forms a complex with it that protects the active site of thrombin from binding to its physiological substrates $[36,37]$.

\section{Fibrinogen}

Fibrinogen, the precursor of fibrin, is a complex glycoprotein of $340 \mathrm{kDa}$ present in plasma and in platelets. The fibrinogen molecule consists of a double set of three polypeptide chains: $A \alpha, B \beta$ and $\gamma$ [28] encoded by separate genes (FGA, FGB and FGG) 
located on the long arm of chromosome 4 [38]. Every fibrinogen molecule has a central $E$ domain and two lateral $D$ domains, each connected with the $E$ domain by a coiled coil region (Figure 1.2). Fibrinogen is synthesized in the liver and circulates in plasma at a physiological concentration of 2-4 g/L ( $\sim \mu \mathrm{M}$, one of the most abundant plasma proteins). As it is an acute phase protein, the concentration of fibrinogen increases with inflammation.

D region

E region

D region

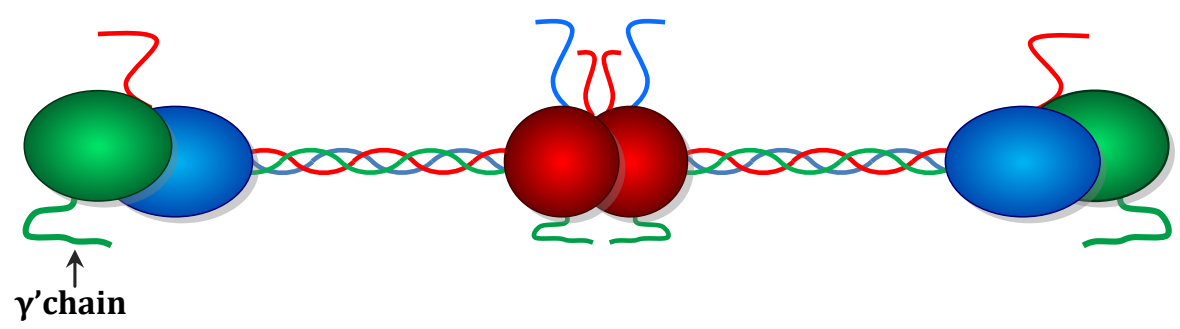

Figure 1.2 Schematic representation of a fibrinogen molecule. The fibrinogen molecule is composed of two outer $D$ regions and a central $E$ region. Each molecule comprises a double set of disulfide-linked polypeptide chains: A $\alpha$ (red), B $\beta$ (blue) and $\gamma$ (green). A less abundant isoform of the $\gamma$ chain, the $\gamma^{\prime}$ chain, has a unique 20 amino acid extension at its $\mathrm{C}$-terminus that is located in the $\mathrm{D}$ region.

Fibrinogen is best known for its function as the precursor of fibrin, but it also expresses a poorly understood anticoagulant activity as a thrombin inhibitor (antithrombin I, see below), which is the main subject of this thesis. In addition, fibrinogen plays a role in primary haemostasis by forming bridges between platelets during platelet aggregation via integrin-mediated interactions. Finally, it is a structural component of the extracellular matrix.

\section{Fibrin formation, cross-linking and degradation}

Fibrinogen is converted to fibrin by thrombin-mediated cleavage of fibrinopeptides $A$ and $B$, which is followed by spontaneous polymerization of fibrin fibers. Thrombin first cleaves off fibrinopeptide $A$ from the $\mathrm{N}$-terminal end of each $\mathrm{A} \alpha$ chain, causing fibrin 
monomers to spontaneously arrange in protofibrils held together by interactions between the $D$ domains of each fibrin molecule and the $E$ domains of other fibrin molecules. This process is followed by slow cleavage of fibrinopeptide $B$ from the $B \beta$ chains [39], which leads to the lateral aggregation of hundreds to thousands of protofibrils and the formation of insoluble fibrin fibers [40].

The fibrin structure is stabilized by covalent $\gamma$-glutamyl- $\varepsilon$-lysyl bonds between $\gamma$ chains of the same protofibril, between $\alpha$ chains of different protofibrils and also between $\alpha$ and $Y$ chains [41]. These cross-linking reactions are catalyzed by FXIIla, a transglutaminase that circulates in plasma as an inactive precursor and is activated by thrombin in the presence of polymerizing fibrin.

Fibrin is eventually degraded by plasmin (a serine protease) in the process of fibrinolysis [42]. Plasmin is generated from circulating plasminogen by tissue-type plasminogen activator (tPA) or by urokinase (UPA). This reaction is greatly enhanced when both plasminogen and TPA are bound to fibrin via their lysine-binding sites. Plasmin-mediated cleavage of fibrin yields soluble fibrin degradation products (including D-dimer) and also exposes C-terminal lysine residues that recruit more tPA and plasminogen to the fibrin surface. Fibrinolysis is regulated by several inhibitors. The most important are plasminogen activator inhibitor 1 (PAI-1), $\alpha_{2}$-antiplasmin (A2AP, a direct plasmin inhibitor) and $\mathrm{TAFI}$, a pro-carboxypeptidase that can be activated by thrombin bound to TM. The thrombin/TM complex converts TAFI into TAFla, which inhibits fibrinolysis by removing the C-terminal lysine residues that serve as anchor points for tPA and plasminogen on fibrin.

\section{Anticoagulant function of fibrin(ogen)}

Apart from its essential role in blood clotting, fibrin(ogen) also fulfills an important anticoagulant function by 'adsorbing' and sequestering thrombin [43]. The physiological relevance of this antithrombotic mechanism, known as 'antithrombin I' activity, is underlined by the paradoxical observation that congenital deficiency of fibrinogen can lead to thrombotic events as well as bleeding [44, 45]. In fact, not only hyperfibrinogenemia, but also hypofibrinogenemia and some dysfibrinogenemias with impaired thrombin-binding capacity of fibrin(ogen), have been shown to increase the risk for venous [46-48] and arterial thrombosis [49, 50].

The interaction between thrombin and fibrin(ogen) is very complex and involves lowaffinity binding sites for thrombin exosite $\mathrm{I}$ and a high-affinity binding site for 
thrombin exosite II. While the former are present in the E domain of all fibrinogen molecules, the latter is present only on fibrinogen molecules that contain the alternatively spliced $\gamma^{\prime}$ chain (see below). How binding to fibrin(ogen) influences thrombin activity towards its many substrates and its susceptibility to its natural inhibitors is not yet well understood and is the main objective of this thesis.

\section{Fibrinogen $\gamma^{\prime}$}

\section{Genetics and structure}

The FGG gene encodes two alternatively spliced isoforms of the fibrinogen $\gamma$ chain, the more abundant $\gamma A$ and the less abundant $\gamma^{\prime}$. FGG comprises 10 exons and 9 introns with two potential polyadenylation sites, one in intron 9 and one downstream of exon 10 (Figure 1.3). Splicing of intron 9 and use of the polyadenylation site downstream of exon 10 yields the mRNA encoding the $\gamma A$ chain. Vice versa, use of the alternative polyadenylation signal in intron 9 causes part of intron 9 to be retained in the mature mRNA and produces the mRNA encoding the $\gamma^{\prime}$ chain (Figure 1.3). These two variants of the fibrinogen $\gamma$ chain differ in their C-terminal ends. The $\gamma A$ chain is 411 amino acids long and its C-terminal sequence (AGDV, YA 408-411), encoded by exon 10, contains a platelet binding site. In contrast, the less abundant $\gamma^{\prime}$ chain has a unique 20 amino acid sequence originating from the unspliced part of intron 9 (VPREHPAETEYDSLYPEDDL, $\gamma^{\prime}$ 408-427) and replacing the last 4 amino acids of the $\gamma A$ chain [51]. The $\gamma^{\prime}$ tail contains 7 acidic residues and two sulfated tyrosines which make it highly anionic and determine the special properties of the $\gamma^{\prime}$ chain, including highaffinity binding to thrombin exosite II (see below). Since each fibrinogen molecule contains two $\gamma$ chains, random pairing of the two $\gamma$ chain isoforms leads to the formation of three types of fibrinogen molecules: $\mathrm{VA} / \mathrm{\gamma A}(80-90 \%$ of plasma fibrinogen), $\gamma A / \gamma^{\prime}(10-15 \%)$ and $\gamma^{\prime} / \gamma^{\prime}(<1 \%)$ [52]. The term fibrinogen $\gamma^{\prime}$ is often used to indicate all fibrinogen molecules that contain at least one $\gamma^{\prime}$ chain. A truncated form of the $\gamma^{\prime}$ chain that lacks the last 4 C-terminal residues (EDDL) accounts for 3$34 \%$ of all $\gamma^{\prime}$ chain in plasma [53]. This form does not contain the binding site for thrombin exosite II. 


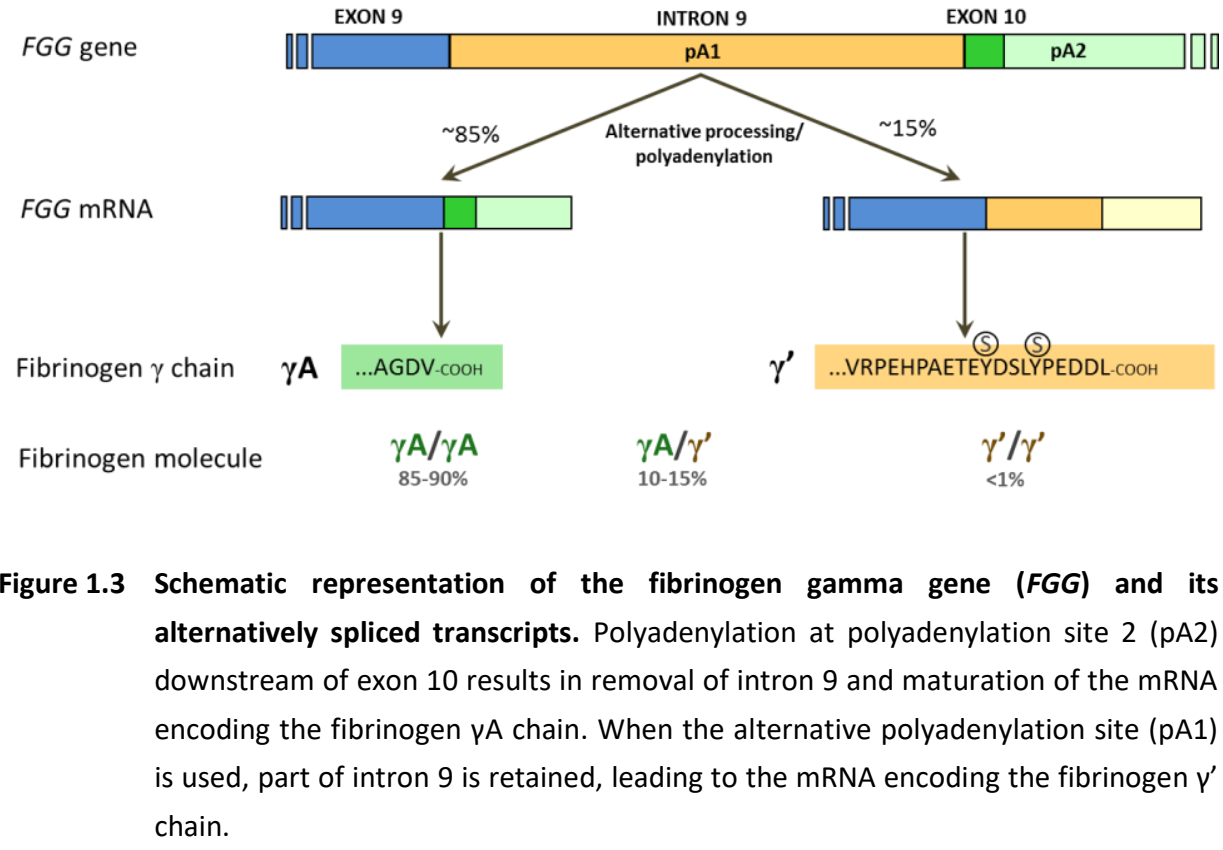

\section{Interaction with thrombin}

The C-terminal end of the fibrinogen $\gamma^{\prime}$ chain (residues A414-L427) contains a highaffinity binding site for thrombin exosite II $\left(K_{d} \sim 0.01 \mu \mathrm{M}\right) \quad[54,55]$, the negative charges and sulfation of $\mathrm{Y} 418$ and $\mathrm{Y} 422$ being crucial for this interaction [56]. Interaction of the fibrinogen $\gamma^{\prime}$ chain with thrombin exosite II has been reported to inhibit thrombin-mediated FVIII activation [57] and platelet aggregation through the PAR-1 receptor $[58,59]$. These properties may explain (part of) the antithrombin I activity of fibrin(ogen) [60].

\section{Other properties}

Besides binding to thrombin exosite $I$, the $\gamma^{\prime}$ chain also has other thrombinindependent properties different from the $\gamma A$ chain. Namely, the $\gamma^{\prime}$ chain of fibrinogen binds the $B$ subunits of FXIII with a higher affinity than the $\gamma A$ chain $[61,62]$. This suggests that fibrinogen $\gamma \mathrm{A} / \mathrm{\gamma}^{\prime}$ functions as a carrier of FXIII in plasma, bringing it to the site of a forming fibrin clot, so that FXIIla can cross-link the fibrin fibers and thereby make the fibrin clot more resistant to fibrinolysis [63]. 
Furthermore, fibrinogen containing the $\gamma^{\prime}$ chain affects the fibrin clot structure. As the polymerization and protofibril formation rate is lower for $\gamma \mathrm{A} / \gamma^{\prime}$ fibrinogen, it also changes the ultrastructure of the fibers [64]. Fibrin fibers made of fibrinogen $\gamma A / \gamma^{\prime}$ are thinner and create a more branched, non-uniformly arranged network with smaller pores than those formed from $\gamma \mathrm{A} / \mathrm{\gamma A}$ fibrinogen $[64,65]$. Moreover, clots formed from $\gamma A / \gamma^{\prime}$ fibrinogen are more resistant to fibrinolysis $[66,67]$.

\section{Clinical associations}

Common single nucleotide polymorphisms (SNPs) in the FGG gene are associated with the levels of fibrinogen $\gamma^{\prime}$ in plasma but not with total fibrinogen levels. The common FGG H2 haplotype (minor allele frequency 0.270 ) predicts low levels of the $\gamma^{\prime}$ chain variant, because one of its tagging SNPs (10034C>T, rs2066865) enhances the polyadenylation downstream of exon 10 and thereby shifts the production towards the $\gamma A$ form [68]. In contrast, the FGG H3 haplotype (minor allele frequency 0.307) is associated with relatively high levels of the fibrinogen $\gamma^{\prime}$ chain. Interestingly, a number of studies have shown that the FGG H2 haplotype is associated with increased risk of deep venous thrombosis [68-71], suggesting that the fibrinogen $\gamma^{\prime}$ chain influences the hemostatic balance.

The relationship between fibrinogen $\gamma^{\prime}$ levels and arterial thrombosis is still a matter of debate. Epidemiological studies have shown an increased $\gamma^{\prime} /$ total fibrinogen ratio in patients with peripheral artery disease, ischemic stroke and myocardial infarction [72], as well as an association of elevated fibrinogen $\gamma^{\prime}$ levels with coronary artery disease [73]. However, all these studies were retrospective, and a more recent prospective study [74] has revealed that this association is not causal, but simply reflects the effect of inflammation on fibrinogen $\gamma^{\prime}$ expression [75]. Interestingly, an animal study showed that the injection of human $\mathrm{\gamma A} / \mathrm{\gamma A}$ fibrinogen in mice shortened the time to carotid artery occlusion, whereas the infusion of human fibrinogen $\gamma^{\prime}$ did not [76]. Besides that, fibrinogen $\gamma^{\prime}$ decreased the level of thrombin-antithrombin complexes in plasma, suggesting an antithrombotic effect of fibrinogen $\gamma^{\prime}$ also in vivo [76]. This study showed that, in contrast to fibrinogen $\gamma A /{ }^{\prime} A$, fibrinogen $\gamma^{\prime}$ does not promote arterial thrombosis in vivo. 


\section{Thrombin generation test}

The thrombin generation test is a global assay that measures the potential of a plasma sample to generate thrombin after initiation of coagulation with TF or another trigger in vitro. Since thrombin generation is usually measured in citrated platelet-poor plasma, synthetic phospholipid vesicles (a combination of phosphatidylserine, phosphatidylcholine and phosphatidylethanolamine) are added as a procoagulant surface in the presence of $\mathrm{CaCl}_{2}$. In the Calibrated Automated Thrombogram (CAT) test, the formation and degradation of thrombin in plasma is followed using a lowaffinity fluorogenic substrate (Z-Gly-Gly-Arg-AMC) added directly to plasma [77]. In order to convert the fluorescence signal into thrombin concentration, each measurement is calibrated against the fluorescence generated by a fixed amount of thrombin activity in the same sample plasma [78]. The fluorescence signal is converted into a thrombin generation curve by dedicated software.

The thrombin generation curve shows the generation and decay of thrombin in plasma (Figure 1.4). It starts with a lag time that represents the initiation phase of coagulation. The lag time corresponds with the plasma clotting time, during which only a minimal amount of thrombin is formed. This is followed by the rapid formation of a large amount of thrombin (propagation phase), which is reflected in the peak of the thrombin generation curve. Finally, under the influence of thrombin inhibitors, mainly antithrombin, thrombin activity goes back to zero in the descending part of the curve (termination phase). The thrombin generation curve can be described in terms of several quantitative parameters, such as the lag time, peak height and endogenous thrombin potential (ETP), which corresponds to the area under the curve and represents the total enzymatic work of the thrombin generated during the entire time-course. In hypercoagulable conditions, the lag time is shortened, while the peak height and ETP are increased. Conversely, a prolonged lag time and reduced peak height and ETP indicate a hypocoagulable state [79]. 


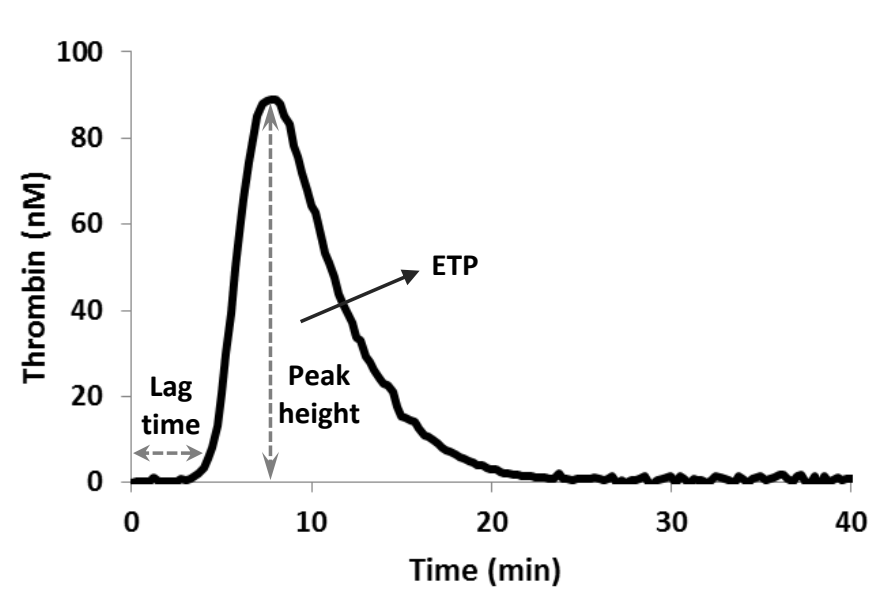

Figure 1.4 Thrombin generation curve. The main parameters that describe the thrombin generation curve are indicated.

The thrombin generation assay can be performed under various experimental conditions. In particular, it is possible to use different triggers and trigger concentrations, add TM or APC to challenge the protein C pathway, or include antibodies to selectively knock out a particular protein. This flexibility is a very useful feature of the test, as the "assay determinants", i.e. the coagulation factors and inhibitors that influence the assay outcome, vary according to the experimental conditions. For example, at low tissue factor concentration both the extrinsic and the intrinsic pathway contribute to thrombin generation, whereas at high tissue factor thrombin is generated almost exclusively via the extrinsic pathway.

When chromogenic substrates were used to measure thrombin generation, fibrinogen and platelets had to be removed from the plasma, as the turbidity increased when plasma clotted and interfered with the chromogenic signal. The advantage of the CAT method is that thrombin generation can be measured in the presence of fibrinogen, as the fluorescence signal used for the thrombin generation assay is not affected by clot formation [80]. This allows the determination of fibrinogen effect on thrombin generation which is essential for the studies presented in this thesis. 


\section{Outline of this thesis}

The existence of the anticoagulant properties of fibrinogen has been known for a long time [43]. However, the underlying mechanism is still not well understood. Recently, it has become clear that much of the antithrombin I activity of fibrinogen is attributable to the fibrinogen $\gamma^{\prime}$ chain, which was reported to inhibit thrombin-mediated platelet aggregation [58, 59] and FVIII activation [57]. In this thesis we have studied the effects of fibrinogen $\gamma^{\prime}$ on the activity of thrombin towards its other substrates, namely FV, FXI, FXIII, protein C and TAFI. To this end, we have used a synthetic peptide mimicking the $\mathrm{C}$-terminal sequence of the fibrinogen $\gamma^{\prime}$ chain.

In Chapter $\mathbf{2}$ we show that total fibrinogen and especially fibrinogen $\gamma^{\prime}$ have an overall anticoagulant action on thrombin generation in plasma. Moreover, we report on the effect of the fibrinogen $\gamma^{\prime}$ C-terminal peptide on FV activation by thrombin.

In a population of 188 heterozygous carriers of the FV Leiden mutation we observed that the common fibrinogen haplotype $F G G \mathrm{H} 2$, which is associated with relatively low levels of fibrinogen $\gamma^{\prime}$, increases the resistance of plasma to activated protein C (APC). This led us to examine the effect of fibrinogen $\gamma^{\prime}$ (peptide) on APC resistance in normal and FV Leiden plasma. The results of this study are described in Chapter 3, together with the effect of the fibrinogen $\gamma^{\prime}$ peptide on protein $C$ activation by thrombin/TM.

According to the revised model of coagulation, the first traces of thrombin formed during the initiation phase can activate FXI. However, thrombin-catalyzed FXI activation is extremely inefficient in vitro, suggesting the existence of a physiological cofactor that accelerates this reaction in vivo. In order to set up a model system to study the effect of the fibrinogen $\gamma^{\prime}$ peptide on FXI activation by thrombin, in Chapter 4 we analyse the role of $\mathrm{Na}^{+}$concentration, thrombin exosites and negatively charged surfaces in this reaction. Moreover, we determine the effect of the fibrinogen $\gamma^{\prime}$ peptide on FXI activation by thrombin. 
In Chapter 5 we present data on the effect of the fibrinogen $\gamma^{\prime}$ peptide on the thrombin-catalysed activation of FXIII and TAFI, the activated forms of which play an important role in fibrin cross-linking (FXIIla) and lysis (TAFla).

Chapter $\mathbf{6}$ is a general discussion of all results presented in this thesis and provides an integrated view of how the interaction with fibrinogen $\gamma^{\prime}$ modulates thrombin activity. 


\section{References}

1. Macfarlane RG. An Enzyme Cascade in the Blood Clotting Mechanism, and Its Function as a Biochemical Amplifier. Nature 1964; 202: p. 498-9.

2. Davie EW and Ratnoff OD. Waterfall Sequence for Intrinsic Blood Clotting. Science 1964; 145(3638): p. 1310-2.

3. Fleck RA, Rao LV, Rapaport SI and Varki N. Localization of human tissue factor antigen by immunostaining with monospecific, polyclonal anti-human tissue factor antibody. Thromb Res 1990; 59(2): p. 421-37.

4. Dahlback B. Blood coagulation. Lancet 2000; 355(9215): p. 1627-32.

5. Meijers JC, McMullen BA and Bouma BN. The contact activation proteins: a structure/function overview. Agents Actions Suppl 1992; 38 ( Pt 2): p. 219-30.

6. Mann KG, Brummel K and Butenas S. What is all that thrombin for? J Thromb Haemost 2003; 1(7): p. 1504-14.

7. Josso F and Prou-Wartelle O. Interaction of tissue factor and factor VII at the earliest phase of coagulation. Thromb Diath Haemorrh Suppl 1965; 17: p. 35-44.

8. Girard TJ, Warren LA, Novotny WF, Likert KM, Brown SG, Miletich JP and Broze GJ, Jr. Functional significance of the Kunitz-type inhibitory domains of lipoprotein-associated coagulation inhibitor. Nature 1989; 338(6215): p. 518-20.

9. Hackeng TM, Sere KM, Tans $G$ and Rosing J. Protein $S$ stimulates inhibition of the tissue factor pathway by tissue factor pathway inhibitor. Proc Natl Acad Sci U S A 2006; 103(9): p. 3106-11.

10. Peraramelli S, Thomassen S, Heinzmann A, Rosing J, Hackeng TM, Hartmann R, Scheiflinger $F$ and Dockal M. Inhibition of tissue factor:factor VIla-catalyzed factor IX and factor X activation by TFPI and TFPI constructs. J Thromb Haemost 2014; 12(11): p. 182637.

11. Dahlback B and Villoutreix BO. The anticoagulant protein C pathway. FEBS Lett 2005; 579(15): p. 3310-6.

12. van 't Veer $C$ and Mann KG. Regulation of tissue factor initiated thrombin generation by the stoichiometric inhibitors tissue factor pathway inhibitor, antithrombin-III, and heparin cofactor-II. J Biol Chem 1997; 272(7): p. 4367-77.

13. Royle NJ, Irwin DM, Koschinsky ML, MacGillivray RT and Hamerton JL. Human genes encoding prothrombin and ceruloplasmin map to $11 \mathrm{p} 11-\mathrm{q} 12$ and $3 \mathrm{q} 21-24$, respectively. Somat Cell Mol Genet 1987; 13(3): p. 285-92.

14. Heldebrant CM, Butkowski RJ, Bajaj SP and Mann KG. The activation of prothrombin. II. Partial reactions, physical and chemical characterization of the intermediates of activation. J Biol Chem 1973; 248(20): p. 7149-63.

15. Bode W, Turk D and Karshikov A. The refined 1.9-A X-ray crystal structure of D-Phe-ProArg chloromethylketone-inhibited human alpha-thrombin: structure analysis, overall structure, electrostatic properties, detailed active-site geometry, and structure-function relationships. Protein Sci 1992; 1(4): p. 426-71. 
16. Lane DA, Philippou $\mathrm{H}$ and Huntington JA. Directing thrombin. Blood 2005; 106(8): p. 260512.

17. Huntington JA. Molecular recognition mechanisms of thrombin. J Thromb Haemost 2005; 3(8): p. 1861-72.

18. Crawley JT, Zanardelli S, Chion CK and Lane DA. The central role of thrombin in hemostasis. J Thromb Haemost 2007; 5 Suppl 1: p. 95-101.

19. Vijayalakshmi J, Padmanabhan KP, Mann KG and Tulinsky A. The Isomorphous Structures of Prethrombin2, Hirugen-Thrombin, and Ppack-Thrombin - Changes Accompanying Activation and Exosite Binding to Thrombin. Protein Science 1994; 3(12): p. 2254-2271.

20. Di Cera E. Thrombin: a paradigm for enzymes allosterically activated by monovalent cations. C R Biol 2004; 327(12): p. 1065-76.

21. Pineda AO, Savvides SN, Waksman G and Di Cera E. Crystal structure of the anticoagulant slow form of thrombin. J Biol Chem 2002; 277(43): p. 40177-80.

22. Gruber A, Cantwell AM, Di Cera E and Hanson SR. The thrombin mutant W215A/E217A shows safe and potent anticoagulant and antithrombotic effects in vivo. J Biol Chem 2002; 277(31): p. 27581-4.

23. De Filippis V, De Dea E, Lucatello $F$ and Frasson R. Effect of $\mathrm{Na}$ + binding on the conformation, stability and molecular recognition properties of thrombin. Biochemical Journal 2005; 390: p. 485-492.

24. Lechtenberg BC, Freund SMV and Huntington JA. An ensemble view of thrombin allostery. Biological Chemistry 2012; 393(9): p. 889-898.

25. Coughlin SR. Protease-activated receptors in hemostasis, thrombosis and vascular biology. J Thromb Haemost 2005; 3(8): p. 1800-14.

26. De Candia E, Hall SW, Rutella S, Landolfi R, Andrews RK and De Cristofaro R. Binding of thrombin to glycoprotein $\mathrm{Ib}$ accelerates the hydrolysis of Par-1 on intact platelets. $J$ Biol Chem 2001; 276(7): p. 4692-8.

27. Brass LF. Thrombin and platelet activation. Chest 2003; 124(3 Suppl): p. 18S-25S.

28. Mosesson MW. Fibrinogen and fibrin structure and functions. J Thromb Haemost 2005; 3(8): p. 1894-904.

29. Segers K, Dahlback B, Bock PE, Tans G, Rosing J and Nicolaes GA. The role of thrombin exosites I and II in the activation of human coagulation factor V. J Biol Chem 2007; 282(47): p. 33915-24.

30. Esmon CT and Lollar P. Involvement of thrombin anion-binding exosites 1 and 2 in the activation of factor V and factor VIII. J Biol Chem 1996; 271(23): p. 13882-7.

31. Gailani D and Broze GJ, Jr. Effects of glycosaminoglycans on factor XI activation by thrombin. Blood Coagul Fibrinolysis 1993; 4(1): p. 15-20.

32. Muszbek L, Yee VC and Hevessy Z. Blood coagulation factor XIII: structure and function. Thromb Res 1999; 94(5): p. 271-305.

33. Bajzar L, Morser J and Nesheim M. TAFI, or plasma procarboxypeptidase B, couples the coagulation and fibrinolytic cascades through the thrombin-thrombomodulin complex. $J$ Biol Chem 1996; 271(28): p. 16603-8. 
34. Foley JH, Kim PY, Mutch NJ and Gils A. Insights into thrombin activatable fibrinolysis inhibitor function and regulation. J Thromb Haemost 2013; 11 Suppl 1: p. 306-15.

35. Huntington JA. Natural inhibitors of thrombin. Thromb Haemost 2014; 111(4): p. 583-9.

36. Enghild JJ, Salvesen G, Thogersen IB and Pizzo SV. Proteinase binding and inhibition by the monomeric alpha-macroglobulin rat alpha 1-inhibitor-3. J Biol Chem 1989; 264(19): p. 11428-35.

37. Barrett AJ and Starkey PM. The interaction of alpha 2-macroglobulin with proteinases. Characteristics and specificity of the reaction, and a hypothesis concerning its molecular mechanism. Biochem J 1973; 133(4): p. 709-24.

38. Kant JA, Fornace AJ, Jr., Saxe D, Simon MI, McBride OW and Crabtree GR. Evolution and organization of the fibrinogen locus on chromosome 4: gene duplication accompanied by transposition and inversion. Proc Natl Acad Sci U S A 1985; 82(8): p. 2344-8.

39. Blomback B, Hessel B, Hogg D and Therkildsen L. A two-step fibrinogen--fibrin transition in blood coagulation. Nature 1978; 275(5680): p. 501-5.

40. Mosesson MW, Siebenlist KR and Meh DA. The structure and biological features of fibrinogen and fibrin. Ann N Y Acad Sci 2001; 936: p. 11-30.

41. Ariëns RA. Fibrin(ogen) and thrombotic disease. J Thromb Haemost 2013; 11 Suppl 1: p. 294-305.

42. Cesarman-Maus G and Hajjar KA. Molecular mechanisms of fibrinolysis. Br J Haematol 2005; 129(3): p. 307-21.

43. Seegers $W H$, Nieft $M$ and Loomis EC. Note on the Adsorption of Thrombin on Fibrin. Science 1945; 101(2629): p. 520-1.

44. Lak M, Keihani M, Elahi F, Peyvandi F and Mannucci PM. Bleeding and thrombosis in 55 patients with inherited afibrinogenaemia. Br J Haematol 1999; 107(1): p. 204-6.

45. de Moerloose $\mathbf{P}$ and Neerman-Arbez M. Congenital fibrinogen disorders. Semin Thromb Hemost 2009; 35(4): p. 356-66.

46. van Hylckama Vlieg A and Rosendaal FR. High levels of fibrinogen are associated with the risk of deep venous thrombosis mainly in the elderly. J Thromb Haemost 2003; 1(12): p. 2677-8.

47. Vaýa A, Mira Y, Martinez M, Villa P, Ferrando F, Estelles A, Corella D and Aznar J. Biological risk factors for deep vein trombosis. Clin Hemorheol Microcirc 2002; 26(1): p. 41-53.

48. Koopman J, Haverkate F, Lord ST, Grimbergen J and Mannucci PM. Molecular basis of fibrinogen Naples associated with defective thrombin binding and thrombophilia. Homozygous substitution of B beta 68 Ala----Thr. J Clin Invest 1992; 90(1): p. 238-44.

49. Wilhelmsen L, Svardsudd K, Korsan-Bengtsen K, Larsson B, Welin L and Tibblin G. Fibrinogen as a risk factor for stroke and myocardial infarction. N Engl J Med 1984; 311(8): p. 501-5.

50. Danesh J, Lewington S, Thompson SG, Lowe GD, Collins R, Kostis JB, Wilson AC, Folsom AR, Wu K, Benderly M, Goldbourt U, Willeit J, Kiechl S, Yarnell JW, Sweetnam PM, Elwood PC, Cushman M, Psaty BM, Tracy RP, Tybjaerg-Hansen A, Haverkate F, de Maat MP, Fowkes FG, Lee AJ, Smith FB, Salomaa V, Harald K, Rasi R, Vahtera E, Jousilahti P, Pekkanen J, D'Agostino R, Kannel WB, Wilson PW, Tofler G, Arocha-Pinango CL, Rodriguez-Larralde A, 
Nagy E, Mijares M, Espinosa R, Rodriquez-Roa E, Ryder E, Diez-Ewald MP, Campos G, Fernandez V, Torres E, Marchioli R, Valagussa F, Rosengren A, Wilhelmsen L, Lappas G, Eriksson H, Cremer P, Nagel D, Curb JD, Rodriguez B, Yano K, Salonen JT, Nyyssonen K, Tuomainen TP, Hedblad B, Lind P, Loewel H, Koenig W, Meade TW, Cooper JA, De Stavola B, Knottenbelt C, Miller GJ, Cooper JA, Bauer KA, Rosenberg RD, Sato S, Kitamura A, Naito Y, Palosuo T, Ducimetiere P, Amouyel P, Arveiler D, Evans AE, Ferrieres J, Juhan-Vague I, Bingham A, Schulte H, Assmann G, Cantin B, Lamarche B, Despres JP, Dagenais GR, Tunstall-Pedoe H, Woodward M, Ben-Shlomo Y, Davey Smith G, Palmieri V, Yeh JL, Rudnicka A, Ridker P, Rodeghiero F, Tosetto A, Shepherd J, Ford I, Robertson M, Brunner E, Shipley M, Feskens EJ, Kromhout D, Dickinson A, Ireland B, Juzwishin K, Kaptoge S, Lewington S, Memon A, Sarwar N, Walker M, Wheeler J, White I and Wood A. Plasma fibrinogen level and the risk of major cardiovascular diseases and nonvascular mortality: an individual participant meta-analysis. JAMA 2005; 294(14): p. 1799-809.

51. Chung DW and Davie EW. Gamma and gamma' chains of human fibrinogen are produced by alternative mRNA processing. Biochemistry 1984; 23(18): p. 4232-6.

52. Wolfenstein-Todel $C$ and Mosesson MW. Carboxy-terminal amino acid sequence of a human fibrinogen gamma-chain variant (gamma'). Biochemistry 1981; 20(21): p. 6146-9.

53. Francis CW, Kraus DH and Marder VJ. Structural and chromatographic heterogeneity of normal plasma fibrinogen associated with the presence of three gamma-chain types with distinct molecular weights. Biochim Biophys Acta 1983; 744(2): p. 155-64.

54. Lovely RS, Moaddel M and Farrell DH. Fibrinogen gamma' chain binds thrombin exosite II. J Thromb Haemost 2003; 1(1): p. 124-31.

55. Fredenburgh JC, Stafford AR, Leslie BA and Weitz JI. Bivalent binding to gammaA/gamma'fibrin engages both exosites of thrombin and protects it from inhibition by the antithrombin-heparin complex. J Biol Chem 2008; 283(5): p. 2470-7.

56. Meh DA, Siebenlist KR, Brennan SO, Holyst $T$ and Mosesson MW. The amino acid sequence in fibrin responsible for high affinity thrombin binding. Thromb Haemost 2001; 85(3): p. 470-4.

57. Lovely RS, Boshkov LK, Marzec UM, Hanson SR and Farrell DH. Fibrinogen gamma' chain carboxy terminal peptide selectively inhibits the intrinsic coagulation pathway. $\mathrm{Br} J$ Haematol 2007; 139(3): p. 494-503.

58. Lovely RS, Rein CM, White TC, Jouihan SA, Boshkov LK, Bakke AC, McCarty OJ and Farrell $\mathrm{DH}$. gammaA/gamma' fibrinogen inhibits thrombin-induced platelet aggregation. Thromb Haemost 2008; 100(5): p. 837-46.

59. Lancellotti S, Rutella S, De Filippis V, Pozzi N, Rocca B and De Cristofaro R. Fibrinogenelongated gamma chain inhibits thrombin-induced platelet response, hindering the interaction with different receptors. J Biol Chem 2008; 283(44): p. 30193-204.

60. Mosesson MW. Update on antithrombin I (fibrin). Thromb Haemost 2007; 98(1): p. 105-8.

61. Mosesson MW and Finlayson JS. Biochemical and chromatographic studies of certain activities associated with human fibrinogen preparations. J Clin Invest 1963; 42: p. 747-55.

62. Siebenlist KR, Meh DA and Mosesson MW. Plasma factor XIII binds specifically to fibrinogen molecules containing gamma chains. Biochemistry 1996; 35(32): p. 10448-53. 
63. Uitte de Willige $\mathrm{S}$, Standeven KF, Philippou $\mathrm{H}$ and Ariëns RA. The pleiotropic role of the fibrinogen gamma' chain in hemostasis. Blood 2009; 114(19): p. 3994-4001.

64. Allan P, Uitte de Willige $S$, Abou-Saleh RH, Connell SD and Ariëns RA. Evidence that fibrinogen gamma' directly interferes with protofibril growth: implications for fibrin structure and clot stiffness. J Thromb Haemost 2012; 10(6): p. 1072-80.

65. Cooper AV, Standeven KF and Ariens RA. Fibrinogen gamma-chain splice variant gamma' alters fibrin formation and structure. Blood 2003; 102(2): p. 535-40.

66. Falls LA and Farrell DH. Resistance of gammaA/gamma' fibrin clots to fibrinolysis. J Biol Chem 1997; 272(22): p. 14251-6.

67. Collet JP, Nagaswami C, Farrell DH, Montalescot $G$ and Weisel JW. Influence of gamma' fibrinogen splice variant on fibrin physical properties and fibrinolysis rate. Arterioscler Thromb Vasc Biol 2004; 24(2): p. 382-6.

68. Uitte de Willige $\mathrm{S}$, de Visser MC, Houwing-Duistermaat JJ, Rosendaal FR, Vos HL and Bertina RM. Genetic variation in the fibrinogen gamma gene increases the risk for deep venous thrombosis by reducing plasma fibrinogen gamma' levels. Blood 2005; 106(13): p. 4176-83.

69. Nowak-Gottl U, Weiler H, Hernandez I, Thedieck S, Seehafer T, Schulte T and Stoll M. Fibrinogen alpha and gamma genes and factor VLeiden in children with thromboembolism: results from 2 family-based association studies. Blood 2009; 114(9): p. 1947-53.

70. El-Galaly TC, Severinsen MT, Overvad K, Steffensen R, Vistisen AK, Tjonneland A and Kristensen SR. Single nucleotide polymorphisms and the risk of venous thrombosis: results from a Danish case-cohort study. Br J Haematol 2013; 160(6): p. 838-41.

71. Smalberg JH, Koehler E, Darwish Murad S, Plessier A, Seijo S, Trebicka J, Primignani M, Rijken DC, de Maat MP, Garcia-Pagan JC, Valla DC, Janssen HL, Leebeek FW and European Network for Vascular Disorders of the L. Fibrinogen gamma' and variation in fibrinogen gamma genes in the etiology of portal vein thrombosis. Thromb Haemost 2013; 109(3): p. 558-60.

72. Drouet L, Paolucci F, Pasqualini N, Laprade M, Ripoll L, Mazoyer E, Bal dit Sollier C and Vanhove N. Plasma gamma'/gamma fibrinogen ratio, a marker of arterial thrombotic activity: a new potential cardiovascular risk factor? Blood Coagul Fibrinolysis 1999; 10 Suppl 1: p. S35-9.

73. Lovely RS, Falls LA, Al-Mondhiry HA, Chambers CE, Sexton GJ, Ni H and Farrell DH. Association of gammaA/gamma' fibrinogen levels and coronary artery disease. Thromb Haemost 2002; 88(1): p. 26-31.

74. Appiah D, Schreiner PJ, MacLehose RF and Folsom AR. Association of Plasma gamma' Fibrinogen With Incident Cardiovascular Disease: The Atherosclerosis Risk in Communities (ARIC) Study. Arterioscler Thromb Vasc Biol 2015.

75. Rein-Smith CM, Anderson NW and Farrell DH. Differential regulation of fibrinogen gamma chain splice isoforms by interleukin-6. Thromb Res 2013; 131(1): p. 89-93. 
76. Walton BL, Getz TM, Bergmeier W, Lin FC, Uitte de Willige $S$ and Wolberg AS. The fibrinogen gammaA/gamma' isoform does not promote acute arterial thrombosis in mice. J Thromb Haemost 2014; 12(5): p. 680-9.

77. Hemker HC, Giesen P, AIDieri R, Regnault V, de Smed E, Wagenvoord R, Lecompte T and Beguin S. The calibrated automated thrombogram (CAT): a universal routine test for hyper- and hypocoagulability. Pathophysiol Haemost Thromb 2002; 32(5-6): p. 249-53.

78. Hemker HC, Al Dieri R, De Smedt E and Beguin S. Thrombin generation, a function test of the haemostatic-thrombotic system. Thromb Haemost 2006; 96(5): p. 553-61.

79. Castoldi E and Rosing J. Thrombin generation tests. Thromb Res 2011; 127 Suppl 3: p. S215.

80. Hemker HC, Giesen PL, Ramjee M, Wagenvoord R and Beguin S. The thrombogram: monitoring thrombin generation in platelet-rich plasma. Thromb Haemost 2000; 83(4): p. 589-91. 



\section{Chapter 2}

Inhibition of thrombin-mediated factor $\mathbf{V}$ activation

contributes to the anticoagulant activity of

fibrinogen $\gamma^{\prime}$

Farida Omarova, Shirley Uitte de Willige, Robert A. S. Ariëns, Jan Rosing, Rogier M. Bertina, Elisabetta Castoldi

J Thromb Haemost. 2013; 11:1669-78 


\begin{abstract}
Background. Besides its role in blood clotting, fibrinogen exerts a poorly understood anticoagulant function by binding thrombin and modulating its activity. In particular, the $\gamma \mathrm{A} / \gamma^{\prime}$ fibrinogen isoform binds with high affinity to thrombin exosite II through the anionic C-terminal end of the $\gamma^{\prime}$ chain. This interaction down-regulates thrombinmediated factor VIII (FVIII) activation, but its effect on factor V (FV) activation is unknown. Objectives. To investigate the overall anticoagulant activity of fibrinogen and particularly of fibrinogen $\gamma^{\prime}$ in plasma, and to verify whether the fibrinogen $\gamma^{\prime}$ Cterminal peptide affects thrombin-mediated FV activation. Methods. Thrombin generation was measured by Calibrated Automated Thrombography in whole and defibrinated plasma and in plasma supplemented with the (sulfated) fibrinogen $\gamma^{\prime} \mathrm{C}$ terminal peptide $(0-500 \mu \mathrm{M})$. The effect of the peptide on thrombin-mediated FV activation was studied in model systems and in plasma. Results. Total fibrinogen prolonged the lag time of thrombin generation at low tissue factor concentrations. The fibrinogen $\gamma^{\prime}$ peptide dose-dependently prolonged the lag time and decreased the peak height of thrombin generation at low TF, whereas a scrambled control peptide was ineffective. These effects persisted in the presence of an anti-FVIII antibody, suggesting that the peptide may also inhibit thrombin-mediated activation of FV. This was confirmed in model systems and in plasma. Conclusions. Total fibrinogen and the fibrinogen $\gamma^{\prime}$ peptide have an overall anticoagulant effect on thrombin generation determined at low TF. Inhibition of thrombin-mediated FV activation by the fibrinogen $\gamma^{\prime}$ peptide is a novel mechanism of the anticoagulant activity of fibrinogen $\gamma^{\prime}$.
\end{abstract}




\section{Introduction}

Fibrinogen is a large plasma glycoprotein consisting of a double set of three polypeptide chains: $A \alpha, B \beta$ and $\gamma$, each encoded by a different gene ( $F G A, F G B, F G G)$ [1]. Alternative processing of the FGG pre-mRNA generates two polypeptide chains $\left(\gamma \mathrm{A}\right.$ and $\left.\gamma^{\prime}\right)$ that differ in their C-terminal ends [2]. The more abundant $\gamma \mathrm{A}$ isoform consists of 411 amino acids. The minor $\gamma^{\prime}$ isoform comprises 427 amino acids, the four last residues of the $\gamma \mathrm{A}$ chain being replaced by a highly anionic 20-amino-acid sequence containing seven acidic residues and two sulfated tyrosines [3]. Random pairing of the $\gamma$ chain isoforms produces three types of fibrinogen molecules: $\gamma \mathrm{A} / \gamma \mathrm{A}$ (85-90\% of total plasma fibrinogen), $\gamma \mathrm{A} / \gamma^{\prime}(10-15 \%)$ and $\gamma^{\prime} / \gamma^{\prime}(<1 \%)[3,4]$.

Apart from being the precursor of fibrin and from promoting platelet aggregation [5], fibrin(ogen) also has less understood anticoagulant properties ("antithrombin I" activity [6]) related to its ability to "adsorb" thrombin and modulate its activity. Thrombin, the key enzyme in hemostasis, converts fibrinogen to fibrin and activates coagulation factors (F) V, VIII, XI and XIII, as well as platelets. The interaction of thrombin with its substrates is mediated by two anion-binding exosites, i.e. positively charged sites distinct from the active site, which play a major role in the allosteric regulation of thrombin activity [7]. Fibrin(ogen) binds thrombin via multiple interactions involving not only the active site, but also both exosites of thrombin. The interaction with exosite I is mediated by low-affinity binding sites located near the amino terminal ends of the $A \alpha$ and $B \beta$ chains of fibrinogen, whereas the interaction with exosite II is mediated by a high-affinity binding site located in the C-terminal end of the fibrinogen $\gamma^{\prime}$ isoform (residues $A^{414}-L^{427}$ ) $[8,9]$ and is enhanced by sulfation of residues $Y^{418}$ and $Y^{422}$ [8-10]. Binding of the fibrinogen $\gamma^{\prime}$ chain to thrombin exosite II has been reported to impair thrombin-mediated factor VIII (FVIII) activation [11] and platelet aggregation [12,13]. Although these effects likely contribute to the anticoagulant activity of fibrinogen $\gamma^{\prime}$, additional effects on other thrombin substrates cannot be excluded. In particular, since FV is structurally homologous to FVIII [14] and its full activation requires both thrombin exosites [15], engagement of exosite II by fibrinogen $\gamma^{\prime}$ may also interfere with FV activation by thrombin.

The pathophysiological relevance of the anticoagulant action of fibrinogen in general and fibrinogen $\gamma^{\prime}$ in particular is supported by: 1) the observation that fibrinogendeficient patients may experience thrombotic as well as bleeding complications 
$[16,17] ; 2)$ the risk of venous thrombosis associated with the common FGG-H2 haplotype [18-20], which predicts reduced levels of the fibrinogen $\gamma \mathrm{A} / \gamma^{\prime}$ isoform [18]; 3 ) the protective effect of the fibrinogen $\gamma^{\prime}$ C-terminal peptide in a baboon thrombosis model [11]; and 4) the ability of the human fibrinogen $\gamma^{\prime}$ chain to reduce thrombus size in FV Leiden mice exposed to a prothrombotic stimulus [21]. On the other hand, it has been reported that fibrin-bound thrombin is still catalytically active [22] and simultaneously protected from inhibition by the antithrombin/heparin complex [23], thus challenging the anticoagulant role of the interaction of thrombin with fibrin(ogen).

The aim of our study was to investigate the overall effect of fibrinogen and particularly fibrinogen $\gamma^{\prime}$ on thrombin generation and activity in plasma. To this end, we employed the thrombin generation assay [24,25], a global assay that uses a fluorogenic substrate to monitor the formation and inhibition of thrombin after initiation of coagulation with tissue factor (TF). A synthetic peptide was used as a model for the C-terminal end of the fibrinogen $\gamma^{\prime}$, which binds to thrombin exosite II. Moreover, we specifically studied the effect of the fibrinogen $\gamma^{\prime}$ peptide on thrombinmediated FV activation.

\section{Materials and methods}

\section{Fibrinogen $\gamma^{\prime}$ peptides}

Synthetic 20-amino-acid peptides with the same sequence as the fibrinogen $\gamma^{\prime}$ chain C-terminal end, with or without sulfate or phosphate groups on $\mathrm{Y}^{418}$ and $\mathrm{Y}^{422}$ (Table 2.1), were obtained from Pepscan (Lelystad, the Netherlands). A doubly sulfated scrambled peptide (Table 2.1) was designed as a negative control. Peptides were synthesized on a PTI Symphony peptide synthesizer using standard Solid Phase Fmocchemistry. Crude peptides were purified by reverse-phase HPLC and were $>95 \%$ pure as judged by absorbance at $215 \mathrm{~nm}$ using UPLC. The molecular mass was confirmed by electrospray-MS. Lyophilised peptides were resuspended in Hepes-buffered saline (25 mM Hepes, $175 \mathrm{mM} \mathrm{NaCl}$, pH 7.7 at room temperature) and stored in aliquots at $-80^{\circ} \mathrm{C}$. All peptides were freely soluble in aqueous buffers and concentrations of peptide solutions were determined based on peptide mass. 


\section{Blood collection and plasma preparation}

A normal plasma pool was prepared by pooling plasma from 22 healthy volunteers free of medication ( 15 males and 7 females, mean age 30.2 years). Venous blood was collected in $1 / 10$ volume of $0.109 \mathrm{M}$ trisodium citrate and platelet-free plasma was obtained by centrifugation at $\sim 3000 \mathrm{~g}$ for 10 minutes followed by centrifugation at $10000 \mathrm{~g}$ for 10 minutes. Plasma was snap-frozen in small aliquots and stored at $-80^{\circ} \mathrm{C}$.

\section{Measurement of thrombin generation}

Thrombin generation in platelet-free plasma was determined using Calibrated Automated Thrombography (CAT) [24]. Coagulation was initiated with various concentrations of recombinant TF (Dade Innovin, Marburg, Germany), $30 \mu \mathrm{M}$ phospholipid vesicles (1,2-dioleoyl-sn-glycero-3-phosphoserine(DOPS)/1,2-dioleoyl-snglycero-3-phosphatidylcholine(DOPC)/1,2-dioleoyl-sn-glycero-3-

phosphoethanolamine (DOPE), 20/60/20, $\mathrm{mol} / \mathrm{mol} / \mathrm{mol}$ ) and $12 \mathrm{mM} \mathrm{CaCl}$. Thrombin activity in plasma was monitored continuously at $37^{\circ} \mathrm{C}$ employing the low-affinity fluorogenic substrate Z-Gly-Gly-Arg-AMC (I-1140; BACHEM, Bubendorf, Switzerland). In separate wells, $100 \mathrm{nM}$ thrombin calibrator (Thrombinoscope, Maastricht, the Netherlands) was added to plasma to obtain a calibration curve for the conversion of fluorescence into thrombin concentration. Fluorescence was read in a Fluoroskan Ascent reader (Thermo Labsystems, Helsinki, Finland) equipped with a 390/460 filter set and thrombin generation curves were calculated with the Thrombinoscope software (Thrombinoscope). Among all parameters that describe the thrombin generation curve, lag time and peak height were used for subsequent analyses.

Each thrombin generation reaction contained $80 \mu$ of normal pool plasma in a total volume of $125 \mu \mathrm{l}$. To prevent contact activation, all samples were measured in the presence of $44 \mu \mathrm{g} / \mathrm{ml}$ corn trypsin inhibitor (Hematologic Technologies, Essex Junction, VT, USA). In some experiments, plasma was defibrinated prior to the thrombin generation measurement by incubation with $1.17 \mathrm{U} / \mathrm{ml}$ Ancrod (NIBSC, Potters Bar, Hertfordshire, UK) for 10 minutes at $37^{\circ} \mathrm{C}$ and subsequent removal of the fibrin clot with a spatula.

In the experiments with fibrinogen $\gamma^{\prime}$ chain peptides, coagulation was initiated with 2 or $10 \mathrm{pM}$ TF in whole plasma in the presence of various concentrations (0-500 $\mu \mathrm{M})$ of peptide. Control experiments with the WT-S12 peptide showed that this peptide 
$(500 \mu \mathrm{M})$ does not affect the conversion of fluorogenic substrate by thrombin $(0.5 \mathrm{nM})$ or by the thrombin calibrator $(100 \mathrm{nM})$.

To prevent coagulation factors VIII and XI from contributing to thrombin generation, in some experiments saturating concentrations of anti-human FVIII heat-treated goat serum (kind gift of Baxter Healthcare $\mathrm{GmbH}$, Vienna, Austria) or monoclonal antifactor XI (FXI) antibody (Hematologic Technologies) were added to plasma. The antibody concentrations were chosen such as to completely abolish intrinsically triggered thrombin generation in control experiments.

\section{Factor $\mathrm{V}$ activation assays}

\section{FV activation in model system}

FV activation by thrombin in the absence and presence of fibrinogen $\gamma^{\prime}$ peptides was followed in time, essentially as described [26]. Briefly, purified human FV (Hematologic Technologies) was diluted in $25 \mathrm{mM} \mathrm{Hepes,} 140 \mathrm{mM} \mathrm{NaCl}, 5 \mathrm{mM} \mathrm{CaCl}$, $\mathrm{pH} 7.7$ and $5 \mathrm{mg} / \mathrm{ml}$ bovine serum albumin (BSA), and activated with $0.5 \mathrm{nM}$ thrombin (Hematologic Technologies) in the presence of varying concentrations (0-500 $\mu \mathrm{M})$ of WT-S12 or SCR-S12 fibrinogen $\gamma^{\prime}$ peptide. At regular time points subsamples were drawn from the activation mixture, diluted in a solution containing $30 \mathrm{mM} \mathrm{CaCl}_{2}$ and $1 \mu \mathrm{M}$ Pefabloc TH (Pentapharm Ltd, Basel, Switzerland), and assayed for FVa activity in a prothrombinase reaction mixture containing $0.5 \mathrm{nM}$ bovine factor $\mathrm{Xa}$ ( $\mathrm{FXa}$, purified in house), $0.5 \mu \mathrm{M}$ human prothrombin (Enzyme Research Laboratories, South Bend, IN, USA), $20 \mu \mathrm{M}$ phospholipid vesicles (10\% brain phosphatidylserine, $90 \%$ egg yolk phosphatidylcholine, $\mathrm{mol} / \mathrm{mol}$ ) and $1 \mu \mathrm{M}$ Pefabloc $\mathrm{TH}$, to prevent feedback activation of $\mathrm{FV}$ by thrombin during the assay. After 1 minute, prothrombin activation was stopped by subsampling into ice-cold EDTA-buffer (50 mM Tris, $175 \mathrm{mM} \mathrm{NaCl}, 20 \mathrm{mM}$ EDTA, $0.5 \mathrm{mg} / \mathrm{ml}$ ovalbumin, $\mathrm{pH} 7.9$ at room temperature). Formed thrombin was quantified spectrophotometrically with chromogenic substrate S2238 (Chromogenix, Milan, Italy). The concentration of FV in the activation mixture was calculated from the rate of prothrombin activation using the turnover number $6000 \mathrm{~mol}$ of prothrombin activated per minute by 1 mol of FXa-FVa complex. All experiments were carried out in duplicate and averages are shown. Time-courses of FV activation were fitted to a single exponential equation using non-linear least-squares analysis. Initial rates of FV activation were plotted against peptide concentration and fitted to the 
equation of a rectangular hyperbola, from which half-maximal inhibitory concentrations $\left(\mathrm{IC}_{50}\right)$ for the WT-S12 and SCR-S12 peptides were calculated.

\section{Western blot analysis of FV activation}

Purified FV (20 nM in 25 mM Hepes, $140 \mathrm{mM} \mathrm{NaCl}, 5 \mathrm{mM} \mathrm{CaCl}$, pH 7.7, $0.5 \mathrm{mg} / \mathrm{ml}$ BSA) was activated with $0.5 \mathrm{nM}$ thrombin in the absence and presence of $500 \mu \mathrm{M}$ WTS12 peptide. At regular time points aliquots were drawn from the activation mixture into $1 / 5$ volume of sample buffer ( $40 \mathrm{mM}$ Tris, $3.3 \%$ sodium dodecyl sulfate (SDS), $50 \%$ glycerol, $6.25 \%$ mercaptoethanol, pH 6.7). Samples were denatured for 5 minutes at $96{ }^{\circ} \mathrm{C}$ and run on a $4-15 \%$ pre-cast polyacrylamide gel (Bio-Rad Laboratories, Veenendaal, the Netherlands) under reducing conditions. Proteins were then transferred to a polyvinylidene fluoride membrane by semi-dry blotting. Membranes were blocked for 30 min at $4{ }^{\circ} \mathrm{C}$ with $5 \%$ skim milk (Merck, Darmstadt, Germany) in 25 $\mathrm{mM}$ Hepes, $150 \mathrm{mM} \mathrm{NaCl}$, pH 7.7, washed three times with phosphate buffered saline (PBS)/ 0.3\% Tween 20 (Merck)/ $1 \mathrm{mg} / \mathrm{ml} \mathrm{BSA}$, and incubated for 2 hours at room temperature (RT) with a monoclonal antibody directed against the FV heavy chain (AHV-5146, Hematologic Technologies, $5 \mu \mathrm{g} / \mathrm{ml}$ in wash buffer). Subsequently, membranes were washed three times and incubated with a horseradish peroxidase (HRP)-labeled rabbit anti-mouse antibody (Dako, Glostrup, Denmark, 1:1000 in wash buffer) for 1 hour at RT. After three additional washes, membranes were developed using $50 \mathrm{mM}$ Tris and $1 \mathrm{mg} / \mathrm{ml}$ diaminobenzidine (Sigma-Aldrich, Zwijndrecht, the Netherlands), pH 7.5.

\section{FV generation in plasma}

To study the inhibitory effect of fibrinogen $\gamma^{\prime}$ peptides on FV activation in plasma, normal pooled plasma was defibrinated with Ancrod as described above. Coagulation was initiated with $2 \mathrm{pM} \mathrm{TF}, 30 \mu \mathrm{M}$ phospholipid vesicles (DOPS/DOPC/DOPE, $20 / 60 / 20 \mathrm{~mol} / \mathrm{mol} / \mathrm{mol}$ ) and $12 \mathrm{mM} \mathrm{CaCl}_{2}$ at different concentrations (0-500 $\mu \mathrm{M}$ ) of WT-S12 or SCR-S12 peptide (final concentrations) in the presence of an anti-FVIII antibody (to prevent FVIIla from contributing to FV activation via intrinsically formed FXa). At regular time points subsamples were taken and FVa was quantified as described above. 


\section{Results}

\section{Thrombin generation in whole and defibrinated plasma}

The effect of fibrinogen on thrombin generation in plasma was studied by comparing

whole and defibrinated normal plasma. When coagulation was initiated with low TF concentrations $(\leq 0.5 \mathrm{pM})$, a condition at which both the extrinsic and intrinsic pathway of coagulation contribute to thrombin generation, the lag time of thrombin generation was markedly prolonged in whole plasma compared to defibrinated plasma (28.8 minutes vs. 15.1 minutes at $0.25 \mathrm{pM}$ TF and 13.6 minutes vs. 7.3 minutes at $0.5 \mathrm{pM}$ TF) (Figure 2.1A and 2.1B), suggesting that total fibrinogen has anticoagulant properties. However, the peak height of thrombin generation was similar in both plasmas. At higher TF concentrations the difference in lag time between whole and defibrinated plasma was abolished (Figure. 2.1C and 2.1D).
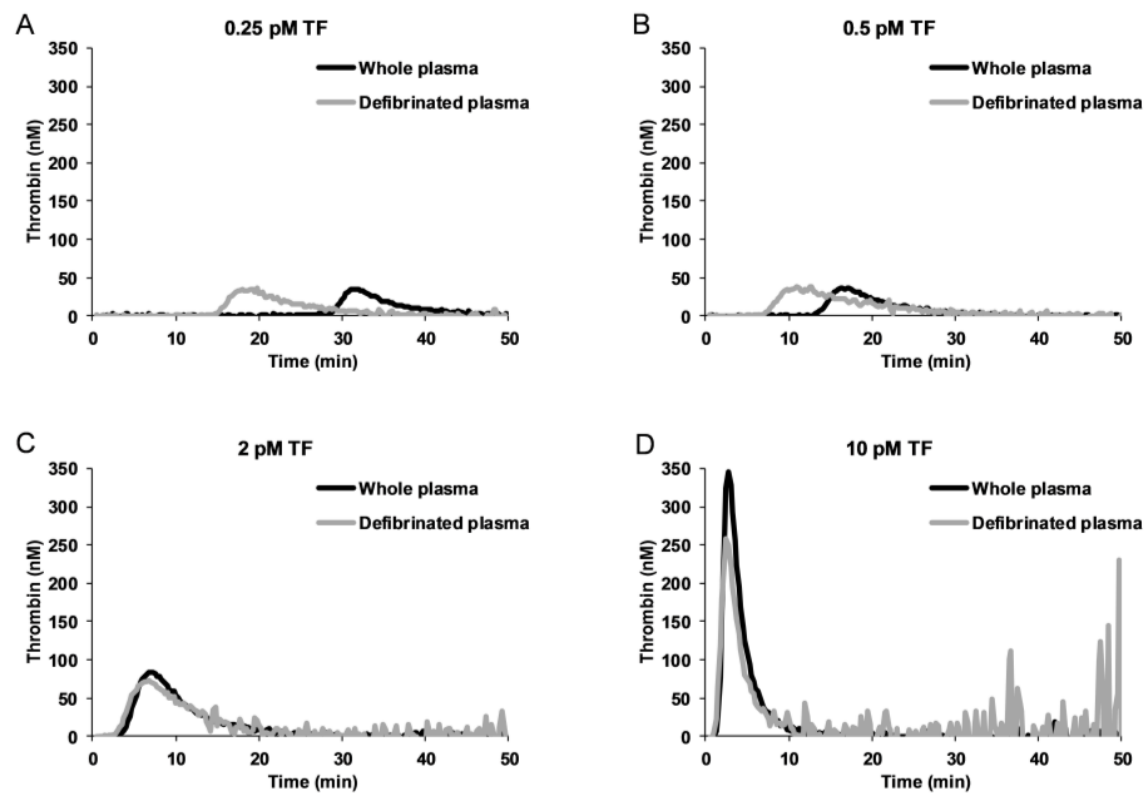

Figure 2.1 Effect of total fibrinogen on thrombin generation in normal plasma. Thrombin generation was measured in whole and defibrinated normal plasma after activation of coagulation with 0.25 (A), 0.5 (B), 2 (C) and 10 pM (D) TF. Averages of duplicate experiments are shown. 


\section{Effect of fibrinogen $\gamma^{\prime}$ peptides on thrombin generation}

To investigate whether the interaction between the C-terminal end of the fibrinogen $\gamma^{\prime}$ chain and thrombin contributes to the anticoagulant effect of fibrinogen, thrombin generation was measured at $2 \mathrm{pM}$ TF in the absence and presence of the fibrinogen $\gamma^{\prime}$ chain C-terminal peptide $(250 \mu \mathrm{M})$. Several variants of this peptide, with different modifications of $Y^{418}$ and $Y^{422}$, were tested: no tyrosine modified (WT), monosulfated at $\mathrm{Y}^{418}$ (WT-S1) or $\mathrm{Y}^{422}$ (WT-S2), doubly sulfated (WT-S12) and doubly phosphorylated (WT-P12) (Table 2.1). While the WT peptide had a minimal effect on thrombin generation, WT-S12 markedly prolonged the lag time and decreased the peak height of the thrombin generation curve. WT-S1 had an intermediate effect, whereas WT-S2 increased the peak height (Figure 2.2A). The WT-P12 peptide had a minor effect compared to WT-S12 (Figure 2.2B), underscoring the importance of sulfation (as opposed to phosphorylation) of both tyrosine residues for optimal thrombin inhibition. Therefore, the WT-S12 peptide was used in all subsequent experiments.

Table 2.1 Fibrinogen $\gamma^{\prime}$ peptides.

\begin{tabular}{|c|c|c|}
\hline Description & Code & Sequence \\
\hline Wild-type peptide, no modifications & WT & AC-VRPEHPAETEYDSLYPEDDL-OH \\
\hline $\begin{array}{l}\text { Wild-type peptide sulfated on the first } \\
\text { tyrosine residue }\end{array}$ & WT-S1 & Ac-VRPEHPAETEYYDSLYPEDDL-OH \\
\hline $\begin{array}{l}\text { Wild-type peptide sulfated on the } \\
\text { second tyrosine residue }\end{array}$ & WT-S2 & Ac-VRPEHPAETEYDSLYYPEDDL-OH \\
\hline $\begin{array}{l}\text { Wild-type peptide sulfated on both } \\
\text { tyrosine residues }\end{array}$ & WT-S12 & Ac-VRPEHPAETEY YDSLYYPEDDL-OH \\
\hline $\begin{array}{l}\text { Wild-type peptide phosphorylated on } \\
\text { both tyrosine residues }\end{array}$ & WT-P12 & Ac-VRPEHPAETEYDSLYPEDDL-OH \\
\hline $\begin{array}{l}\text { Scrambled peptide sulfated on both } \\
\text { tyrosine residues (negative control) }\end{array}$ & SCR-S12 & Ac-DESELDAY्YTPLPRPVEDH白-OH \\
\hline
\end{tabular}

$\mathrm{Y}=$ tyrosine, $\underline{\mathbf{Y}}=$ sulfated tyrosine, $\boldsymbol{Y}=$ phosphorylated tyrosine. 

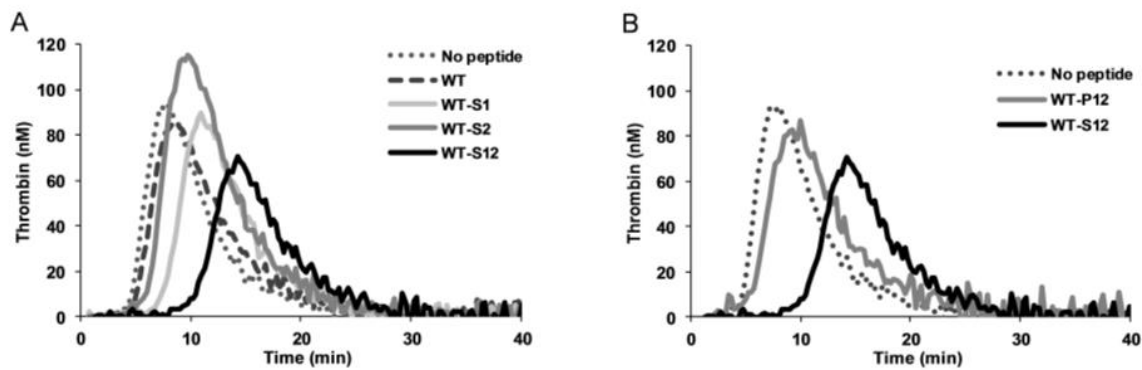

Figure 2.2 Effect of fibrinogen $\gamma^{\prime}$ peptides with different tyrosine modifications on thrombin generation. Thrombin generation was initiated in (whole) normal plasma with $2 \mathrm{pM}$ TF in the absence or presence of $250 \mu \mathrm{M}$ fibrinogen $\gamma^{\prime}$ peptides. A, comparison of different fibrinogen $\gamma^{\prime}$ peptides: wild-type without modifications (WT), sulfated on the first tyrosine (WT-S1), sulfated on the second tyrosine (WT-S2) or sulfated on both tyrosines (WT-S12). B, comparison of doubly phosphorylated (WT-P12) and doubly sulfated (WT-S12) peptides on thrombin generation. Averages of duplicate experiments are shown.

To verify the specificity of the effect of the fibrinogen $\gamma^{\prime}$ peptide, the WT-S12 peptide was compared to a doubly sulfated scrambled control peptide (SCR-S12). Thrombin generation was initiated with 2 or $10 \mathrm{pM}$ TF in the presence of increasing concentrations $(0-500 \mu \mathrm{M})$ of either peptide. At 2 pM TF the WT-S12 peptide effectively inhibited thrombin generation, prolonging the lag time and decreasing the peak height in a dose-dependent manner (Figure 2.3A), while SCR-S12 had virtually no effect (Figure 2.3B). At a higher TF concentration (10 pM) neither WT-S12 nor SCR-S12 had an effect on thrombin generation (Figure 2.3C and 2.3D). 

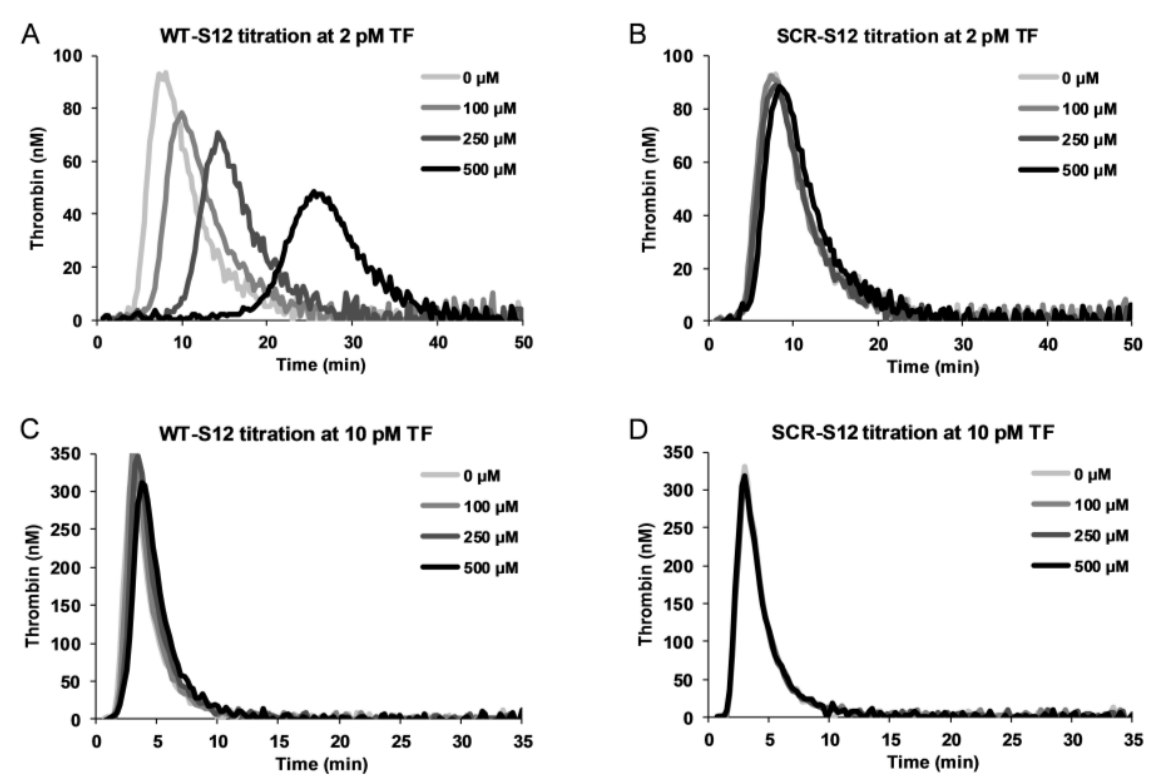

Figure 2.3 Effect of fibrinogen $\gamma^{\prime}$ peptides on thrombin generation. Thrombin generation was initiated in (whole) normal plasma with 2 pM TF (A, B) or 10 pM TF (C, D) in the presence of 0-500 $\mu \mathrm{M}$ fibrinogen $\gamma^{\prime}$ doubly sulfated wild-type (WT-S12) or scrambled (SCR-S12) peptide. Averages of duplicate experiments are shown.

Role of FVIII and FXI in the anticoagulant effect of the fibrinogen $\gamma^{\prime}$ peptides

To gain more insight into the functions of thrombin that are impaired by the interaction with the fibrinogen $\gamma^{\prime}$ peptide, we used anti-FXI and anti-FVIII antibodies to selectively exclude sections of the intrinsic pathway. Addition of these antibodies decreased thrombin generation in all conditions (Figure 2.4), confirming that at low TF concentration (2 pM) FXIa and FVIIla contribute to thrombin generation. Intriguingly, however, even in the presence of anti-FXI or anti-FVIII antibodies, the WT-S12 peptide still prolonged the lag time and decreased the peak height of thrombin generation (Figure 2.4B and 2.4C), suggesting that the $\gamma^{\prime}$ peptide not only inhibits the activation of FVIII, but also the activation of FV. 

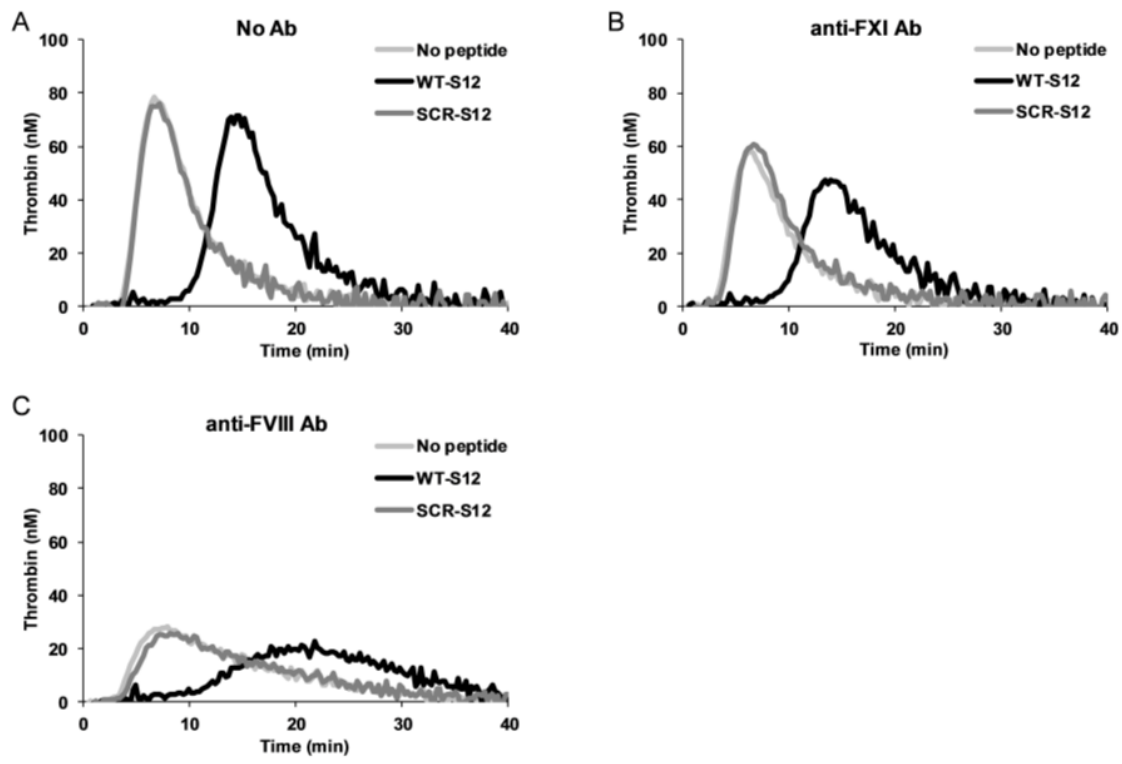

Figure 2.4 Effect of fibrinogen $\gamma^{\prime}$ peptides on thrombin generation in the presence of antiFXI and anti-FVIII antibodies. Thrombin generation was initiated in (whole) normal plasma with $2 \mathrm{pM}$ TF. Measurements were performed without peptides and with $250 \mu \mathrm{M}$ of fibrinogen $\gamma^{\prime}$ doubly sulfated wild-type (WT-S12) or scrambled (SCR-S12) peptide, in the absence (A) or presence of anti-FXI (B) and anti-FVIII (C) antibodies.

\section{Effect of fibrinogen $\gamma^{\prime}$ peptides on FV activation}

Purified FV was activated with thrombin in the presence of varying concentrations of WT-S12 or SCR-S12 peptide, and FVa was quantified at regular intervals in a prothrombinase-based assay. The WT-S12 peptide inhibited thrombin-mediated FV activation in a dose-dependent manner (Figure 2.5A), whereas the SCR-S12 peptide had only a minor inhibitory effect (Figure 2.5B). When initial rates of FV activation were plotted as a function of peptide concentration (Figure $2.5 \mathrm{C}$ ), the $\mathrm{IC}_{50}$ was found to be $27 \mu \mathrm{M}$ for the WT-S12 peptide and $325 \mu \mathrm{M}$ for the SCR-S12, indicating that the WT-S12 peptide is at least 10 times more effective than the SCR-S12 peptide in inhibiting thrombin-mediated FV activation. 

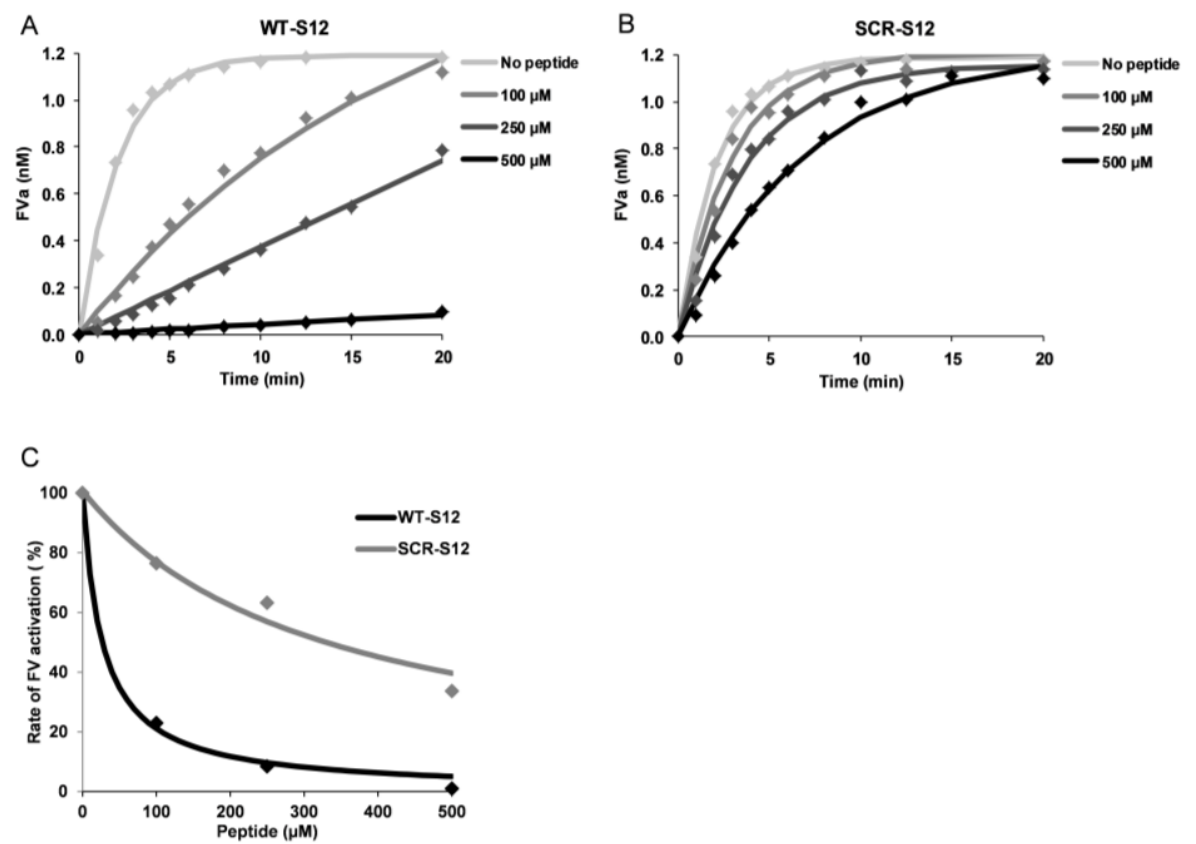

Figure 2.5 Effect of fibrinogen $\gamma^{\prime}$ peptides on thrombin-mediated FV activation in model system. Purified FV was activated with thrombin $(0.5 \mathrm{nM})$ in the presence of 0-500 $\mu \mathrm{M}$ fibrinogen $\gamma^{\prime}$ doubly sulfated wild-type (WT-S12) (A) or scrambled (SCR-S12) (B) peptide. At regular time points subsamples were taken from the activation mix and assayed for FVa activity in a prothrombinase-based assay. Time-courses of FV activation were fitted to a single exponential curve and initial rates of FV activation were plotted as a function of peptide concentration (C).

To prove that the WT-S12 peptide actually impairs the cleavage of FV by thrombin, we also followed the time-course of thrombin-mediated FV activation in the absence or presence of $500 \mu \mathrm{M}$ WT-S12 by SDS-PAGE and Western blotting. In the absence of peptide, FV was rapidly cleaved by thrombin, as demonstrated by the progressive disappearance of the single-chain FV (330 kDa) band and the parallel appearance of the FV heavy chain (105 kDa) band (Figure 2.6A). In contrast, hardly any cleavage of single-chain FV was observed in the presence of the WT-S12 peptide, with only traces of heavy chain appearing at the latest time-points (Figure 2.6B). 
A

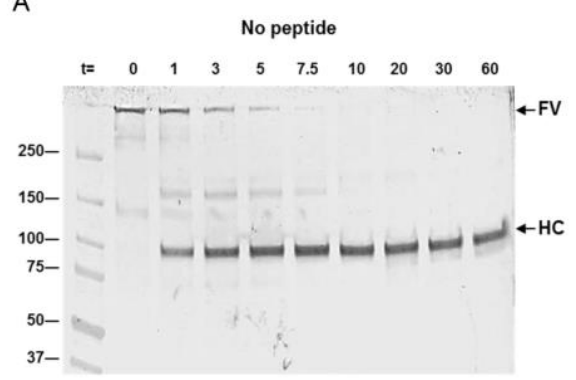

B

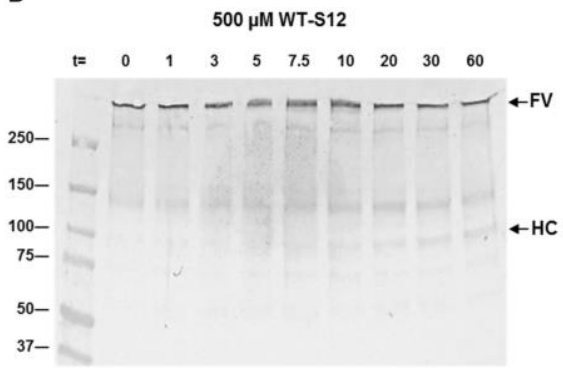

Figure 2.6 Effect of the fibrinogen $\gamma^{\prime}$ peptide on thrombin-mediated FV cleavage. Purified FV was activated with thrombin $(0.5 \mathrm{nM})$ in the absence $(A)$ and presence (B) of fibrinogen $\gamma^{\prime}$ doubly sulfated peptide (WT-S12, $500 \mu \mathrm{M}$ ) and aliquots were drawn at regular time points and analysed by SDS-PAGE and Western blot using a monoclonal antibody directed against the FV heavy chain. FV, single-chain FV; HC, heavy chain.

The effect of the fibrinogen $\gamma^{\prime}$ peptides on thrombin-mediated FV activation was also assessed in (defibrinated) normal plasma, after activation of coagulation with $2 \mathrm{pM}$ TF. The WT-S12 peptide was highly effective in inhibiting FV activation, delaying the formation of $\mathrm{FVa}$ and reducing the maximal concentration of $\mathrm{FVa}$ in a dose-dependent manner (Figure 2.7A). On the other hand, the SCR-S12 peptide had virtually no effect on FVa generation in plasma (Figure 2.7B), confirming that the inhibition of thrombinmediated FV activation by the WT-S12 peptide is a specific effect.

A

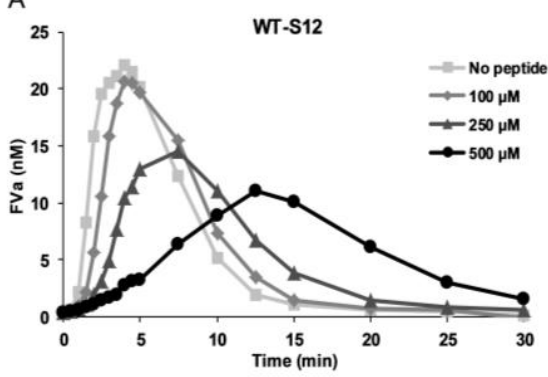

B

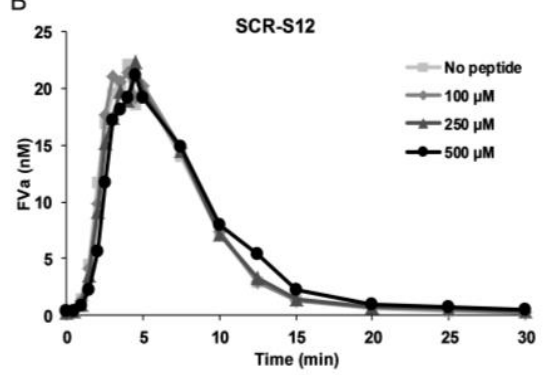

Figure 2.7 Effect of fibrinogen $\gamma^{\prime}$ peptides on FVa generation in plasma. Coagulation was initiated in defibrinated normal plasma with $2 \mathrm{pM}$ TF in the presence of 0-500 $\mu \mathrm{M}$ fibrinogen $\gamma^{\prime}$ doubly sulfated wild-type (WT-S12) (A) or scrambled (SCR-S12) (B) peptide. Subsamples were taken at the indicated time points and FVa cofactor activity was quantified in a prothrombinase-based assay. 


\section{Discussion}

Although it has been known for a long time that fibrin(ogen) has anticoagulant properties [27], the underlying molecular mechanism has never been elucidated in detail. Originally, antithrombin I activity was attributed to the ability of fibrin to adsorb thrombin [6]. Later the fibrinogen $\gamma^{\prime}$ chain was shown to bind thrombin via exosite II and to down-regulate some of its procoagulant functions, particularly FVIII activation [11] and platelet activation [13].

In our study, we have exploited the thrombin generation assay to investigate the overall effects of fibrinogen and fibrinogen $\gamma^{\prime}$ peptide on coagulation. In contrast to conventional clotting tests, the thrombin generation assay probes all three phases of the coagulation process: the initiation phase is reflected in the lag time, whereas the propagation and termination phases are represented by the thrombin peak height and endogenous thrombin potential (the area under the thrombin generation curve). Although an earlier study also suggested that total fibrinogen and particularly $\gamma \mathrm{A} / \gamma^{\prime}$ fibrinogen decreases thrombin generation when added to fibrinogen-deficient plasma [28], the subsampling method used in those experiments did not afford very high time-resolution and accuracy, especially in plasma containing fibrinogen. The recent development of a continuous fluorogenic method for the measurement of thrombin generation in clotting plasma [24] offered us the opportunity to repeat and extend those pioneering experiments.

A comparison between whole and defibrinated plasma showed that total fibrinogen prolongs the lag time of thrombin generation, providing a clear demonstration of the anticoagulant effect of fibrin(ogen). This effect was most pronounced when coagulation was triggered with a low TF concentration and gradually disappeared at higher TF concentrations. This indicates that antithrombin I is only effective at low procoagulant stimuli, which can be explained by the different pathways that underlie thrombin generation at different TF concentrations [25]. In fact, at low TF concentration both the extrinsic and the intrinsic pathways of coagulation contribute to thrombin generation, whereas at higher TF concentration thrombin generation proceeds entirely via the TF pathway.

To study how thrombin exosite II engagement by the fibrinogen $\gamma^{\prime}$ chain affects thrombin generation, we used peptides with the same amino acid sequence as the fibrinogen $\gamma^{\prime}$ C-terminal end (408-427) and various modifications of $Y^{418}$ and $Y^{422}$. With 
the exception of WT-S2, all peptides prolonged the lag time and decreased the peak height of thrombin generation, confirming the overall anticoagulant effect of the fibrinogen $\gamma^{\prime}$ chain. Notably, tyrosine sulfation considerably increased the potency of the peptide, in line with the notion that the two tyrosine residues of the $\gamma^{\prime}$ chain are sulfated in vivo $[3,29]$ and play a critical role in the interaction with thrombin exosite II $[10,30]$. Interestingly, in our assay the doubly sulfated peptide was a more potent anticoagulant than the doubly phosphorylated peptide, which has been used in previous studies $[8,11,30,31]$. The reason for this difference is presently unclear.

The WT-S12 peptide prolonged the lag time and decreased the peak height of thrombin generation in a dose-dependent manner. Similar to the anticoagulant effect of fibrinogen, the anticoagulant effect of the WT-S12 peptide was observed only when coagulation was initiated with low TF concentrations (e.g. 2 pM) and was lost at higher TF concentrations (e.g. 10 pM). Since the SCR-S12 peptide, which contains the same set of negatively charged amino acids and sulfated tyrosines as the WT-S12 peptide, did not affect thrombin generation at any TF concentration, the observed anticoagulant effects of the fibrinogen $\gamma^{\prime}$ peptide are sequence-specific and not attributable to aspecific charge or $\mathrm{pH}$ effects of these highly anionic peptides. Moreover, control experiments indicated that the anticoagulant action of the WT-S12 peptide cannot be ascribed to sequestration of $\mathrm{Ca}^{2+}$-ions (data not shown).

Although the $K_{d}$ for the interaction of the (doubly phosphorylated) fibrinogen $\gamma^{\prime}$ peptide with thrombin exosite II has been estimated to be $<1 \mu \mathrm{M}[8,30]$, in our and other studies [11,32] much higher peptide concentrations were needed to show appreciable effects of the peptide on coagulation in plasma. Presently, we have no explanation for this discrepancy.

The effects of the fibrinogen $\gamma^{\prime}$ peptide on thrombin generation are likely due to the inhibition of thrombin functions that are important for the initiation and propagation of thrombin formation, such as the activation of FV, FVIII and FXI. Although the fibrinogen $\gamma^{\prime}$ peptide has previously been shown to inhibit FVIII activation [11], its anticoagulant effects were not abolished by the presence of an anti-FVIII antibody, a condition where neither FVIII(a) nor FXI(a) contributes to thrombin generation. This suggested that the fibrinogen $\gamma^{\prime}$ peptide may also inhibit thrombin-mediated FV activation, which was subsequently confirmed by specific FV activation experiments in model systems and in plasma. This finding is in line with published data showing that thrombin exosite II is necessary for thrombin-mediated cleavage of FV at $\operatorname{Arg}^{1545}$ [15], 
which in turn is required for full FV activation. Therefore, binding of the fibrinogen $\gamma^{\prime}$ peptide to thrombin exosite II inhibits the activation of both FV and FVIII. Both effects are likely to contribute to the anticoagulant action of the fibrinogen $\gamma^{\prime}$ chain, but their relative importance in physiological situations remains to be elucidated.

In conclusion, we have shown that fibrinogen and the (doubly sulfated) fibrinogen $\gamma^{\prime}$ peptide inhibit thrombin generation at low procoagulant stimuli. When interpreting these results, it is important to bear in mind that the thrombin generation assay as performed in our study probes exclusively coagulation and is not sensitive to platelets, fibrin polymerization or fibrinolysis. In addition, we should be aware that the fibrinogen $\gamma^{\prime}$ peptide mimics only the effects of the fibrinogen $\gamma^{\prime}$ chain that derive from binding to thrombin exosite II and not any other effects that fibrinogen $\gamma \mathrm{A} / \gamma^{\prime}$ may produce by engaging exosite I or the active site of thrombin. Finally, our finding that the fibrinogen $\gamma^{\prime}$ peptide inhibits FV activation by thrombin suggests a novel mechanism underlying the anticoagulant effect of $\gamma \mathrm{A} / \gamma^{\prime}$ fibrinogen, which may contribute to the increased risk of venous thrombosis associated with reduced $\gamma \mathrm{A} / \gamma^{\prime}$ fibrinogen levels such as predicted by the FGG $\mathrm{H} 2$ haplotype. It is tempting to speculate that a possible intervention with (protease-resistant) $\gamma^{\prime}$ peptide mimetic would down-regulate the coagulation potential of plasma in vivo and reduce venous thrombosis risk.

\section{Acknowledgements}

This work was supported by grant nr. 2011-2 from the Dutch Thrombosis Foundation. 


\section{References}

1. Mosesson MW. Fibrinogen and fibrin structure and functions. J Thromb Haemost 2005; 3(8): p. 1894-904.

2. Chung DW and Davie EW. gamma and gamma' chains of human fibrinogen are produced by alternative mRNA processing. Biochemistry 1984; 23(18): p. 4232-6.

3. Wolfenstein-Todel $C$ and Mosesson MW. Carboxy-terminal amino acid sequence of a human fibrinogen gamma-chain variant (gamma'). Biochemistry 1981; 20(21): p. 6146-9.

4. Mosesson MW. Fibrinogen gamma chain functions. J Thromb Haemost 2003; 1(2): p. 2318.

5. Weisel JW. Fibrinogen and fibrin. Adv Protein Chem 2005; 70: p. 247-99.

6. Seegers $W H$, Nieft $M$ and Loomis EC. Note on the Adsorption of Thrombin on Fibrin. Science 1945; 101(2629): p. 520-1.

7. Lane DA, Philippou H and Huntington JA. Directing thrombin. Blood 2005; 106(8): p. 260512.

8. Lovely RS, Moaddel M and Farrell DH. Fibrinogen gamma' chain binds thrombin exosite II. J Thromb Haemost 2003; 1(1): p. 124-31.

9. Meh DA, Siebenlist KR and Mosesson MW. Identification and characterization of the thrombin binding sites on fibrin. J Biol Chem 1996; 271(38): p. 23121-5.

10. Meh DA, Siebenlist KR, Brennan SO, Holyst T and Mosesson MW. The amino acid sequence in fibrin responsible for high affinity thrombin binding. Thromb Haemost 2001; 85(3): p. 470-4.

11. Lovely RS, Boshkov LK, Marzec UM, Hanson SR and Farrell DH. Fibrinogen gamma' chain carboxy terminal peptide selectively inhibits the intrinsic coagulation pathway. $\mathrm{Br} J$ Haematol 2007; 139(3): p. 494-503.

12. Lovely RS, Rein CM, White TC, Jouihan SA, Boshkov LK, Bakke AC, McCarty OJ and Farrell $\mathrm{DH}$. gammaA/gamma' fibrinogen inhibits thrombin-induced platelet aggregation. Thromb Haemost 2008; 100(5): p. 837-46.

13. Lancellotti S, Rutella S, De Filippis V, Pozzi N, Rocca B and De Cristofaro R. Fibrinogenelongated gamma chain inhibits thrombin-induced platelet response, hindering the interaction with different receptors. J Biol Chem 2008; 283(44): p. 30193-204.

14. Kane WH and Davie EW. Blood coagulation factors V and VIII: structural and functional similarities and their relationship to hemorrhagic and thrombotic disorders. Blood 1988; 71(3): p. 539-55.

15. Segers K, Dahlback B, Bock PE, Tans G, Rosing J and Nicolaes GA. The role of thrombin exosites I and II in the activation of human coagulation factor V. J Biol Chem 2007; 282(47): p. 33915-24.

16. Lak M, Keihani M, Elahi F, Peyvandi F and Mannucci PM. Bleeding and thrombosis in 55 patients with inherited afibrinogenaemia. Br J Haematol 1999; 107(1): p. 204-6.

17. Dupuy E, Soria C, Molho P, Zini JM, Rosenstingl S, Laurian C, Bruneval P and Tobelem G. Embolized ischemic lesions of toes in an afibrinogenemic patient: possible relevance to in vivo circulating thrombin. Thromb Res 2001; 102(3): p. 211-9. 
18. Uitte de Willige $\mathrm{S}$, de Visser MC, Houwing-Duistermaat JJ, Rosendaal FR, Vos HL and Bertina RM. Genetic variation in the fibrinogen gamma gene increases the risk for deep venous thrombosis by reducing plasma fibrinogen gamma' levels. Blood 2005; 106(13): p. 4176-83.

19. Grunbacher G, Weger W, Marx-Neuhold E, Pilger E, Koppel H, Wascher T, Marz W and Renner W. The fibrinogen gamma (FGG) $10034 \mathrm{C}>\mathrm{T}$ polymorphism is associated with venous thrombosis. Thromb Res 2007; 121(1): p. 33-6.

20. Nowak-Gottl U, Weiler H, Hernandez I, Thedieck S, Seehafer T, Schulte T and Stoll M. Fibrinogen alpha and gamma genes and factor VLeiden in children with thromboembolism: results from 2 family-based association studies. Blood 2009; 114(9): p. 1947-53.

21. Mosesson MW, Cooley BC, Hernandez I, Diorio JP and Weiler H. Thrombosis risk modification in transgenic mice containing the human fibrinogen thrombin-binding gamma' chain sequence. J Thromb Haemost 2009; 7(1): p. 102-10.

22. Kumar R, Beguin $S$ and Hemker HC. The influence of fibrinogen and fibrin on thrombin generation--evidence for feedback activation of the clotting system by clot bound thrombin. Thromb Haemost 1994; 72(5): p. 713-21.

23. Fredenburgh JC, Stafford AR, Leslie BA and Weitz JI. Bivalent binding to gammaA/gamma'fibrin engages both exosites of thrombin and protects it from inhibition by the antithrombin-heparin complex. J Biol Chem 2008; 283(5): p. 2470-7.

24. Hemker HC, Giesen P, AlDieri R, Regnault V, de Smed E, Wagenvoord R, Lecompte T and Beguin S. The calibrated automated thrombogram (CAT): a universal routine test for hyper- and hypocoagulability. Pathophysiol Haemost Thromb 2002; 32(5-6): p. 249-53.

25. Castoldi E and Rosing J. Thrombin generation tests. Thromb Res 2011; 127 Suppl 3: p. S215.

26. Hoekema L, Castoldi E, Tans G, Girelli D, Gemmati D, Bernardi F and Rosing J. Functional properties of factor $\mathrm{V}$ and factor $\mathrm{Va}$ encoded by the R2-gene. Thromb Haemost 2001; 85(1): p. 75-81.

27. Mosesson MW. Antithrombin I. Inhibition of thrombin generation in plasma by fibrin formation. Thromb Haemost 2003; 89(1): p. 9-12.

28. de Bosch NB, Mosesson MW, Ruiz-Saez A, Echenagucia M and Rodriguez-Lemoin A. Inhibition of thrombin generation in plasma by fibrin formation (Antithrombin I). Thromb Haemost 2002; 88(2): p. 253-8.

29. Farrell DH, Mulvihill ER, Huang SM, Chung DW and Davie EW. Recombinant human fibrinogen and sulfation of the gamma' chain. Biochemistry 1991; 30(39): p. 9414-20.

30. Alexander KS, Fried MG and Farrell DH. Role of Electrostatic Interactions in Binding of Thrombin to the Fibrinogen $\gamma^{\prime}$ Chain. Biochemistry 2012; 51: p. 3445-50.

31. Petrera NS, Stafford AR, Leslie BA, Kretz CA, Fredenburgh JC and Weitz JI. Long range communication between exosites 1 and 2 modulates thrombin function. $J$ Biol Chem 2009; 284(38): p. 25620-9. 
32. Pospisil CH, Stafford AR, Fredenburgh JC and Weitz Jl. Evidence that both exosites on thrombin participate in its high affinity interaction with fibrin. J Biol Chem 2003; 278(24): p. 21584-91. 


\section{Chapter 3}

Fibrinogen $\gamma^{\prime}$ increases the sensitivity to activated protein C in normal and factor V Leiden plasma

Farida Omarova, Shirley Uitte de Willige, Paolo Simioni, Robert A. S. Ariëns, Rogier M. Bertina, Jan Rosing, Elisabetta Castoldi 


\begin{abstract}
Activated protein C (APC) resistance, often associated with the factor $\mathrm{V}$ (FV) Leiden mutation, is the most common risk factor for venous thrombosis. We observed increased APC resistance in carriers of fibrinogen $\gamma$ gene $(F G G)$ haplotype 2 , which is associated with reduced levels of the alternatively spliced fibrinogen $\gamma^{\prime}$ chain. This finding prompted us to study the effect of fibrinogen and its $\gamma^{\prime}$ chain on APC resistance. Fibrinogen, and particularly the $\gamma \mathrm{A} / \gamma^{\prime}$ isoform, improved the response of plasma to added APC in the thrombin generation-based assay. Similarly, a synthetic peptide mimicking the C-terminus of the fibrinogen $\gamma^{\prime}$ chain, which binds thrombin and inhibits its activities, greatly increased the APC sensitivity of normal and FV Leiden plasma, likely due to its ability to inhibit thrombin-mediated activation of FV and FVIII. Although the fibrinogen $\gamma^{\prime}$ peptide also inhibited protein $C$ activation by the thrombin/thrombomodulin complex, it still increased the sensitivity of plasma to endogenously formed APC when thrombin generation was measured in the presence of soluble thrombomodulin. We conclude that fibrinogen, and particularly fibrinogen $\gamma^{\prime}$, increases plasma APC sensitivity. The fibrinogen $\gamma^{\prime}$ peptide might form the basis for pharmacological interventions to counteract APC resistance.
\end{abstract}




\section{Introduction}

The protein C pathway [1,2] is a pivotal anticoagulant mechanism which is initiated by thrombin bound to the membrane protein thrombomodulin (TM). The thrombin/TM complex converts the zymogen protein $C$ into the serine-protease activated protein $C$ (APC), which inactivates coagulation factors Va (FVa) and VIIla (FVIIla) by limited proteolysis. The in vitro addition of APC to plasma produces an anticoagulant response, which can be quantified in an APTT-based assay (as a prolongation of the clotting time) or in a thrombin generation-based assay (as a decrease of the area under the thrombin generation curve) [3]. A poor response of plasma to the anticoagulant action of APC, known as APC resistance [4], is the most prevalent risk factor for venous thrombosis in the Caucasian population. APC resistance is usually associated with carriership of the $\mathrm{FV} \mathrm{Arg}^{506} \rightarrow \mathrm{Gln}$ (FV Leiden) mutation [5], which abolishes one of the APC-cleavage sites on FVa. However, altered levels of several proand anticoagulant factors, such as prothrombin, FV, FVIII, factor $\mathrm{X}$, protein $\mathrm{S}$ and tissue factor pathway inhibitor, also cause plasma APC resistance $[6,7]$.

Fibrinogen is a large glycoprotein that is produced in the liver and circulates in plasma at a concentration of $\sim 3 \mathrm{mg} / \mathrm{mL}$. Structurally, it comprises three polypeptide chains $(A \alpha, B \beta$ and $\gamma$ ), each of which is present in two copies in the fibrinogen molecule. The human $\gamma$ chain, encoded by the FGG gene, occurs in two structurally and functionally different isoforms that are generated by alternative splicing and polyadenylation of the FGG pre-mRNA [8]. The more abundant $\gamma \mathrm{A}$ isoform has a short C-terminal tail of four amino acids ( $\gamma$ A408-411, AGDV) containing a platelet-binding site, whereas the less abundant $\gamma^{\prime}$ isoform has an extended C-terminal tail of 20 amino acids ( $\gamma^{\prime} 408$ 427, VPREHPAETEYDSLYPEDDL) containing a high-affinity binding site for thrombin exosite II [9-11]. Random pairing of the $\gamma$ chain isoforms generates three types of fibrinogen molecules: $\gamma \mathrm{A} / \gamma \mathrm{A}(85-92 \%), \gamma \mathrm{A} / \gamma^{\prime}(8-15 \%)$ and $\gamma^{\prime} / \gamma^{\prime}(<0.5 \%)$.

Being the precursor of fibrin and promoting platelet aggregation, fibrinogen plays a major role in haemostasis. However, it has been known for a long time that fibrin(ogen) also binds thrombin and inhibits its activity [12]. While this anticoagulant activity of fibrin(ogen), known as "antithrombin I", is still poorly understood, it has recently been shown that the interaction of the C-terminus of the fibrinogen $\gamma^{\prime}$ chain with thrombin exosite II inhibits thrombin-mediated activation of FVIII [13] and FV [14], as well as platelets $[15,16]$. The physiological relevance of this anticoagulant 
mechanism is underscored by the 2 to 3 -fold increased risk of venous thrombosis associated with the common FGG $\mathrm{H} 2$ haplotype, which is associated with reduced levels of fibrinogen $\gamma^{\prime}$ without affecting total fibrinogen levels [17-21].

Recently, we observed that carriership of the FGG H2 haplotype is associated with higher plasma APC resistance in FV Leiden carriers. This unexpected finding prompted us to investigate the effect of fibrinogen and its $\gamma$ chain isoforms on APC resistance in normal and FV Leiden plasma.

\section{Materials and methods}

\section{Population study}

In the frame of a previous study, approved by the Ethical Committee of Padua Academic Hospital and conducted in accordance with the Declaration of Helsinki, we determined the effects of several haemostasis-related SNPs on thrombin generation initiated by $6.8 \mathrm{pM}$ TF in the absence and presence of $10 \mathrm{nM}$ APC in 188 FV Leiden heterozygotes [22].

In the present study, the same population was genotyped for the FGG 10034 C>T SNP (rs2066865), which tags the FGG H2 haplotype [17]. Genotyping was performed by polymerase chain reaction (PCR)-mediated amplification of a 435-bp genomic DNA fragment followed by restriction analysis with Rsa I (Fermentas, Thermo Fischer Scientific, Landsmeer, Netherlands).

The effect of $F G G \mathrm{H} 2$ on thrombin generation was determined by multiple regression analysis and expressed as unstandardized regression coefficient (B). Besides the FGG $\mathrm{H} 2$ genotype $(0,1$ or 2$)$, the regression model included age, sex, and the levels of prothrombin, factor $\mathrm{X}$, antithrombin, protein $\mathrm{S}$ and tissue factor pathway inhibitor as independent variables.

\section{Plasma samples}

A normal plasma pool was prepared by pooling platelet-free citrated plasma from 34 healthy volunteers (20 males and 14 females, mean age 34.5 years) free of medication. Pooled FV Leiden plasma was prepared from citrated plasma of 16 heterozygous carriers of FV Leiden not using any medication (referred to as FV Leiden heterozygous plasma throughout). In some experiments, these plasmas were 
defibrinated by incubation with $1.17 \mathrm{U} / \mathrm{mL}$ Ancrod (NIBSC, Potters Bar, Hertfordshire, UK) for 10 minutes at $37^{\circ} \mathrm{C}$ and subsequent clot removal with a spatula.

Congenitally fibrinogen-deficient plasma was purchased from George King BioMedical Inc., Overland Park, KS, USA and reconstituted with either Hepes-buffered saline (25 mM Hepes, $175 \mathrm{mM} \mathrm{NaCl}$, pH 7.7 at room temperature) or purified $\gamma \mathrm{A} / \gamma \mathrm{A}$ or $\gamma \mathrm{A} / \gamma^{\prime}$ fibrinogen to a final concentration of $1.4 \mathrm{mg} / \mathrm{mL}$.

\section{Purification of $\gamma \mathrm{A} / \gamma \mathrm{A}$ and $\gamma \mathrm{A} / \gamma^{\prime}$ fibrinogen}

Human fibrinogen was purchased from Enzyme Research Laboratories, Swansea, UK. $\gamma \mathrm{A} / \gamma \mathrm{A}$ (peak 1) and $\gamma \mathrm{A} / \gamma^{\prime}$ (peak 2) fibrinogen were separated by ion-exchange chromatography, as described [23,24]. To eliminate factor XIII, both peaks were subjected to a two-step ammonium sulfate precipitation protocol [25]. In step 1, the fibrinogen peaks were supplemented with $\mathrm{CaCl}_{2}$ to a final concentration of $7.9 \mathrm{mM}$ and an ammonium sulfate solution was added up to $20 \%$ saturation under stirring at $4^{\circ} \mathrm{C}$. After 90 minutes the solution was centrifuged at $3000 \mathrm{~g}$ for 20 minutes. In step 2 , the ammonium sulfate concentration in the supernatant of step 1 was increased to $33 \%$ saturation and after 90 minutes the solution was again centrifuged at $3000 \mathrm{~g}$ for 20 minutes. The pellets, which contained $\gamma \mathrm{A} / \gamma \mathrm{A}$ or $\gamma \mathrm{A} / \gamma^{\prime}$ fibrinogen, were dialysed against Hepes-buffered saline. Purity was examined by $8 \%$ sodium dodecyl sulfatepolyacrylamide gel electrophoresis (SDS-PAGE), and concentration was determined by absorbance at $280 \mathrm{~nm}$ using an extinction coefficient $(\varepsilon)$ of $1.51 \mathrm{mg}^{-1} \mathrm{~mL} \mathrm{~cm}^{-1}$.

\section{Fibrinogen $\gamma^{\prime}$ peptides}

Synthetic wild-type fibrinogen $\gamma^{\prime}$ C-terminal peptide (WT-S12, AcVPREHPAETEY(SO $\left.\mathrm{SO}_{3}\right) \mathrm{DSLY}\left(\mathrm{SO}_{3}\right)$ PEDDL-OH) and scrambled control peptide (SCR-S12, Ac$\operatorname{DESELDAY}\left(\mathrm{SO}_{3}\right) \operatorname{TPLPRPVEDHY}\left(\mathrm{SO}_{3}\right) \mathrm{E}-\mathrm{OH}$ ) were obtained from Pepscan (Lelystad, the Netherlands). Both peptides were sulfated on both tyrosine residues. Synthesis and purification details have been previously reported [14]. Lyophilized peptides were resuspended in Hepes-buffered saline and stored in aliquots at $-80^{\circ} \mathrm{C}$.

\section{Thrombin generation-based APC resistance assay}

Thrombin generation was measured using Calibrated Automated Thrombography (CAT) [26], essentially as described [14]. Briefly, plasma was mixed with corn trypsin 
inhibitor (Hematologic Technologies, Essex Junction, VT, USA) to prevent contact activation, and incubated with tissue factor (TF) (Dade Innovin, Marburg, Germany) and synthetic phospholipid vesicles (1,2-dioleoyl-sn-glycero-3-phosphoserine (DOPS)/1,2-dioleoyl-sn-glycero-3-phosphocholine (DOPC)/1,2-dioleoyl-sn-glycero-3phosphoethanolamine (DOPE), 20/60/20, mol $/ \mathrm{mol} / \mathrm{mol}$ ) for $10 \mathrm{~min}$ at $37^{\circ} \mathrm{C}$. Subsequently, APC (Kordia, Leiden, Netherlands) or soluble TM (sTM, Asahi Kasei Pharma, Tokyo, Japan) was added and coagulation was immediately initiated with a mixture of $\mathrm{CaCl}_{2}$ and fluorogenic substrate for thrombin (Z-Gly-Gly-Arg-AMC, I-1140, Bachem, Bubendorf, Switzerland). Final concentrations in the wells were $44 \mu \mathrm{g} / \mathrm{mL}$ corn trypsin inhibitor, $10 \mathrm{pM}$ TF (for experiments with APC) or $4 \mathrm{pM}$ TF (for experiments with sTM), $30 \mu \mathrm{M}$ phospholipids, 0-10 nM APC or 0-20 nM sTM, $12 \mathrm{mM}$ added $\mathrm{CaCl}_{2}$ and $300 \mu \mathrm{M}$ thrombin substrate. All thrombin generation curves were measured in duplicate. Fluorescence was read in a Fluoroskan Ascent reader (Thermo Labsystems, Helsinki, Finland) and thrombin generation parameters were calculated using the Thrombinoscope software (Thrombinoscope, Maastricht, The Netherlands). APC resistance was expressed as the ratio of the endogenous thrombin potentials (ETPs) obtained in the presence and absence of APC or STM (residual ETP). The higher the residual ETP, the higher the APC resistance.

\section{APTT-based APC resistance assay}

The APTT-based APC resistance of normal and FV Leiden heterozygous plasma was measured using the Coatest APC resistance kit (Chromogenix, Milan, Italy) according to the manufacturer's instructions. Clotting times were measured in triplicate. The APC sensitivity ratio (APCsr) was defined as the ratio of the clotting times determined in the presence and absence of APC. The lower the APCsr, the higher the APC resistance.

\section{Protein $\mathrm{C}$ activation assay}

Purified human protein C (Hyphen BioMed, Neuville-sur-Oise, France, $500 \mathrm{nM}$ ) was activated at $37^{\circ} \mathrm{C}$ with $5 \mathrm{nM}$ human thrombin (Hematologic Technologies) and $10 \mathrm{nM}$ human sTM in $25 \mathrm{mM}$ Hepes, $140 \mathrm{mM} \mathrm{NaCl}, 3 \mathrm{mM} \mathrm{CaCl}$, $\mathrm{pH} 7.7$ at RT, and $5 \mathrm{mg} / \mathrm{ml}$ bovine serum albumin (BSA) in the presence of increasing concentrations (0-500 $\mu \mathrm{M})$ of fibrinogen $\gamma^{\prime}$ WT-S12 or SCR-S12 peptide. At 0, 30 and 60 minutes of activation 
subsamples were drawn from these mixtures into an EDTA-buffer (50 mM Tris, $175 \mathrm{mM} \mathrm{NaCl}, 20 \mathrm{mM}$ EDTA, pH 7.9 at RT, $0.5 \mathrm{mg} / \mathrm{ml}$ ovalbumin, and $5 \mathrm{nM}$ hirudin to prevent further activation of protein C). APC activity was determined spectrophotometrically with chromogenic substrate Biophen CS-21(66) (Hyphen BioMed). The assay was calibrated using known amounts of APC. Rates of protein C activation were plotted as a function of peptide concentration and fitted to the equation of a rectangular hyperbola, from which half-maximal inhibitory concentrations $\left(\mathrm{IC}_{50}\right)$ were calculated.

\section{Results}

\section{Effect of FGG $\mathrm{H} 2$ haplotype on APC resistance in FV Leiden carriers}

In the frame of a study aimed at determining the effect of common genetic variation on thrombin generation [22], we genotyped 188 FV Leiden heterozygotes for several SNPs in haemostasis-related genes. In the present study this population was genotyped for FGG 10034 C>T (rs2066865), which tags the FGG H2 haplotype. Figure 3.1 shows the effects of the $\mathrm{H} 2$ haplotype on the ETP. The ETP-APC was $634.4 \pm 129.8 \mathrm{nM} \cdot \mathrm{min}$ in non-carriers $(\mathrm{N}=99), 673.5 \pm 143.8 \mathrm{nM} \cdot \mathrm{min}$ in heterozygous carriers $(\mathrm{N}=78)$ and $641.5 \pm 139.0 \mathrm{nM}$.min in homozygous carriers $(\mathrm{N}=11)$ of the minor allele (Figure 3.1A), indicating that the FGG H2 genotype does not affect the ETP-APC ( $B=11.0 \mathrm{nM} \cdot \mathrm{min} /$ haplotype copy, $p=0.312$ ). In contrast, the $\mathrm{ETP}_{+\mathrm{APC}}$ was $230.5 \pm 149.0$ nM.min in non-carriers, $337.6 \pm 176.5 \mathrm{nM} . \mathrm{min}$ in heterozygous carriers and $396.6 \pm 113.1 \mathrm{nM} . \mathrm{min}$ in homozygous carriers of the minor allele (Figure 3.1B), indicating that the $F G G \mathrm{H} 2$ haplotype considerably increases the ETP $+A P C$ $(B=62.4 \mathrm{nM} . \mathrm{min} / \mathrm{haplotype}$ copy, $\mathrm{p}<0.001)$. This unexpected finding suggested a possible relationship between fibrinogen $\gamma^{\prime}$ level and plasma APC resistance and prompted us to study the effect of fibrinogen and its $\gamma$ chain isoforms on the response of normal and FV Leiden plasma to APC. 

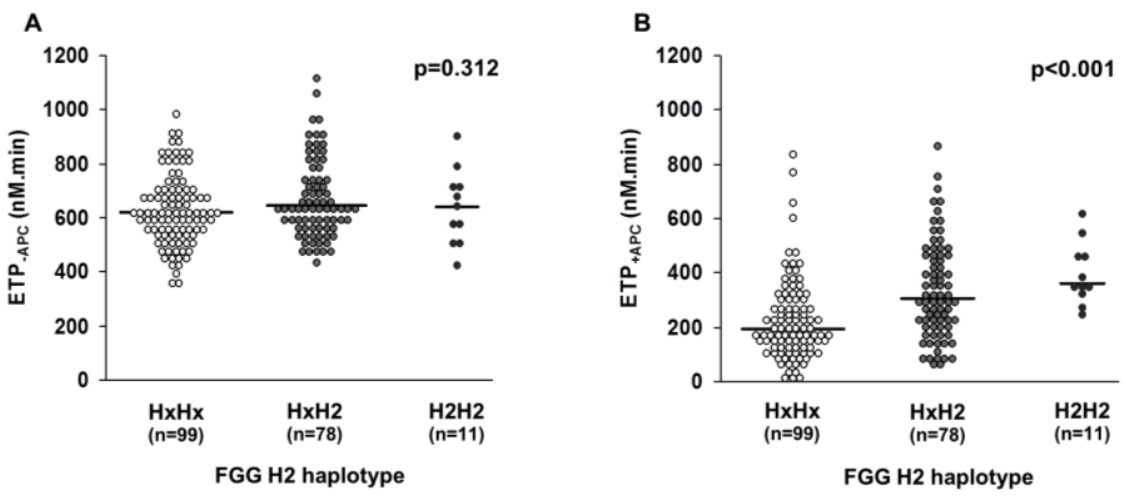

Figure 3.1 Effect of the FGG $\mathrm{H} 2$ genotype on plasma APC resistance. FGG $\mathrm{H} 2$ genotype and thrombin generation at $6.8 \mathrm{pM}$ TF in the absence and presence of $10 \mathrm{nM}$ APC were determined in $188 \mathrm{FV}$ Leiden heterozygotes. The $\operatorname{ETP}_{-A P C}(A)$ and the $\operatorname{ETP}_{+A P C}(B)$ were plotted as a function of the FGG $\mathrm{H} 2$ genotype. $\mathrm{Hx}$ indicates any other $F G G$ haplotype except $\mathrm{H} 2$. The $\mathrm{p}$-values refer to the regression coefficients of the ETP -APC $_{\text {. }}$ and $\mathrm{ETP}_{+\mathrm{APC}}$ Vs. FGG $\mathrm{H} 2$ genotype.

\section{Effect of total fibrinogen and the purified $\gamma$ chain fibrinogen isoforms on the APC response}

To study the effect of total fibrinogen on the plasma APC response, we compared thrombin generation in whole and defibrinated normal and FV Leiden heterozygous plasma in the absence and presence of increasing concentrations of APC. In the absence of APC, thrombin generation was higher in whole plasma than in defibrinated plasma (ETP 678.2 nM.min and 479.6 nM.min for whole and defibrinated normal plasma; $661.9 \mathrm{nM} . \mathrm{min}$ and $503.2 \mathrm{nM}$.min for whole and defibrinated FV Leiden heterozygous plasma) (Figure 3.2). This is in line with published data and is probably due to the ability of fibrinogen to protect thrombin from inhibition by antithrombin and $\alpha_{2}$-macroglobulin [27-30]. However, the addition of APC decreased thrombin generation relatively more in whole plasma, resulting in lower ETPs in whole plasma than in defibrinated plasma at each APC concentration (Figure 3.2). At the highest APC concentration the ETP was almost 10 times (normal plasma) and $>3$ times (FV Leiden heterozygous plasma) lower in whole than in defibrinated plasma. Consequently, in both plasmas the residual ETP at each APC concentration was also lower in whole plasma than in defibrinated plasma (Figure 3.2C,F), suggesting that total fibrinogen makes plasma more sensitive to the anticoagulant action of APC. Whole plasma from 
a FV Leiden homozygous carrier was also more sensitive to APC than defibrinated plasma of the same individual (data not shown).
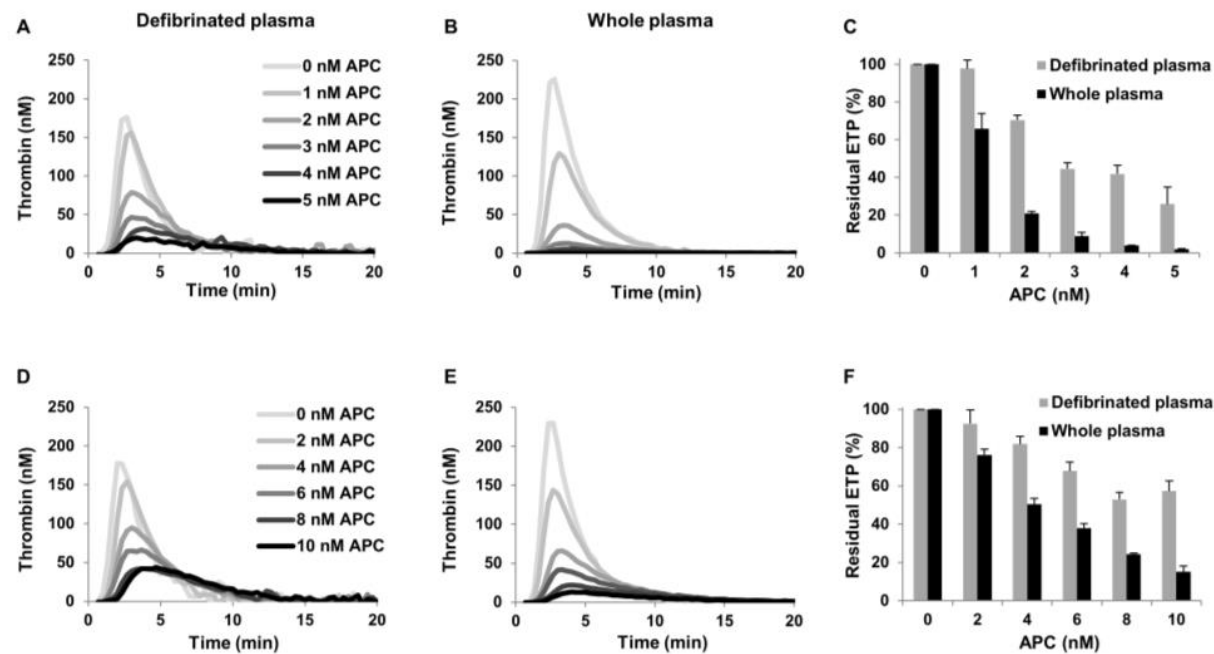

Figure 3.2 Effect of total fibrinogen on the ETP-based APC response in pooled normal plasma and in FV Leiden heterozygous plasma. Thrombin generation was initiated with 10 PM TF in the presence of 0-5 nM APC in defibrinated and whole normal plasma (A, $B$ ) and in the presence of 0-10 $\mathrm{nM}$ APC in defibrinated and whole FV Leiden heterozygous plasma (D, E). Residual ETPs (ETP $\left.{ }_{+A P C} / E_{T P} P_{-A P C}\right)$ of normal (C) and FV Leiden heterozygous (F) plasma were plotted as a function of the APC concentration. Averages of triplicate experiments are shown. Error bars indicate the standard error of the mean.

To check whether the two $\gamma$ chain fibrinogen isoforms differ in their effects on plasma APC response, we reconstituted congenitally fibrinogen-deficient plasma with $1.4 \mathrm{mg} / \mathrm{ml}$ purified $\gamma \mathrm{A} / \gamma \mathrm{A}$ or $\gamma \mathrm{A} / \gamma^{\prime}$ fibrinogen (corresponding to $\sim 50 \%$ of the total fibrinogen concentration in normal plasma) and measured thrombin generation in the absence and presence of increasing concentrations of APC. In line with the results obtained with whole and defibrinated plasma, supplementation of fibrinogendeficient plasma with fibrinogen resulted in higher thrombin generation in the absence of APC, but also increased the sensitivity of plasma to the anticoagulant action of APC (Figure 3.3). Both effects were more pronounced when fibrinogen- 
deficient plasma was reconstituted with $\gamma \mathrm{A} / \gamma^{\prime}$ fibrinogen compared to reconstitution with $\gamma \mathrm{A} / \gamma \mathrm{A}$ fibrinogen. The ETPs obtained in the absence of APC and at the highest APC concentration (10 nM) were 627 nM.min and 217 nM.min (residual ETP 34.6\%) in fibrinogen-deficient plasma, 852 nM.min and 109 nM.min (residual ETP 12.8\%) in plasma reconstituted with $\gamma \mathrm{A} / \gamma \mathrm{A}$ fibrinogen, and $1310 \mathrm{nM} . \mathrm{min}$ and $92 \mathrm{nM} . \mathrm{min}$ (residual ETP 7.0\%) in plasma reconstituted with $\gamma A / \gamma^{\prime}$ fibrinogen. These results indicate that, although both fibrinogen isoforms increase the sensitivity of plasma for APC, the $\gamma \mathrm{A} / \gamma^{\prime}$ isoform has a more pronounced effect.
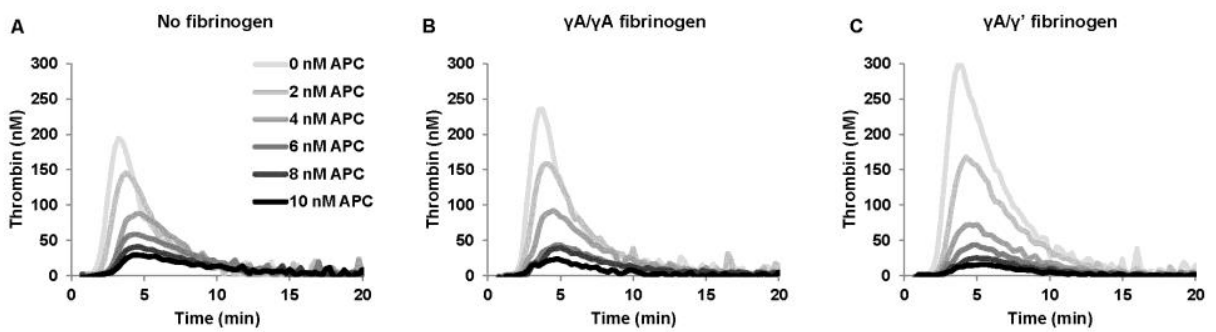

D

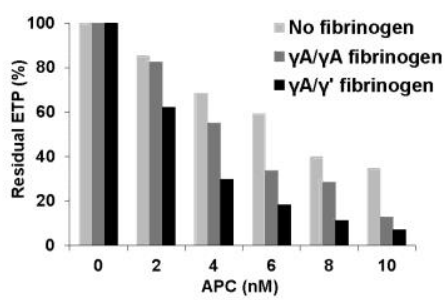

Figure 3.3 Effect of $\gamma \mathrm{A} / \gamma \mathrm{A}$ and $\gamma \mathrm{A} / \gamma^{\prime}$ fibrinogen on the ETP-based APC response in reconstituted fibrinogen-deficient plasma. Thrombin generation was initiated with $10 \mathrm{pM}$ TF in the presence of 0-10 nM APC in fibrinogen-deficient plasma supplemented with buffer $(A)$ or with $1.4 \mathrm{mg} / \mathrm{ml} \gamma \mathrm{A} / \gamma \mathrm{A}$ fibrinogen $(\mathrm{B})$ or $1.4 \mathrm{mg} / \mathrm{ml}$ $\gamma A / \gamma^{\prime}$ fibrinogen $(C)$. Residual ETPs (ETP $+A P C / E_{\text {ETP }}$-APC ) were plotted as a function of the APC concentration (D). Averages of duplicate experiments are shown.

\section{Effects of the fibrinogen $\gamma^{\prime}$ peptides on the APC response of normal and FV Leiden heterozygous plasma}

To investigate whether the effect of $\gamma \mathrm{A} / \gamma^{\prime}$ fibrinogen on the APC response of plasma is mediated by thrombin inhibition via occupation of exosite II, we used a synthetic 20 
amino acid peptide homologous to the C-terminus of this chain (WT-S12) and a scrambled control peptide (SCR-S12). Thrombin generation was measured in normal plasma at increasing concentrations of APC in the absence and presence of $250 \mu \mathrm{M}$ peptide (Figure 3.4A-C) and residual ETPs were calculated (Figure 3.4D). Addition of the WT-S12 peptide only slightly affected the ETP-APC (which was 783.3 nM.min and $677.3 \mathrm{nM}$.min in the absence and presence of peptide, respectively), as previously observed at this TF concentration [14], but markedly decreased the ETP + APC and the residual ETP. At $3 \mathrm{nM} \mathrm{APC}$, the ETP in the presence of the WT-S12 peptide was 19.7 nM.min vs. $94.7 \mathrm{nM} . \mathrm{min}$ in the absence of peptide. Accordingly, the residual ETP in the presence of WT-S12 peptide was $>75 \%$ lower than in its absence. In contrast, addition of the SCR-S12 did not appreciably influence the ETP in the absence or presence of APC or the residual ETP.
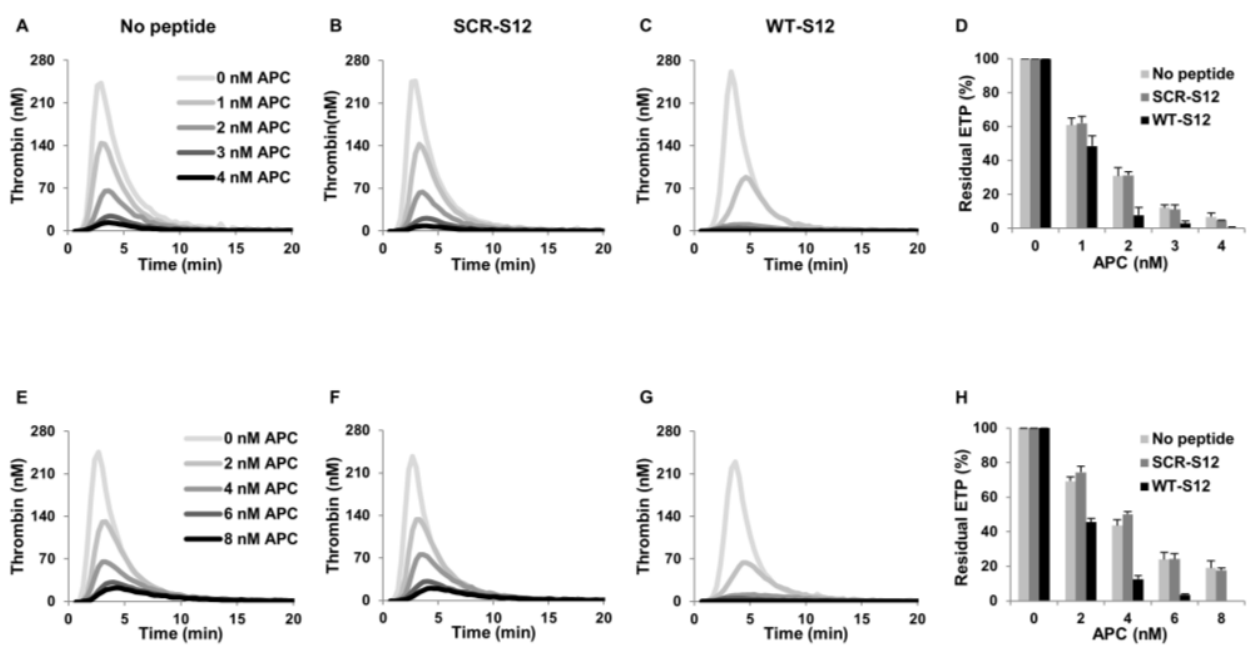

Figure 3.4 Effect of fibrinogen $\gamma^{\prime}$ peptides on the ETP-based APC response in normal and FV Leiden heterozygous plasma. Thrombin generation was initiated with $10 \mathrm{pM}$ TF in the presence of 0-4 $\mathrm{nM} \mathrm{APC} \mathrm{(normal} \mathrm{plasma,} \mathrm{A-C)} \mathrm{or} \mathrm{0-8} \mathrm{nM} \mathrm{APC} \mathrm{(FV} \mathrm{Leiden}$ heterozygous plasma, $\mathrm{E}-\mathrm{G}$ ) in the absence $(\mathrm{A}, \mathrm{E})$ and presence of $250 \mu \mathrm{M}$ SCR-S12 peptide $(B, F)$ or WT-S12 peptide $(C, G)$. Residual ETPs (ETP ${ }_{+A P C} /$ ETP-APC $\left._{-}\right)$of normal (D) and FV Leiden $(\mathrm{H})$ plasma were plotted as a function of the APC concentration. Averages of triplicate experiments are shown. Error bars indicate the standard error of the mean. 
Similar experiments were performed in the FV Leiden heterozygous plasma (Figure 3.4E-H). Like in normal plasma, the WT-S12 and SCR-S12 peptides hardly affected thrombin generation in the absence of APC, while the WT-S12 peptide (but not the SCR-S12 peptide) considerably reduced thrombin generation in the presence of APC. At $6 \mathrm{nM}$ APC, the WT-S12 peptide decreased the ETP from $170.3 \mathrm{nM}$.min to 22.7 nM.min, whereas the SCR-S12 peptide had virtually no effect (163.3 nM.min). This was reflected in the residual ETP, which was $>80 \%$ lower in the presence of WT-S12 compared to the residual ETP in its absence. Similar effects of WT-S12 and SCR-S12 peptides were observed in plasma from a FV Leiden homozygous carrier (data not shown).

The effect of the fibrinogen $\gamma^{\prime}$ peptide on plasma APC resistance was also tested with the commonly used APTT-based assay (Figure 3.5). To this end, clotting times in the absence and presence of APC were measured in plasma supplemented with 0-100 $\mu \mathrm{M}$ WT-S12 or SCR-S12 peptide. In normal plasma, increasing concentrations of the WT-S12 peptide caused a progressive prolongation of the APTT-APC (from $35.0 \mathrm{sec}$ to $56.3 \mathrm{sec}$ ) and even more of the APTT + APC (from $109.9 \mathrm{sec}$ to $398.3 \mathrm{sec}$ ), increasing the APCsr from 3.14 in the absence of peptide to 7.08 in the presence of $100 \mu \mathrm{M}$ peptide (Figure 3.5A). In contrast, the SCR-S12 peptide had only a minor effect on the clotting times and on the APCsr, which increased from 3.22 in the absence of peptide to 3.71 in the presence of $100 \mu \mathrm{M}$ peptide. In FV Leiden heterozygous plasma, the WT-S12

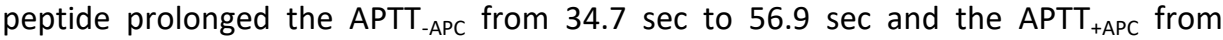
$82.2 \mathrm{sec}$ to $232 \mathrm{sec}$, causing the APCsr to increase from 2.37 in the absence of peptide to 4.07 in the presence of $100 \mu \mathrm{M}$ peptide (Figure 3.5B). Interestingly, the addition of $25 \mu \mathrm{M}$ WT-S12 peptide was already sufficient to normalize the APCsr of FV Leiden heterozygous plasma. In contrast, the SCR-S12 peptide was virtually ineffective, changing the APCsr of FV Leiden heterozygous plasma from 2.37 in the absence of peptide to 2.42 in the presence of $100 \mu \mathrm{M}$ peptide.

Overall, these data show that the fibrinogen $\gamma^{\prime}$ C-terminal peptide improves the anticoagulant response of normal and FV Leiden plasma to APC. 

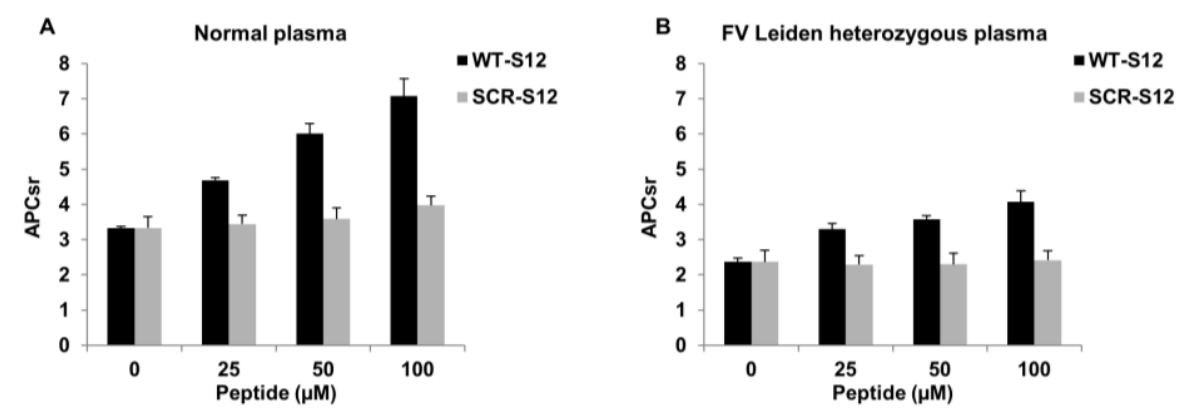

Figure 3.5 Effect of fibrinogen $\gamma^{\prime}$ peptides on the APTT-based APC response in normal and FV Leiden heterozygous plasma. APC resistance was measured with the APTTbased assay in normal (A) and FV Leiden heterozygous (B) plasma supplemented with 0-100 $\mu \mathrm{M}$ WT-S12 or SCR-S12 peptide. APC-sensitivity ratios (APCsr) were plotted as a function of the peptide concentration. All clotting times were measured in triplicate. Error bars indicate the standard error of the mean.

\section{Effect of fibrinogen $\gamma^{\prime}$ peptides on thrombin generation determined in the absence and presence of TM in normal and FV Leiden heterozygous plasma}

In vivo, protein $\mathrm{C}$ is activated by thrombin bound to $\mathrm{TM}$. Since the $\mathrm{C}$-terminus of the fibrinogen $\gamma^{\prime}$ chain targets exosite II of thrombin, it might inhibit protein $\mathrm{C}$ activation by the thrombin/TM complex, thereby abolishing its own anticoagulant effect observed in the presence of pre-formed APC. Hence, we also determined the effects of the fibrinogen $\gamma^{\prime}$ peptides on thrombin generation measured at $4 \mathrm{pM}$ TF in the absence and presence of STM. In the absence of peptides, increasing concentrations of sTM progressively decreased thrombin generation in normal plasma (Figure 3.6A) and, to a lesser extent, in FV Leiden heterozygous plasma (Figure 3.6E). Addition of the WT-S12 peptide (Figure 3.6C,G), but not of the SCR-S12 peptide (Figure 3.6B,F), dramatically decreased thrombin generation at each STM concentration. At the highest sTM concentration, the WT-S12 peptide reduced the ETP ${ }_{+T M}$ from $94.4 \mathrm{nM}$.min to $16.5 \mathrm{nM}$.min in normal plasma and from $132.5 \mathrm{nM}$.min to $25.9 \mathrm{nM}$.min in FV Leiden heterozygous plasma. As a result, the residual ETP was $~ 80 \%$ lower it the presence of WT-S12 than in its absence in both normal and FV Leiden plasma (Figure 3.6D,H). 

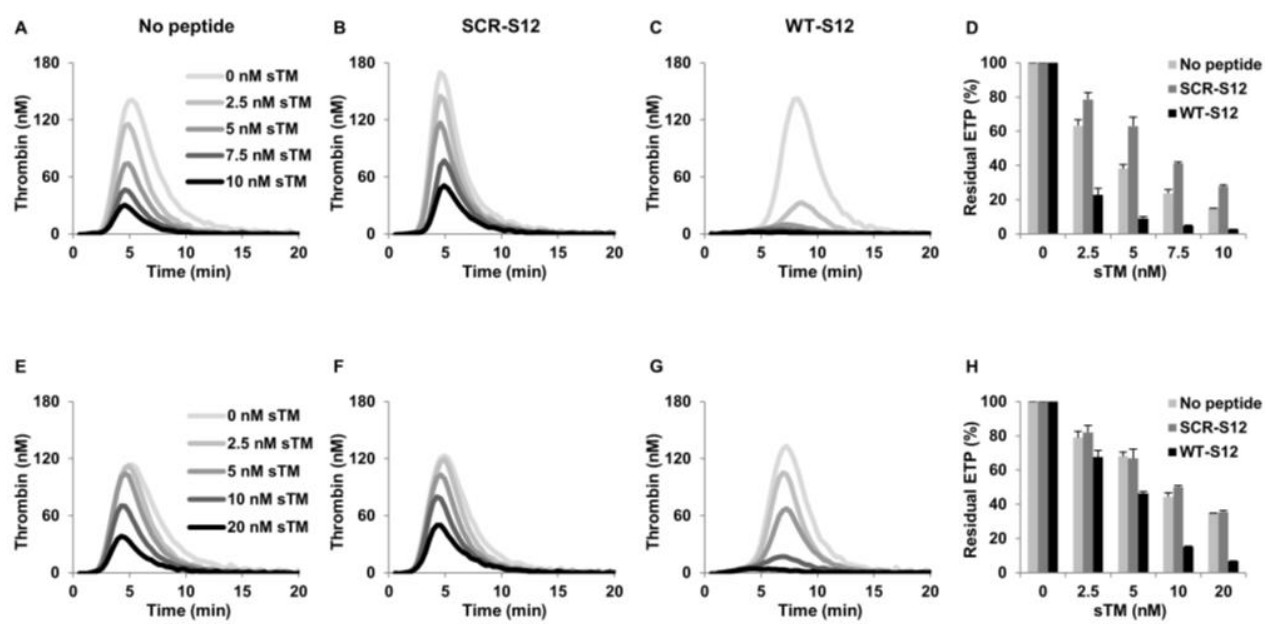

Figure 3.6 Effect of fibrinogen $\gamma^{\prime}$ peptides on the ETP-based sTM response of normal and FV Leiden heterozygous plasma. Thrombin generation was initiated with $4 \mathrm{pM} T F$ in the presence of 0-10 nM sTM in normal plasma (A-C) or 0-20 nM sTM in FV Leiden heterozygous plasma $(E-G)$ in the absence $(A, E)$ or presence of $250 \mu \mathrm{M}$ SCR-S12 peptide $(B, F)$ or WT-S12 peptide $(C, G)$. Residual ETPs (ETP + TM $/$ ETP $_{- \text {TM }}$ ) of normal plasma (D) and FV Leiden heterozygous plasma $(H)$ were plotted as a function of the STM concentration. Averages of triplicate experiments are shown. Error bars indicate the standard error of the mean.

\section{Effect of the fibrinogen $\gamma^{\prime}$ peptides on protein C activation}

Finally, we also investigated the direct effect of the WT-S12 and SCR-S12 peptides on protein $\mathrm{C}$ activation by the thrombin/sTM complex. Both peptides inhibited protein $\mathrm{C}$ activation in a dose-dependent manner, but WT-S12 was clearly more potent than SCR-S12 (Figure 3.7A,B). At the highest peptide concentration $(500 \mu \mathrm{M})$, protein $\mathrm{C}$ activation was inhibited $\sim 90 \%$ by the WT-S12 peptide $v s . \sim 40 \%$ by the SCR-S12 peptide. The $\mathrm{IC}_{50}$ values were $36.5 \mu \mathrm{M}$ for WT-S12 and $582.8 \mu \mathrm{M}$ for SCR-S12 (Figure 3.7C). 
A

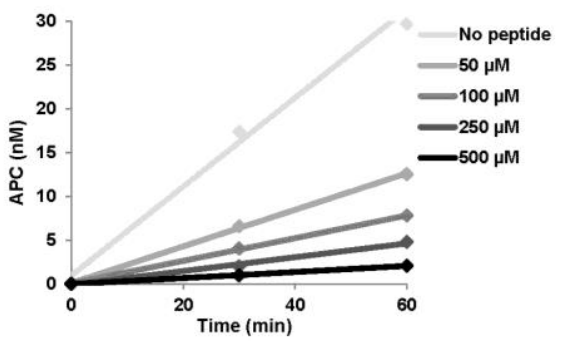

c

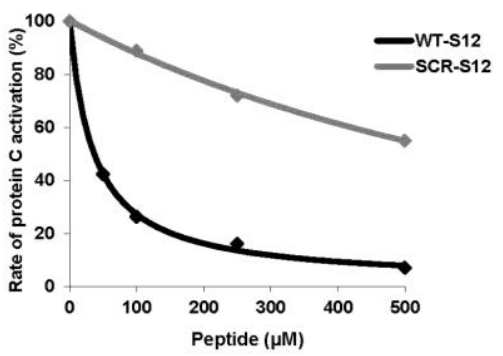

SCR-S12

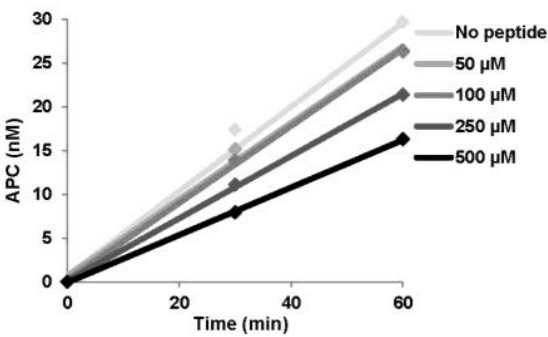

Figure 3.7 Effect of fibrinogen $\gamma^{\prime}$ peptides on protein $C$ activation by the thrombin/sTM complex. Purified protein $\mathrm{C}(500 \mathrm{nM})$ was activated with thrombin ( $5 \mathrm{nM})$ and sTM $(10 \mathrm{nM})$ in the presence of $0-500 \mu \mathrm{M}$ WT-S12 (A) or SCR-S12 (B) peptide. Subsamples were taken from the activation mix after 30 and $60 \mathrm{~min}$ and assayed for APC activity. Rates of protein C activation were plotted as a function of peptide concentration and fitted to the equation of a rectangular hyperbola (C).

\section{Discussion}

Beside its essential pro-haemostatic role, fibrin(ogen) is known to express anticoagulant activity as a thrombin inhibitor. In the present paper we show that fibrinogen, and particularly fibrinogen $\gamma^{\prime}$, increases the sensitivity of plasma to APC in the thrombin generation- and APTT-based assays. This phenomenon was not observed in previous studies that investigated the relationship between plasma factor levels and APC resistance [6,7], possibly because a) the variation in fibrinogen level in healthy individuals is not large enough for the effect to be picked up; and b) the effect is mainly (although not exclusively) due to fibrinogen $\gamma^{\prime}$, which makes up only $8-15 \%$ of total fibrinogen in plasma. In our study design the effect of fibrinogen on APC 
sensitivity was magnified by comparing the complete absence of fibrinogen (defibrinated plasma or congenitally fibrinogen-deficient plasma) with $100 \%$ total fibrinogen (whole plasma) or with $\sim 50 \% \gamma \mathrm{A} / \gamma \mathrm{A}$ or $\gamma \mathrm{A} / \gamma^{\prime}$ fibrinogen (reconstituted fibrinogen-deficient plasma). This was only possible in the ETP-based APC resistance assay, which can also be performed in plasma without fibrinogen. In the APTT-based assay, which relies on clotting and therefore cannot be performed in the absence of fibrinogen, the effect of fibrinogen $\gamma^{\prime}$ on APC resistance could be reproduced by the addition of the synthetic $\gamma^{\prime}$ chain C-terminal peptide.

Thrombin generation-based APC resistance was expressed as the residual ETP, which is the ratio of the ETPs determined in the presence and absence of APC (or TM). Fibrinogen decreased the residual ETP not only by decreasing the ETP ${ }_{+A P C}$, but also by increasing the ETP-APC. The ability of fibrinogen to increase the ETP determined at high TF in the absence of APC is a well-known effect which has been attributed to the fact that fibrin(ogen) binds thrombin and delays its inhibition by $\alpha_{2}$-macroglobulin and antithrombin [27-30], without affecting its ability to convert the fluorogenic substrate. The observation that, compared to $\gamma \mathrm{A} / \gamma \mathrm{A}$ fibrinogen, $\gamma \mathrm{A} / \gamma^{\prime}$ fibrinogen binds more thrombin with a higher affinity [29] can explain why this fibrinogen isoform is more effective than $\gamma \mathrm{A} / \gamma \mathrm{A}$ fibrinogen in increasing the ETP-APC. On the other hand, the effect on the ETP ${ }_{+A P C}$ is likely due to the ability of fibrinogen, and particularly of the $\gamma^{\prime}$ chain, to inhibit thrombin activity on FV [14] and FVIII [13], as demonstrated by the fact that this effect could be reproduced by the fibrinogen $\gamma^{\prime}$ C-terminal peptide alone. Therefore, in contrast to most determinants of APC resistance (such as FV Leiden, elevated levels of prothrombin and FVIII, as well as low protein S levels) $[6,7]$, which act by impairing FVa and/or FVIIla inactivation, the fibrinogen $\gamma^{\prime}$ chain improves the APC response by inhibiting FV and FVIII activation. This mechanism is similar to that of tissue factor pathway inhibitor, which also improves the APC response by decreasing the procoagulant drive $[6,7]$.

The thrombin generation-based APC resistance test used in our study was performed at $10 \mathrm{pM}$ TF. Since it is well established that the intrinsic FX-activating complex (i.e. FVIIla) does not contribute to thrombin generation measured at high TF concentrations [7], control experiments with anti-FVIII antibodies were performed to verify the FVIII-dependence of our thrombin generation-based APC resistance assay. These experiments showed that the addition of neutralizing anti-FVIII antibodies does not affect thrombin generation at $10 \mathrm{pM}$ TF in the absence of APC, whereas in the 
presence of APC considerably less thrombin is formed in the presence than in the absence of anti-FVIII antibodies (data not shown). This indicates that FVIII is indeed a determinant of thrombin generation measured at high TF in the presence of APC and of the residual ETP.

Importantly, the APC-sensitizing action of fibrinogen was not confined to normal plasma, but also extended to plasma from heterozygous and homozygous carriers of FV Leiden. Although $\gamma \mathrm{A} / \gamma \mathrm{A}$ and $\gamma \mathrm{A} / \gamma^{\prime}$ fibrinogen could not be tested separately on a FV Leiden background, our population study showed a definite association between FGG H2 genotype (and hence reduced fibrinogen $\gamma^{\prime}$ levels) and increased APC resistance in FV Leiden carriers. Moreover, the fibrinogen $\gamma^{\prime}$ peptide effectively decreased APC resistance in FV Leiden plasma, both in the thrombin generation- and in the APTT-based assay. These findings are in line with an in vivo study in which transgenic expression of the human $\gamma^{\prime}$ chain substituting the murine $\gamma^{\prime}$ chain reduced thrombus size in FV Leiden mice in an experimental model of venous thrombosis [31]. Addition of pre-formed APC to plasma is not entirely physiological, because it bypasses the activation of protein $C$ by the thrombin/TM complex. Since fibrinogen $\gamma^{\prime}$ could interfere with this process by binding and inhibiting thrombin, we also studied the effect of the fibrinogen $\gamma^{\prime}$ peptide on protein $C$ activation and on thrombin generation measured in the presence of (soluble) TM. We observed that the peptide markedly decreased protein C activation by the thrombin/sTM complex in a model system, suggesting that the fibrinogen $\gamma^{\prime}$ peptide affects both pro- and anticoagulant functions of thrombin. Interestingly, previous studies have shown that fibrinogen impairs APC generation by interfering with the formation of the thrombin/TM complex [32,33], which was originally attributed to the competition between fibrinogen and TM for thrombin exosite I. However, our data indicate that occupation of thrombin exosite II by the fibrinogen $\gamma^{\prime}$ peptide may contribute to this effect, as also reported in a recent abstract [34]. Nevertheless, addition of the fibrinogen $\gamma^{\prime}$ peptide still decreased thrombin generation in the presence of STM, both in normal and FV Leiden heterozygous plasma. In other words, the peptide increased the sensitivity of plasma to endogenously generated APC, suggesting that the anticoagulant effect of the peptide (inhibition of thrombin-mediated FV and FVIII activation) is stronger than its procoagulant effect (inhibition of protein $\mathrm{C}$ activation by the thrombin/sTM complex). 
In summary, our study shows that fibrinogen and particularly its $\gamma \mathrm{A} / \gamma^{\prime}$ isoform increases APC sensitivity in normal and FV Leiden plasma. This effect can be reproduced by the $\mathrm{C}$-terminal peptide of the $\gamma^{\prime}$ chain and is likely explained by the ability of the peptide to inhibit thrombin-mediated FV and FVIII activation. Although the fibrinogen $\gamma^{\prime}$ peptide also inhibits protein $C$ activation by the thrombin/TM complex, its net effect in plasma is still anticoagulant. Therefore, the fibrinogen $\gamma^{\prime}$ peptide could form the basis for pharmacological interventions to counteract APC resistance.

\section{Acknowledgements}

The authors thank O. Segers for genotyping the FV Leiden population for the FGG 10034C >T SNP. This work was supported by grant nr. 2011-2 from the Dutch Thrombosis Foundation. 


\section{References}

1. Esmon CT. The protein C pathway. Chest 2003; 124(3 Suppl): p. 26S-32S.

2. Dahlbäck B and Villoutreix BO. The anticoagulant protein C pathway. FEBS Lett 2005; 579(15): p. 3310-6.

3. Castoldi E and Rosing J. APC resistance: biological basis and acquired influences. J Thromb Haemost 2010; 8(3): p. 445-53.

4. Dahlbäck B, Carlsson M and Svensson PJ. Familial thrombophilia due to a previously unrecognized mechanism characterized by poor anticoagulant response to activated protein C: prediction of a cofactor to activated protein C. Proc Natl Acad Sci USA 1993; 90(3): p. 1004-8.

5. Bertina RM, Koeleman BP, Koster T, Rosendaal FR, Dirven RJ, de Ronde $H$, van der Velden $\mathrm{PA}$ and Reitsma PH. Mutation in blood coagulation factor $\mathrm{V}$ associated with resistance to activated protein C. Nature 1994; 369(6475): p. 64-7.

6. de Visser MC, van Hylckama Vlieg A, Tans G, Rosing J, Dahm AE, Sandset PM, Rosendaal FR and Bertina RM. Determinants of the APTT- and ETP-based APC sensitivity tests. J Thromb Haemost 2005; 3(7): p. 1488-94.

7. Dielis AW, Castoldi E, Spronk HM, van Oerle R, Hamulyak K, Ten Cate H and Rosing J. Coagulation factors and the protein $\mathrm{C}$ system as determinants of thrombin generation in a normal population. J Thromb Haemost 2008; 6(1): p. 125-31.

8. Chung DW and Davie EW. Gamma and gamma' chains of human fibrinogen are produced by alternative mRNA processing. Biochemistry 1984; 23(18): p. 4232-6.

9. Lovely RS, Moaddel $\mathrm{M}$ and Farrell $\mathrm{DH}$. Fibrinogen gamma' chain binds thrombin exosite II. J Thromb Haemost. 2003; 1(1): p. 124-31.

10. Sabo TM, Farrell DH and Maurer MC. Conformational analysis of gamma' peptide (410427) interactions with thrombin anion binding exosite II. Biochemistry 2006; 45(24): p. 7434-45.

11. Alexander KS, Fried MG and Farrell DH. Role of electrostatic interactions in binding of thrombin to the fibrinogen gamma' chain. Biochemistry 2012; 51(16): p. 3445-50.

12. Seegers $W H$, Nieft $M$ and Loomis EC. Note on the Adsorption of Thrombin on Fibrin. Science 1945; 101(2629): p. 520-1.

13. Lovely RS, Boshkov LK, Marzec UM, Hanson SR and Farrell DH. Fibrinogen gamma' chain carboxy terminal peptide selectively inhibits the intrinsic coagulation pathway. $\mathrm{Br} J$ Haematol. 2007; 139(3): p. 494-503.

14. Omarova F, Uitte De Willige $S$, Ariëns RA, Rosing J, Bertina RM and Castoldi E. Inhibition of thrombin-mediated factor $\mathrm{V}$ activation contributes to the anticoagulant activity of fibrinogen gamma'. J Thromb Haemost 2013; 11(9): p. 1669-78.

15. Lovely RS, Rein CM, White TC, Jouihan SA, Boshkov LK, Bakke AC, McCarty OJ and Farrell $\mathrm{DH}$. gammaA/gamma' fibrinogen inhibits thrombin-induced platelet aggregation. Thromb Haemost 2008; 100(5): p. 837-46. 
16. Lancellotti S, Rutella S, De Filippis V, Pozzi N, Rocca B and De Cristofaro R. Fibrinogenelongated gamma chain inhibits thrombin-induced platelet response, hindering the interaction with different receptors. J Biol Chem 2008; 283(44): p. 30193-204.

17. Uitte de Willige $S$, de Visser MC, Houwing-Duistermaat JJ, Rosendaal FR, Vos HL and Bertina RM. Genetic variation in the fibrinogen gamma gene increases the risk for deep venous thrombosis by reducing plasma fibrinogen gamma' levels. Blood 2005; 106(13): p. 4176-83.

18. Grünbacher G, Weger W, Marx-Neuhold E, Pilger E, Koppel H, Wascher T, Marz W and Renner $W$. The fibrinogen gamma (FGG) $10034 \mathrm{C}>\mathrm{T}$ polymorphism is associated with venous thrombosis. Thromb Res 2007; 121(1): p. 33-6.

19. Uitte de Willige S, Pyle ME, Vos HL, de Visser MC, Lally C, Dowling NF, Hooper WC, Bertina $\mathrm{RM}$ and Austin $\mathrm{H}$. Fibrinogen gamma gene 3 '-end polymorphisms and risk of venous thromboembolism in the African-American and Caucasian population. Thromb Haemost 2009; 101(6): p. 1078-84.

20. Nowak-Göttl U, Weiler H, Hernandez I, Thedieck S, Seehafer T, Schulte T and Stoll M. Fibrinogen alpha and gamma genes and factor VLeiden in children with thromboembolism: results from 2 family-based association studies. Blood 2009; 114(9): p. 1947-53.

21. Smalberg JH, Koehler E, Murad SD, Plessier A, Seijo S, Trebicka J, Primignani M, Rijken DC, de Maat MP, Garcia-Pagan JC, Valla DC, Janssen HL and Leebeek FW. Fibrinogen gamma' and variation in fibrinogen gamma genes in the etiology of portal vein thrombosis. Thromb Haemost 2013; 109(3): p. 558-60.

22. Segers $O$, Simioni $P$, Tormene $D$ and Castoldi $E$. Influence of single nucleotide polymorphisms on thrombin generation in factor $\mathrm{V}$ Leiden heterozygotes. Thromb Haemost 2014; 111(3): p. in press.

23. Cooper AV, Standeven KF and Ariëns RA. Fibrinogen gamma-chain splice variant gamma' alters fibrin formation and structure. Blood 2003; 102(2): p. 535-40.

24. Allan $P$, Uitte de Willige $S$, Abou-Saleh RH, Connell SD and Ariëns RA. Evidence that fibrinogen gamma' directly interferes with protofibril growth: implications for fibrin structure and clot stiffness. J Thromb Haemost 2012; 10(6): p. 1072-80.

25. Siebenlist KR, Meh DA and Mosesson MW. Plasma factor XIII binds specifically to fibrinogen molecules containing gamma chains. Biochemistry 1996; 35(32): p. 10448-53.

26. Hemker HC, Giesen P, AlDieri R, Regnault V, de Smed E, Wagenvoord R, Lecompte T and Béguin S. The calibrated automated thrombogram (CAT): a universal routine test for hyper- and hypocoagulability. Pathophysiol Haemost Thromb. 2002; 32(5-6): p. 249-53.

27. Hemker HC, Giesen P, Al Dieri R, Regnault V, de Smedt E, Wagenvoord R, Lecompte T and Beguin S. Calibrated automated thrombin generation measurement in clotting plasma. Pathophysiol Haemost Thromb 2003; 33(1): p. 4-15.

28. Duchemin J, Pan-Petesch B, Arnaud B, Blouch MT and Abgrall JF. Influence of coagulation factors and tissue factor concentration on the thrombin generation test in plasma. Thromb Haemost 2008; 99(4): p. 767-73. 
29. Fredenburgh JC, Stafford AR, Leslie BA and Weitz JI. Bivalent binding to gammaA/gamma'fibrin engages both exosites of thrombin and protects it from inhibition by the antithrombin-heparin complex. J Biol Chem 2008; 283(5): p. 2470-7.

30. Walton BL, Getz TM, Bergmeier W, Lin FC, Uitte de Willige S and Wolberg AS. The fibrinogen gammaA/gamma' isoform does not promote acute arterial thrombosis in mice. J Thromb Haemost 2014; 12(5): p. 680-9.

31. Mosesson MW, Cooley BC, Hernandez I, Diorio JP and Weiler H. Thrombosis risk modification in transgenic mice containing the human fibrinogen thrombin-binding gamma' chain sequence. J Thromb Haemost. 2009; 7(1): p. 102-10.

32. Jakubowski HV and Owen WG. Macromolecular specificity determinants on thrombin for fibrinogen and thrombomodulin. J Biol Chem 1989; 264(19): p. 11117-21.

33. Diez N, Montes R, Alonso A, Medina P, Navarro S, Espana F and Hermida J. Association of increased fibrinogen concentration with impaired activation of anticoagulant protein $C$. $J$ Thromb Haemost 2006; 4(2): p. 398-402.

34. Ramsey JP, Ashtekar AS, Farrell DH and Lovely RS. Fibrinogen Gamma' Carboxyl Terminus Inhibits Thrombin Cleavage of Protein C. FASEB J. 2011; 25. Abstract 637.3. 



\section{Chapter 4}

Effects of negatively charged phospholipids and the fibrinogen $\gamma^{\prime}$ C-terminal peptide on factor $\mathbf{X I}$ activation by thrombin

Farida Omarova, Jan Rosing, Rogier M. Bertina, Elisabetta Castoldi In preparation 


\begin{abstract}
Introduction. Coagulation factor XI (FXI) is the zymogen of the serine-protease FXla, which contributes to thrombin formation by activating FIX. In vitro, FXI activation by thrombin is highly inefficient, unless stimulated by negatively charged surfaces. Here we have studied the effects of ionic strength, phospholipid vesicles and aptamers targeting thrombin exosites on FXI activation by thrombin. The ultimate goal was to test whether fibrinogen $\gamma^{\prime}$, which binds to thrombin exosite II, affects thrombincatalyzed FXI activation. Materials and methods. FXI was incubated with thrombin in the absence and presence of phospholipid vesicles and FXla generation was quantified with a chromogenic substrate. The ionic strength was varied using either $\mathrm{NaCl}$ or tetrapropylammonium chloride. Binding of thrombin and FXI to phospholipids was determined by surface plasmon resonance. The involvement of thrombin exosites in FXI activation was studied using thrombin aptamers targeting exosite I and exosite II and a synthetic fibrinogen $\gamma^{\prime}$ peptide. Results. Decreasing the ionic strength greatly stimulated FXI activation by thrombin. However, at equal ionic strength, the reaction was more efficient with $\mathrm{NaCl}$ than with tetrapropylammonium chloride, suggesting a specific stimulatory effect of $\mathrm{Na}^{+}$. Phospholipid vesicles containing negatively charged phospholipids enhanced FXI activation by thrombin. Thrombin and FXI bound to negatively charged phospholipid vesicles and both thrombin exosites contributed to phospholipid binding. The fibrinogen $\gamma^{\prime}$ peptide inhibited thrombin-mediated FXI activation in a dose-dependent manner, both in the absence and presence of phospholipids. Conclusions. Thrombin-mediated FXI activation is stimulated by negatively charged phospholipids and inhibited by the fibrinogen $\gamma^{\prime}$ peptide.
\end{abstract}




\section{Introduction}

Coagulation factor $\mathrm{XI}(\mathrm{FXI})$ is the zymogen of FXla, an enzyme of the contact system that participates in coagulation by activating factor IX [1] and possibly also factor $X$ and factor $V$ [2]. FXI circulates in plasma at a concentration of $\sim 30 \mathrm{nM}$, virtually all bound to high molecular weight kininogen $[1,3]$. Structurally, FXI is a $160-k D a$ disulfide-linked homodimer, each monomer consisting of four apple domains and a catalytic serine-protease domain $[4,5]$. FXI is not a vitamin K-dependent protein and lacks the $\mathrm{Ca}^{2+}$-binding Gla-domain.

FXI is activated by FXIla, thrombin and FXla (auto-activation) via cleavage of the $\mathrm{Arg}^{369}$ - $11 \mathrm{e}^{370}$ peptide bond between apple domain 4 and the catalytic domain of FXI [58]. Although FXIla is the main activator of FXI, it has been shown that thrombinmediated activation of FXI also occurs in plasma [6,9]. According to the revised model of blood coagulation [7], traces of thrombin formed during the initiation phase activate $\mathrm{FXI}$, amplifying thrombin generation and leading to the activation of thrombin activatable fibrinolysis inhibitor, which in turn prevents the lysis of the clot [10-12]. The physiological relevance of this feedback mechanism is illustrated by the bleeding tendency associated with FXI deficiency, which manifests itself particularly in tissues with high fibrinolytic activity [13].

In model systems FXI activation by thrombin is remarkably inefficient, but can be greatly stimulated by negatively charged surfaces, such as dextran sulfate [7], heparin [14], sulfatides [6] and polyphosphate [15], which provide a template for the bidimensional interaction between thrombin and FXI. The same polyanions have also been shown to favor auto-activation of FXI by FXIa [5,14-16]. In vivo, FXI activation by thrombin is thought to occur at the surface of activated platelets $[17,18]$, where glycoprotein Ib $\alpha$ (GPIb $\alpha$ ) may act as a cofactor [19,20], as both thrombin and FXI bind to (distinct sites on) this receptor [21]. Additional physiological cofactors may be platelet polyphosphate [15] as well as factor $V a$ (FVa), which has been reported to stimulate thrombin-mediated FXI activation 2-4 times in a phospholipid-dependent manner [22].

Thrombin activity is regulated by a $\mathrm{Na}^{+}$-binding site that is located in a region important for the formation of the substrate binding pocket [23]. It is thought that $\mathrm{Na}^{+}$-binding allosterically regulates thrombin by converting it from an anticoagulant ("slow") to a procoagulant ("fast") form with a higher affinity for procoagulant 
substrates [24-26]. More recent structural insights suggest that "slow" thrombin is a dynamic zymogen-like form, which is stabilized in the active conformation by $\mathrm{Na}^{+}$binding $[27,28]$. However, it is still unclear whether and how $\mathrm{Na}^{+}$binding affects the activity of thrombin towards FXI.

The interactions of thrombin with its many substrates and cofactors are mediated by two anion-binding exosites [29]. Using thrombin variants with mutations in exosite I or II, it was shown that both exosites participate in FXI activation, exosite I by binding FXI and exosite II by binding DXS or platelet GPIb $\alpha[19,20]$. However, these papers were later partially retracted and the involvement of exosite I in FXI activation has recently been questioned [30].

The alternatively spliced fibrinogen $\gamma^{\prime}$ chain, which is present in $8-15 \%$ of all fibrinogen molecules, binds to thrombin exosite II with high affinity via its C-terminal end [31]. This interaction interferes with the activity of thrombin towards some of its substrates, including the platelet protease-activated receptor (PAR)-1 [32,33], as well as factor V [34], factor VIII [35] and protein C [36]. Whether the interaction between fibrinogen $\gamma^{\prime}$ and thrombin also affects FXI activation has not been determined.

Here we have investigated the role of $\mathrm{Na}^{+}$, negatively charged phospholipids, thrombin exosites and fibrinogen $\gamma^{\prime}$ in FXI activation by thrombin.

\section{Materials and methods}

\section{Materials}

Purified human FXI, FXla and $\alpha$-thrombin were purchased from Haematologic Technologies (Essex Junction, VT, USA). FXI and FXla concentrations were calculated from the A280 determined on a NanoDrop 2000 (Thermo Scientific, Wilmington, DE, USA) using the extinction coefficients provided by Haematologic Technologies. Recombinant hirudin was obtained from Hyphen BioMed (Neuville sur Oise, France). Bovine serum albumin (BSA) was from MP Biomedicals (Illkirch, France). Dextran sulfate (DXS, MW 500,000) from Sigma-Aldrich (St. Louis, MO, USA) was a kind gift of Dr. J.W. Govers-Riemslag and purified medium-size polyphosphate (PolyP, 70mer), was a generous gift of Prof. J.H. Morrissey. Synthetic phospholipids, including 1,2dioleoyl-sn-glycero-3-phosphocholine (PC), 1,2-dioleoyl-sn-glycero-3-phosphoserine (PS), 1,2-diacyl-sn-glycero-3-phosphate (PA), sphingomyelin and cholesterol, were purchased from Avanti Polar Lipids (Alabaster, AL, USA) and resuspended in 
chloroform/methanol. The phospholipid stocks were mixed in the required proportions, dried under moderate nitrogen flow and resuspended in Hepes/ $\mathrm{NaCl}$ buffer. Phospholipid vesicles were prepared by sonication of this mixture for 10 minutes, as described [37]. The chromogenic substrate Biophen CS-21(66) was from Hyphen BioMed. $\mathrm{NaCl}$ was obtained from Sigma-Aldrich and tetrapropylammonium chloride was purchased from Acros Organics (Geel, Belgium). All Biacore reagents were from GE Healthcare (Pittsburgh, PA, USA). Single-stranded DNA oligonucleotides (aptamers) binding to thrombin exosite I (HD1, 5'-GGTTGGTGTGGTTGG3') and exosite II (HD22, 5'-AGTCCGTGGTAGGGCAGGTTGGGGTGACT-3'), respectively [38], were obtained from Integrated DNA Technologies (Leuven, Belgium). A synthetic peptide with the same sequence as the C-terminus of the fibrinogen $\gamma^{\prime}$ chain (WT-S12, Ac-VRPEHPAETEYDSLYPEDDL-OH) and a scrambled control peptide (SCR-S12, AcDESELDAYTPLPRPVEDHYE-OH) were obtained from Pepscan (Lelystad, The Netherlands). Both peptides were sulfated on both tyrosine residues, as described previously [34].

\section{FXI activation assay}

Purified human FXI (30 nM) was activated with $10 \mathrm{nM}$ human thrombin (in the absence of negatively charged surface) or $1 \mathrm{nM}$ human thrombin (in the presence of negatively charged surface) at $37^{\circ} \mathrm{C}$ in $25 \mathrm{mM}$ HEPES, $\mathrm{pH} 7.7$ at room temperature, $10-140 \mathrm{mM} \mathrm{NaCl}$ (or 0-130 mM tetrapropylammonium chloride on top of $10 \mathrm{mM} \mathrm{NaCl}$ coming from reagents), and $5 \mathrm{mg} / \mathrm{mL}$ bovine serum albumin. Some reactions were performed in the presence of $0-20 \mu \mathrm{M}$ phospholipid vesicles (PA/PC or PS/PC in various proportions), 0-20 $\mu \mathrm{M}$ thrombin aptamers or 0-100 $\mu \mathrm{M}$ fibrinogen $\gamma^{\prime}$ peptides. At regular time points aliquots of $25 \mu \mathrm{L}$ were taken from the activation mixture and transferred to the well of a microtiter plate with $200 \mu \mathrm{L}$ of a buffer containing $50 \mathrm{mM}$ Tris (pH 7.9 at room temperature), $175 \mathrm{mM} \mathrm{NaCl}, 20 \mathrm{mM}$ EDTA, $0.5 \mathrm{mg} / \mathrm{ml}$ ovalbumin, supplemented with $5 \mathrm{nM}$ hirudin to prevent further activation of FXI by thrombin. Subsequently, $25 \mu \mathrm{L}$ of the chromogenic substrate Biophen CS-21(66) was added (final concentration in the well $500 \mu \mathrm{M}$ ) and the conversion of chromogenic substrate, which is a measure for the amount of FXIa present, was followed at $405 \mathrm{~nm}$ in an Ultra Microplate Reader (Bio-Tek, Burlington, VT). The amount of FXla present in the activation mixtures was calculated using a calibration curve determined with known concentrations of FXla. 


\section{Surface plasmon resonance experiments}

Binding of $\mathrm{FXI}$ and thrombin to phospholipids at $25^{\circ} \mathrm{C}$ was determined by surface plasmon resonance (SPR) using the Biacore T200 system (GE Healthcare). Phospholipid vesicles (40/60 PS/PC mol/mol) prepared by sonication were extruded through a liposome extruder with a 200-nm filter (Avestin Europe GmbH, Mannheim, Germany) and immobilized on a L1 sensor chip (GE Healthcare) to 5000 resonance units. The reference cell was coated with vesicles containing PC only. Increasing concentrations of thrombin (0-1000 nM) or FXI (0-100 nM) in 25 mM HEPES, pH 7.4, and $20 \mathrm{mM} \mathrm{NaCl}$ were perfused for $400 \mathrm{sec}$ at a flow rate of $5 \mu \mathrm{l} / \mathrm{min}$ over the phospholipid surface and binding was recorded. After each run, the sensor chip was regenerated with $50 \mathrm{mM} \mathrm{NaOH}$. FVIII (Kogenate ${ }^{\circledR}$ FS antihemophilic factor, Bayer AG, Leverkusen, Germany), which binds to negatively charged phospholipids in the absence of $\mathrm{Ca}^{2+}$, was used as a positive control. Raw data were corrected for blank, as a detailed binding kinetics analysis is problematic to perform due to the shapes of the curves.

\section{Results}

\section{Set-up of model systems to study FXI activation by thrombin}

Thrombin-catalyzed FXI activation is a rather slow reaction in vitro $[5-7,14]$ which can be accelerated by negatively charged surfaces as well as by lowering the ionic strength $[6,14,15]$. In order to find reaction conditions that allow reliable measurement of FXI activation, we performed thrombin titrations and $\mathrm{NaCl}$ titrations of $\mathrm{FXI}$ activation in the absence and presence of negatively charged surfaces (DXS and polyP). In the absence of a negatively charged surface the rate of FXI activation increased $\sim 10$-fold when the salt concentration in the reaction medium was decreased from $140 \mathrm{mM}$ to $10 \mathrm{mM} \mathrm{NaCl}$ (Figure 4.1A).

FXI activation in the presence of a negatively charged surface can be complicated by the occurrence of auto-activation [6] as well as auto-inactivation (autolysis) of FXIa $[7,15]$. Since auto-activation and auto-inactivation particularly occur at low salt concentrations, experiments in the presence of negatively charged surfaces were performed at 50-60 mM NaCl. Moreover, the contributions of auto-activation and auto-inactivation were minimized by calculating rates of thrombin-catalyzed FXI 
activation from the linear part of time courses of FXla generation. Figure 4.1 shows the effects of different concentrations DXS (Figure 4.1B) and PolyP (Figure 4.1C). The highest concentrations of DXS $(100 \mathrm{ng} / \mathrm{mL})$ and PolyP $(100 \mathrm{nM})$ enhanced the rates of thrombin-catalyzed FXI activation 10 to 15 -fold.

Based on these experiments, we chose to use $10 \mathrm{nM}$ thrombin and $20 \mathrm{mM} \mathrm{NaCl}$ to measure $\mathrm{FXI}$ activation in free solution, and $1 \mathrm{nM}$ thrombin and $60 \mathrm{mM} \mathrm{NaCl}$ to measure FXI activation in the presence of negatively charged surfaces. The FXI concentration was set at $30 \mathrm{nM}$ in all experiments.

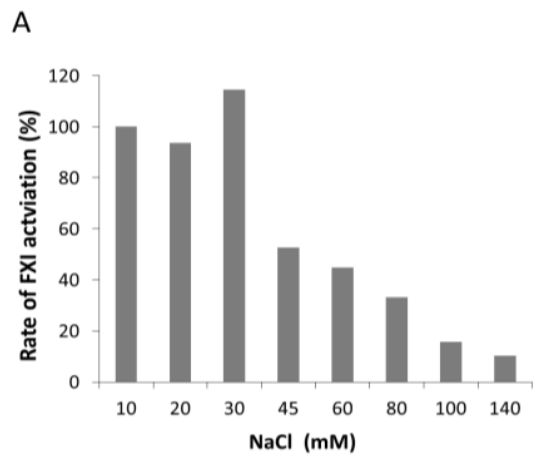

B

C
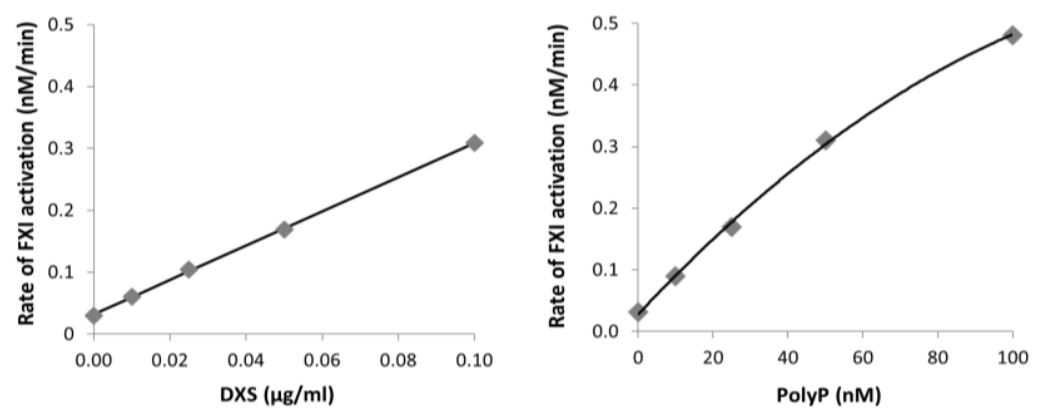

Figure 4.1 Set-up of model systems to study FXI activation by thrombin. FXI (30 nM) was incubated with $10 \mathrm{nM}$ thrombin in HEPES buffer containing 10-140 $\mathrm{mM} \mathrm{NaCl}(\mathrm{A})$. FXI (30 nM) was incubated with $10 \mathrm{nM}$ thrombin in the presence of $0-0.1 \mu \mathrm{g} / \mathrm{ml}$ DXS (A) or 0-100 nM PolyP (B) in HEPES buffer containing $50 \mathrm{mM} \mathrm{NaCl}$. FXI activation was followed in time as described under Methods. Initial rates of FXI activation ( $\mathrm{nM} \mathrm{FXIa/min)} \mathrm{were} \mathrm{determined} \mathrm{from} \mathrm{the} \mathrm{first} 5$ minutes of the reaction and plotted as a function of DXS concentration (B) or PolyP concentration (C). Averages of duplicate experiments are shown. 


\section{Effect of phospholipids on FXI activation by thrombin}

It is well established that activation of FXI by thrombin is enhanced by negatively charged surfaces like heparin, DXS and polyphosphate $[6,14,15]$. Since a phospholipid surface composed of phosphatidic acid (PA) contains a regular array of phosphate groups just as polyphosphate, we hypothesized that phospholipid vesicles containing PA might also stimulate FXI activation by thrombin. When FXI was activated with $1 \mathrm{nM}$ thrombin at $60 \mathrm{mM} \mathrm{NaCl}$, PA-containing phospholipid vesicles considerably enhanced FXI activation in a dose-dependent manner (Figure 4.2A, C). Phospholipid vesicles containing phosphatidylserine (PS), a more common component of natural phospholipid membranes, also stimulated FXI activation by thrombin (Figure 4.2B), but the effect was less pronounced than observed with PA/PC vesicles (Figure 4.2C). At a fixed concentration of phospholipid vesicles $(20 \mu \mathrm{M})$, the rate of $\mathrm{FXI}$ activation increased at increasing molar concentrations of PA and PS in the phospholipid vesicles (Figures 4.2D, E). These results show that negatively charged phospholipids, such as PA and PS, enhance FXI activation by thrombin. In contrast, no effect or only a very modest effect (less than 2-fold stimulation) was observed with phospholipid vesicles containing cholesterol and/or sphingomyelin mixed with PC (data not shown), suggesting that the effect of PA and PS is relatively specific. Inclusion of $\mathrm{Ca}^{2+}$ in the reaction mixture strongly inhibited thrombin-mediated FXI activation in the presence of phospholipid vesicles (data not shown). 

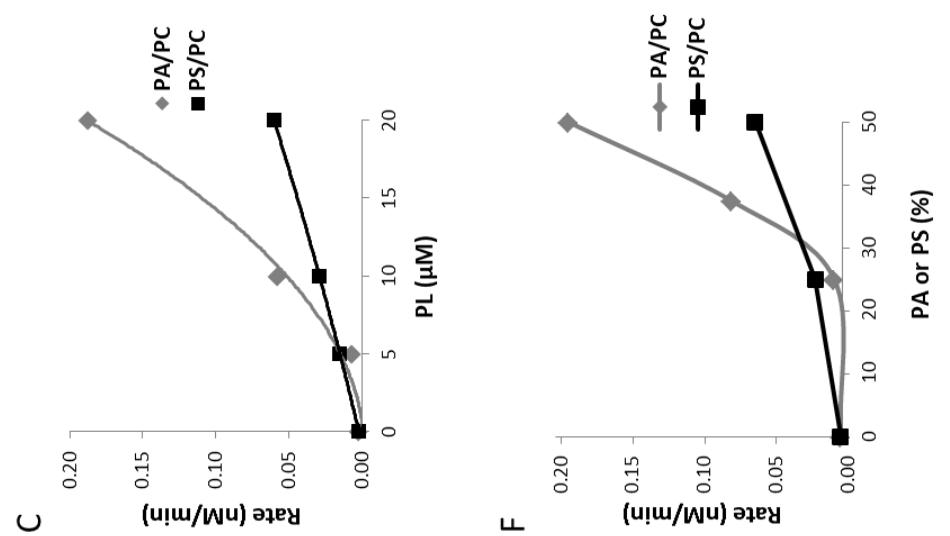

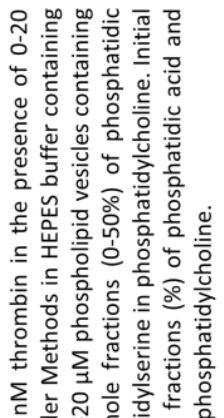

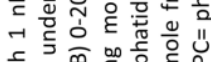

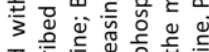

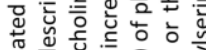

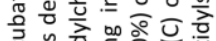

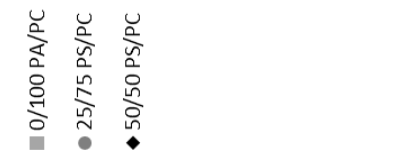

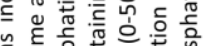

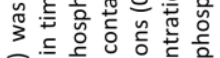

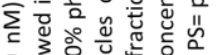

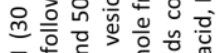

$\bar{x}$ 元

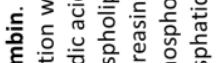

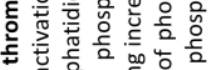

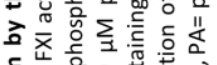

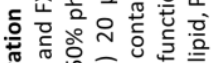

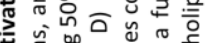

‡

$\infty$

(wu) elXJ

ш

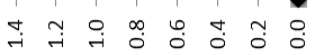

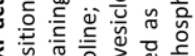

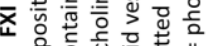

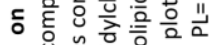
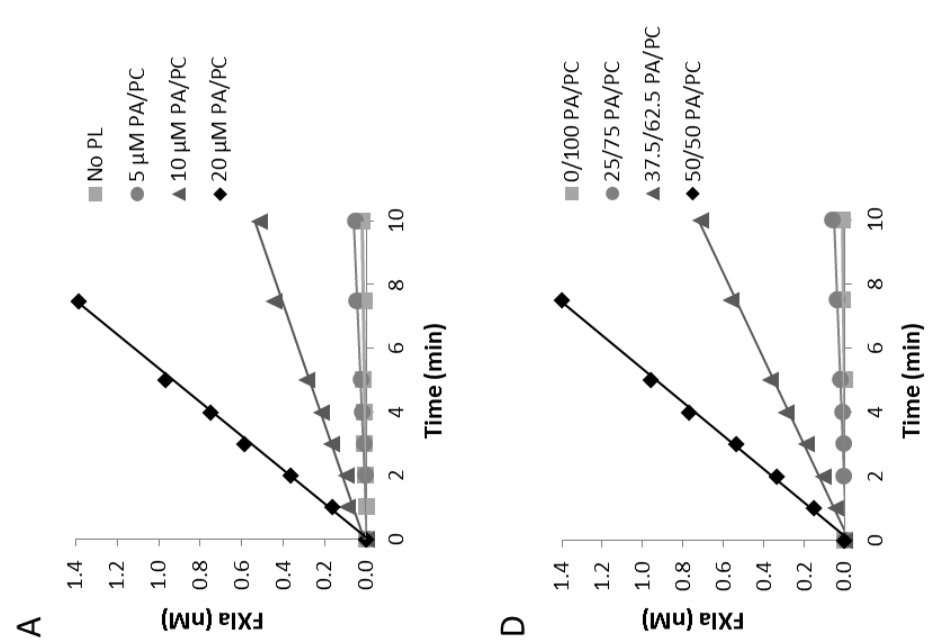

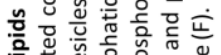

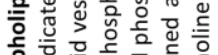

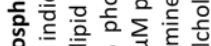

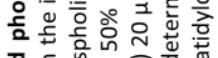

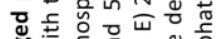

แั้

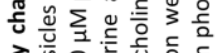

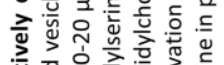

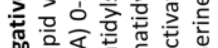

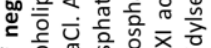

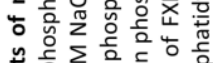

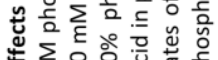

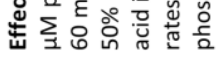

ำ 


\section{Binding of FXI and thrombin to phospholipids}

Based on the finding that phospholipids stimulate thrombin-mediated FXI activation, we hypothesized that both thrombin and FXI bind to phospholipids. This hypothesis was tested using SPR technology by perfusing thrombin (0-1000 nM) or FXI (0-100 nM) over a sensor chip coated with phospholipid vesicles (40/60 PS/PC). To favor electrostatic interactions between protein and phospholipid, the binding experiments were performed at a low ionic strength $(20 \mathrm{mM} \mathrm{NaCl})$. Both thrombin (Figure 4.3A) and FXI (Figure 4.3B) bound to the immobilized phospholipids in a dose-dependent manner, confirming that phospholipids may provide a surface that enhances FXI activation by thrombin. The binding experiments were also performed using a running buffer with $150 \mathrm{mM} \mathrm{NaCl}$. In accordance with the FXI activation data, increasing the $\mathrm{NaCl}$ concentration substantially inhibited binding of both thrombin and FXI to phospholipids.

To check whether the binding of thrombin to phospholipids is mediated by thrombin exosites, we repeated the binding experiments in the presence of aptamers that bind specifically to thrombin exosite I (HD1) [39] or thrombin exosite II (HD22) [38]. Both aptamers markedly decreased the binding, indicating that thrombin exosites I and II both contribute to the binding of thrombin to the phospholipid surface (data not shown).

A

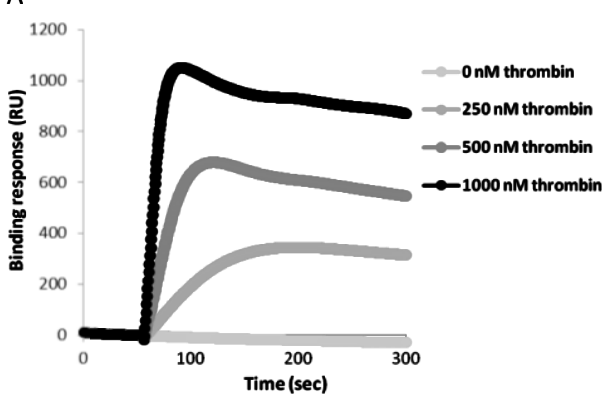

B

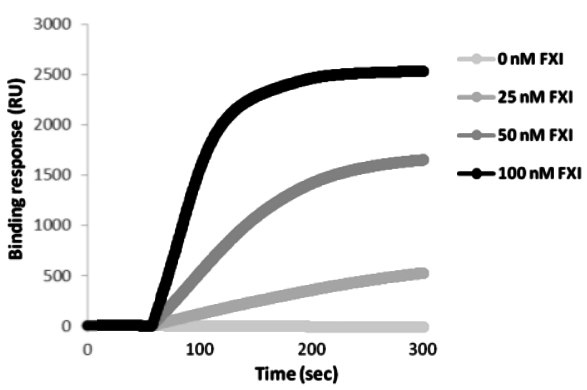

Figure 4.3 Binding of thrombin and FXI to phospholipids. Extruded phospholipid vesicles (40/60 PS/PC) were immobilized on a L1 chip. Increasing concentrations of thrombin (0-1000 nM) (A) or FXI (0-100 nM) (B) were perfused over the chip and the binding response was recorded as described under Methods. 


\section{Involvement of thrombin exosites in FXI activation}

To determine the role of each thrombin exosite in thrombin-mediated FXI activation, increasing concentrations of either aptamer were added to FXI activation mixtures in the absence and presence of $20 \mu \mathrm{M} 50 / 50$ PS/PC. In free solution, aptamer HD1 hardly influenced FXI activation (Figure 4.4A), while aptamer HD22 inhibited the reaction in a dose-dependent manner (Figure 4.4B). In the presence of phospholipids, HD1 had a moderate inhibitory effect (Figure 4.4D), whereas HD22 potently inhibited FXI activation by thrombin (Figure 4.4E). This is in line with the observation that both aptamers inhibited thrombin binding to phospholipids in the binding assay. The $\mathrm{IC}_{50}$ of HD22 in the absence of phospholipids was $\sim 8.3 \mu \mathrm{M}$ and the $\mathrm{IC}_{50}$ values in the presence of phospholipids were $0.16 \mu \mathrm{M}$ for HD1, which partially inhibits FXI activation, and $<0.04 \mu \mathrm{M}$ for HD22 (Figure 4.4C, F).

\section{Effect of the fibrinogen $\gamma^{\prime}$ peptide on FXI activation by thrombin}

To test whether the fibrinogen $\gamma^{\prime}$ C-terminal peptide affects thrombin-catalyzed FXI activation, FXI was activated with thrombin in the absence and presence of $20 \mu \mathrm{M}$ $50 / 50$ PS/PC phospholipid vesicles, and in the presence of varying concentrations (0-100 $\mu \mathrm{M})$ of the fibrinogen $\gamma^{\prime}$ peptide (WT-S12) or scrambled control peptide (SCR-S12). WT-S12 inhibited FXI activation by thrombin both in the absence and in the presence of phospholipids (Figure 4.5A, D), whereas SCR-S12 was much less effective (Figure 4.5B, E). The concentration of WT-S12 peptide giving half-maximal inhibition (IC $\mathrm{C}_{50}$ ) was $8.7 \mu \mathrm{M}$ in the absence of phospholipids and $15.8 \mu \mathrm{M}$ in the presence of phospholipids, while the $\mathrm{IC}_{50}$ of SCR-S12 was $>100 \mu \mathrm{M}$ both in the absence and presence of phospholipids (Figure 4.5C, F). This demonstrates that WT-S12 is at least 7 times more effective than the SCR-S12 peptide in inhibiting thrombin-mediated FXI activation both in the absence and presence of phospholipid vesicles. 

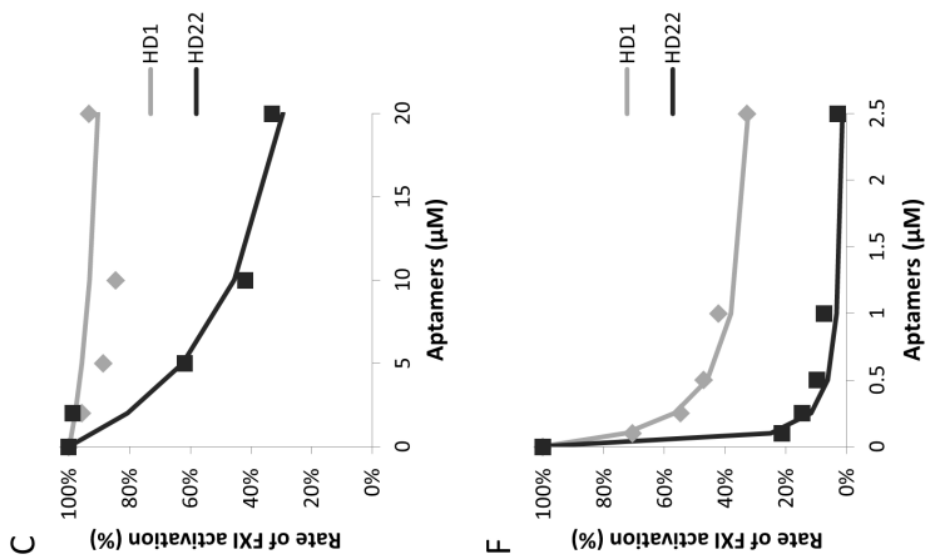

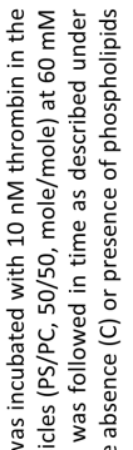

แ

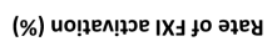
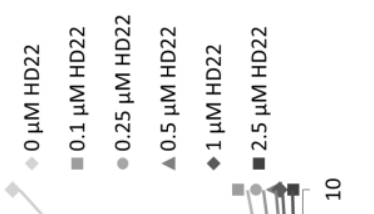

$\sum_{i}$

응

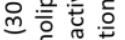

준 응 잔

븡 등.

응 $\sum_{1}^{\circ}$

듬유 ํำ

参苍全究

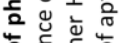

\% 焉

这总

政

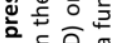

ฮั

ष हैं

这인음

당

表势

돈

ш

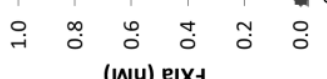

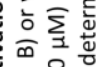

ษั

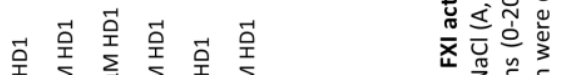

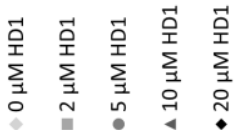
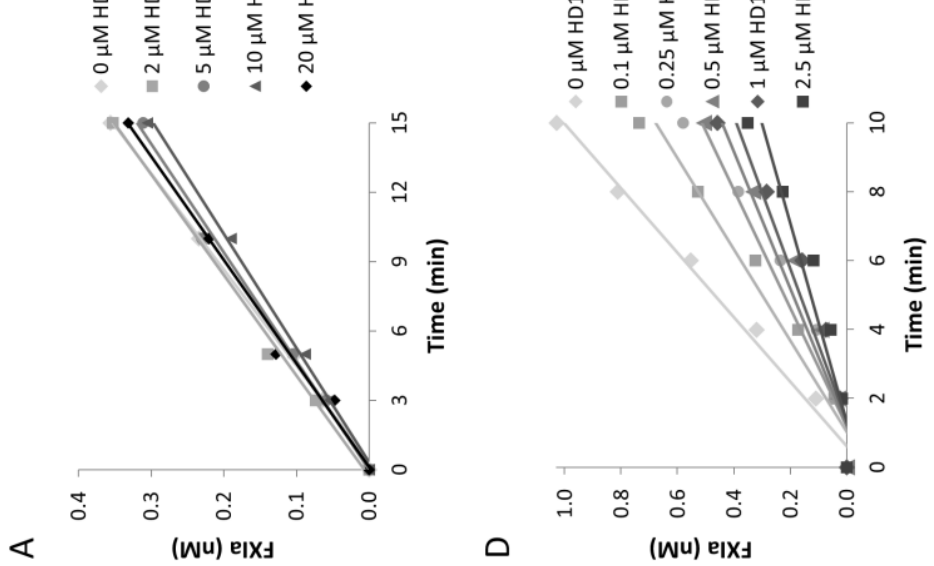

告

○ (wu) eIXJ 

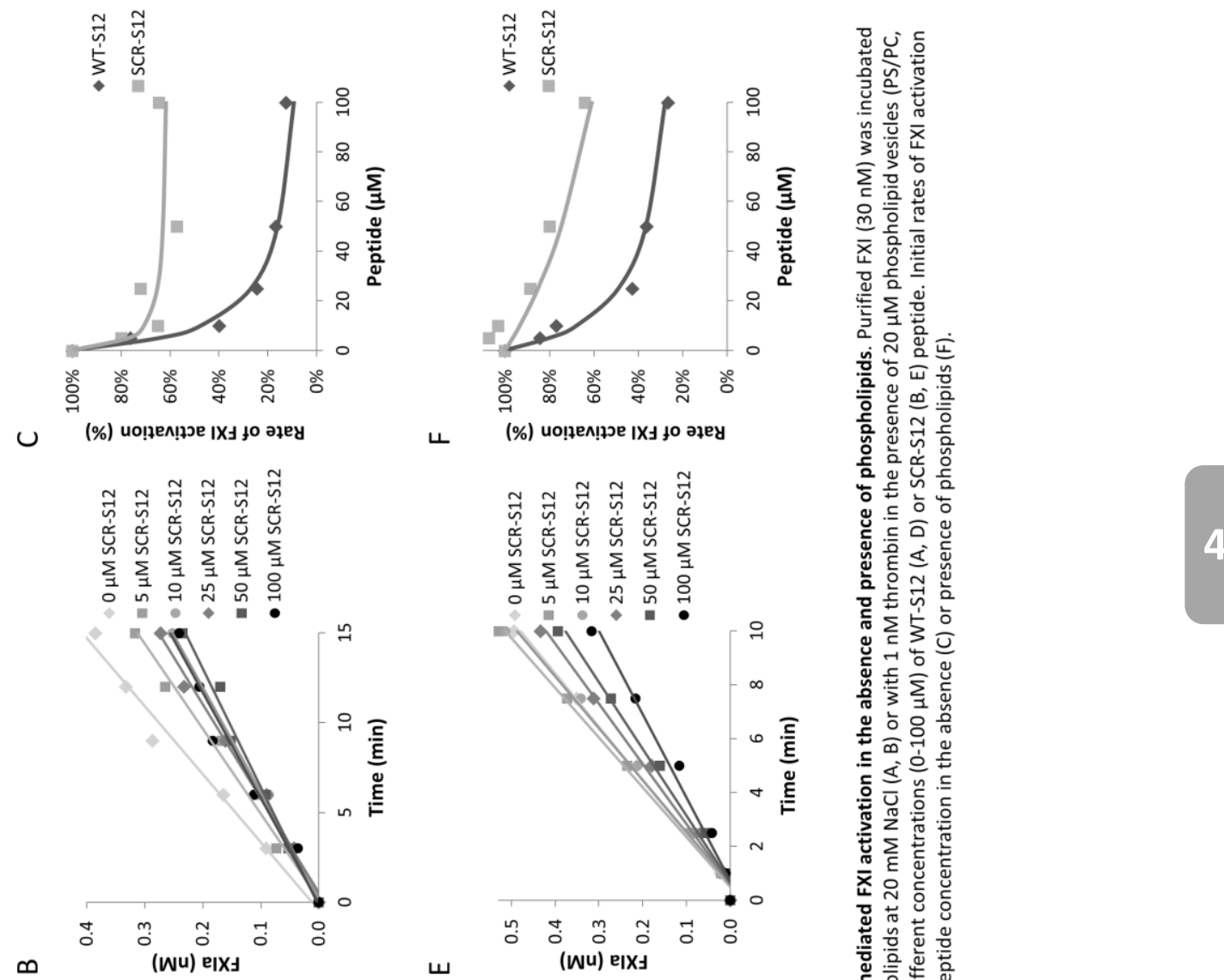

丩
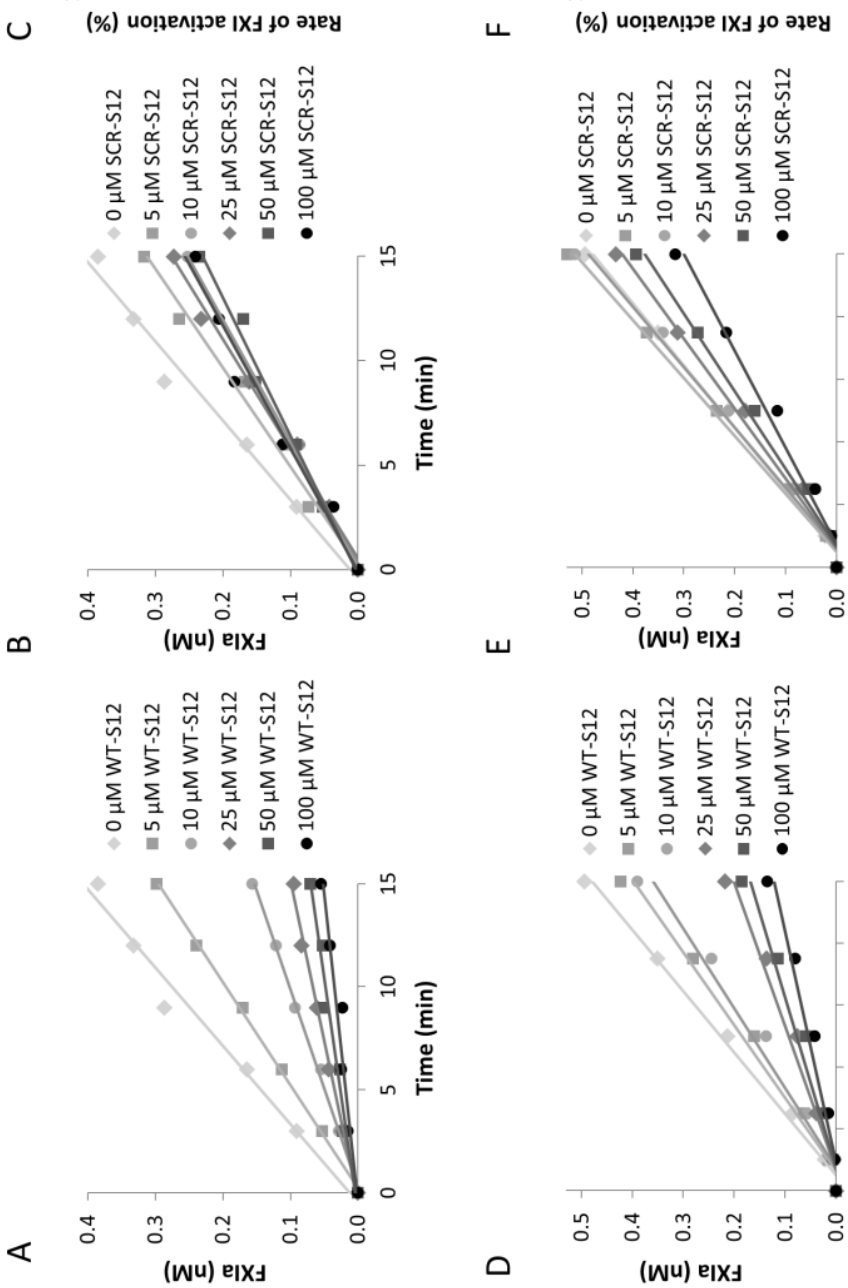

ш

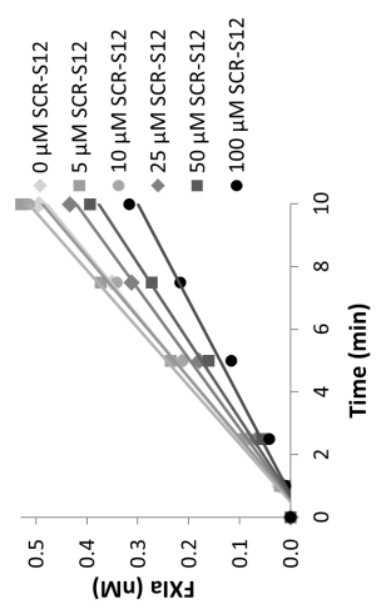

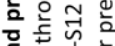

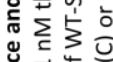

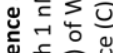

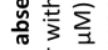

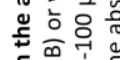

.

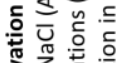

至 $\sum^{\pi}$

不

훙

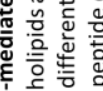

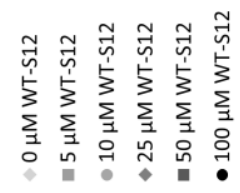

층 은

흥도은

额药

ธ ษับำ

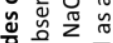

융 谙

동으음

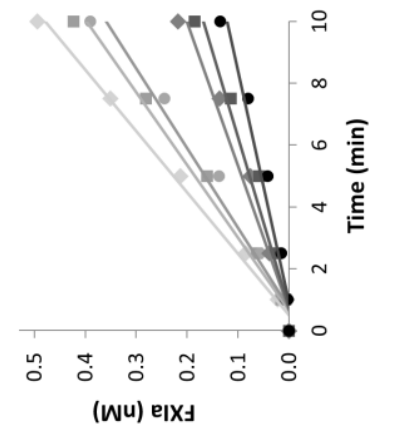



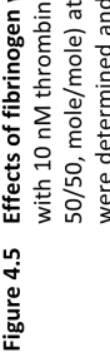




\section{Effect of $\mathrm{NaCl}$ and ionic strength on $\mathrm{FXI}$ activation by thrombin}

The well-established influence of $\mathrm{NaCl}$ concentration on thrombin-catalyzed $\mathrm{FXI}$ activation $[6,14,15]$ could be a $\mathrm{Na}^{+}$-specific effect mediated by the occupation of the $\mathrm{Na}^{+}$-binding site of thrombin or a more general effect of ionic strength on the electrostatic interactions between thrombin and FXI and/or negatively charged surfaces. In order to distinguish between these two possibilities, we varied the ionic strength in the activation mixture using either $\mathrm{NaCl}$ or tetrapropylammonium chloride, whose cation $\left(\left(\mathrm{CH}_{3} \mathrm{CH}_{2} \mathrm{CH}_{2}\right)_{4} \mathrm{~N}^{+}\right)$is much bulkier than $\mathrm{Na}^{+}$and does not fit in the $\mathrm{Na}^{+}$-binding pocket of thrombin. In both cases, increasing the salt concentration from $10 \mathrm{mM}$ to physiological $(140 \mathrm{mM})$ resulted in a progressive decrease of the FXI activation rate, both in the absence (Figure 4.6A, B) and in the presence of phospholipids (Figure 4.6D, E). However, at any given value of ionic strength, the rate of $\mathrm{FXI}$ activation was higher in the presence of $\mathrm{NaCl}$ than in the presence of tetrapropylammonium chloride (Figure 4.6C, F). This suggests that $\mathrm{Na}^{+}$, in addition to its inhibitory effect associated with preventing electrostatic interactions between thrombin, FXla and negatively charged surface, has a specific stimulatory effect, probably mediated by occupation of the $\mathrm{Na}^{+}$-binding site on thrombin. 


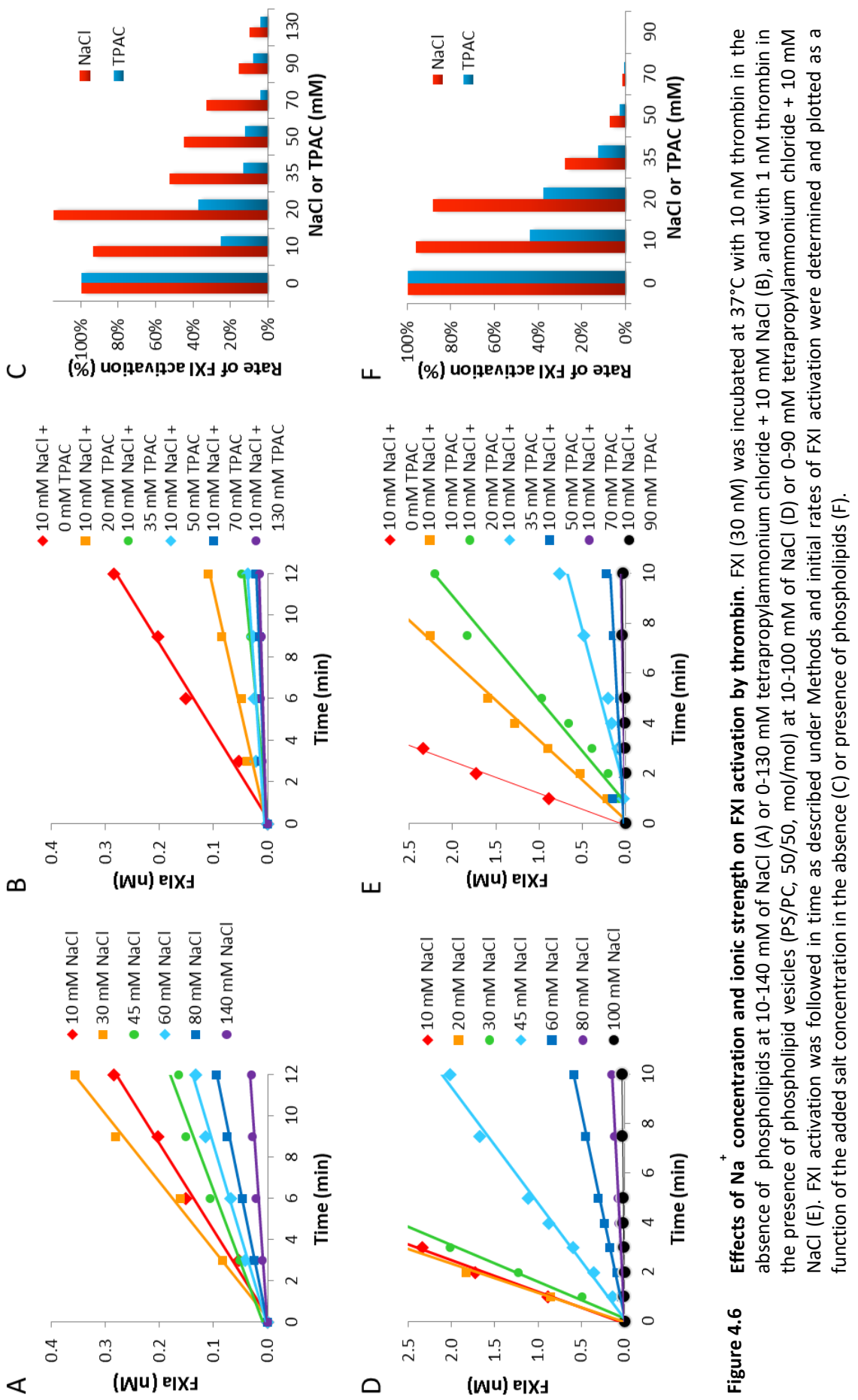




\section{Discussion}

Although it has been known for a long time that thrombin activates $\mathrm{FXI}$, several aspects of this reaction have remained enigmatic, raising doubts on its physiological importance [40]. Therefore, we have set up an in vitro model system to investigate thrombin-catalyzed FXI activation and its requirements in terms of cofactors, ionic strength and involvement of thrombin exosites. Moreover, we have investigated the effect of the fibrinogen $\gamma^{\prime}$ peptide, which has been previously shown to inhibit other thrombin functions, on thrombin-mediated FXI activation. This information may be useful in view of the recently revived interest in FXI as a promising target for anticoagulant therapy [41-43].

FXI activation by thrombin is a rather slow reaction that is considerably enhanced at low ionic strength and in the presence of negatively charged surfaces such as DXS and PolyP $[7,14,15]$. Since these surfaces bind both thrombin [44-46] and FXI [5], they likely act as a template that brings both proteins in close proximity and promotes their interaction and reaction $[6,15]$. Here we demonstrate that negatively charged phospholipids, such as PA and PS, also stimulate FXI activation. This effect was more pronounced for PA than for PS and was only appreciable with phospholipid vesicles containing $25 \%$ or more PA or PS. In contrast, hardly any stimulation was observed with vesicles containing neutral lipids like cholesterol and/or sphingomyelin. The latter were intended to mimic lipid rafts, as FXI has been reported to localize on lipid rafts when bound to GPIb $\alpha$ on the surface of activated platelets [47]. Although the effect of negatively charged phospholipids on thrombin-catalyzed FXI activation has been investigated before, no stimulation was observed in previous studies $[6,22,48]$. This discrepancy may be due to the low percentage (20\%) of PS used in those studies, which would result in only minimal stimulation and/or to the inclusion of $\mathrm{Ca}^{2+}$ in the reaction mixture which in our hands severely abolished the effect of phospholipids on FXI activation by thrombin.

In an attempt to explain the stimulatory effect of PA and PS, we hypothesized that FXI and thrombin bind to negatively charged phospholipids. Indeed, both thrombin and FXI showed dose-dependent binding to immobilized phospholipid vesicles with a high PS content (40/60 PS/PC) in direct binding assays. Since PS is a key component of activated platelet membranes, it is tempting to speculate that platelet phospholipids might serve as a physiological surface for thrombin-mediated FXI activation in vivo. 
However, it should be emphasized that the experimental conditions (low ionic strength, no $\mathrm{Ca}^{2+}$ ) at which we observed binding of thrombin and FXI to phospholipids are far from physiological, and that binding was abolished at physiological $\mathrm{NaCl}$ concentration (140 mM). Accordingly, a previous study where binding of thrombin and FXI/FXIa to 20/40/40 PS/PE/PC phospholipids immobilized on a polyacrylamide column was probed at physiological $\mathrm{NaCl}$ and $\mathrm{Ca}^{2+}$ concentrations failed to detect any binding [48].

Since thrombin and FXI both lack a lipid-binding Gla-domain, it is unclear how they bind to negatively charged phospholipids, but the $\mathrm{NaCl}$ effect strongly suggests that electrostatic interactions play an important role. For FXI we do not know which domain(s) may be involved. With respect to thrombin, experiments with aptamers targeting the two anion-binding exosites of thrombin indicated that both exosites participate in phospholipid binding. This is in line with our functional experiments, showing that thrombin-catalyzed FXI activation in the presence of phospholipids is inhibited both by aptamer HD1 (targeting exosite I) and by aptamer HD22 (targeting exosite II). However, in the absence of phospholipids, FXI activation by thrombin was only affected by the aptamer against exosite II. That thrombin exosite I is not required for FXI activation by thrombin and is not involved in the thrombin-FXI interaction, is in agreement with the observation that $\beta$-thrombin and $\nu$-thrombin, which lack a fully formed exosite I, are able to activate FXI in plasma [2]. Taken together, our results suggest a model in which both exosites contribute to thrombin binding to phospholipids (with a predominance of exosite II), while exosite II might also be involved in the interaction with FXI.

Furthermore, we show here that the fibrinogen $\gamma^{\prime}$ peptide inhibits FXI activation by thrombin, both in the absence and in the presence of negatively charged phospholipids. This can be explained by the fact that the peptide disrupts the interaction between phospholipid and thrombin exosite II, which is in line with the data on exosite requirement. However, the peptide also inhibited FXI activation in the absence of negatively charged surface, which confirms that thrombin exosite II is also involved in the interaction with FXI.

The importance of the feedback loop of thrombin on FXI in vivo is illustrated by the association between FXI levels and the risk of venous thromboembolism, as well as by the fact that FXI deficiency increases the risk of post-traumatic bleeding $[13,49,50]$. In light of this, the ability of the fibrinogen $\gamma^{\prime}$ peptide to inhibit FXI activation may be 
clinically relevant, since FXI recently emerged as a novel therapeutic target for antithrombotic therapy without increased risk for bleeding $[43,51,52]$.

As observed in previous studies, decreasing the $\mathrm{NaCl}$ concentration greatly enhanced FXI activation by thrombin. This may be an ionic strength effect (reducing ionic strength generally favors electrostatic interactions between proteins) or a specific effect related to the occupation of the $\mathrm{Na}^{+}$-binding site of thrombin [24]. In fact, the $\mathrm{NaCl}$ concentration determines the fraction of thrombin molecules that are in the $\mathrm{Na}^{+}$containing 'fast' (active) conformation. To distinguish between these two possibilities, we measured thrombin-catalyzed FXI activation at different concentrations of $\mathrm{NaCl}$ or tetrapropylammonium chloride, whose cation does not fit in the $\mathrm{Na}^{+}$-binding pocket of thrombin. At equal ionic strength, the $\mathrm{FXI}$ activation rate was higher with $\mathrm{NaCl}$ than with tetrapropylammonium chloride, suggesting a specific effect of $\mathrm{Na}^{+}$via occupation of the $\mathrm{Na}^{+}$-binding site of thrombin. In other words, these data indicate that $\mathrm{Na}^{+}$bound thrombin (previously known as "fast" thrombin) is a better FXI activator than "slow" thrombin. At high salt concentrations this positive effect is overruled by the inhibition of electrostatic interactions.

In summary, we have shown that thrombin and FXI bind to negatively charged phospholipids and that membrane surfaces with a high content of negatively charged phospholipids enhance thrombin-catalyzed FXI activation. Since binding and stimulation were only observed at low $\mathrm{NaCl}$ concentration and in the absence of $\mathrm{Ca}^{2+}$, the physiological significance of these findings remains doubtful. Moreover, we showed that the fibrinogen $\gamma^{\prime}$ peptide inhibits thrombin-mediated FXI activation, thereby unravelling another effect of the fibrinogen $\gamma^{\prime}$ chain $\mathrm{C}$-terminal end binding to thrombin exosite II.

\section{Acknowledgements}

We thank Mr. R. Schrijver for his excellent assistance with the Biacore experiments. We are also grateful to Dr. J.W. Govers-Riemslag and Prof. J.H. Morrissey for sharing dextran sulfate and polyphosphate, respectively. This work was supported by grant 2011-2 from the Dutch Thrombosis Foundation. 


\section{References}

1. Seligsohn U. Factor XI in haemostasis and thrombosis: past, present and future. Thromb Haemost 2007; 98(1): p. 84-9.

2. Matafonov A, Cheng $Q$, Geng $Y$, Verhamme IM, Umunakwe O, Tucker El, Sun MF, Serebrov V, Gruber A and Gailani D. Evidence for factor IX-independent roles for factor Xla in blood coagulation. J Thromb Haemost 2013; 11(12): p. 2118-27.

3. Emsley J, McEwan PA and Gailani D. Structure and function of factor XI. Blood 2010; 115(13): p. 2569-77.

4. Bouma BN and Griffin JH. Human blood coagulation factor XI. Purification, properties, and mechanism of activation by activated factor XII. J Biol Chem 1977; 252(18): p. 6432-7.

5. Geng Y, Verhamme IM, Smith SB, Sun MF, Matafonov A, Cheng Q, Smith SA, Morrissey JH and Gailani D. The dimeric structure of factor XI and zymogen activation. Blood 2013; 121(19): p. 3962-9.

6. Naito K and Fujikawa K. Activation of human blood coagulation factor XI independent of factor XII. Factor XI is activated by thrombin and factor Xla in the presence of negatively charged surfaces. J Biol Chem 1991; 266(12): p. 7353-8.

7. Gailani D and Broze GJ, Jr. Factor XI activation in a revised model of blood coagulation. Science 1991; 253(5022): p. 909-12.

8. Gailani D and Smith SB. Structural and functional features of factor XI. J Thromb Haemost 2009; 7 Suppl 1: p. 75-8.

9. Kravtsov DV, Matafonov A, Tucker EI, Sun MF, Walsh PN, Gruber A and Gailani D. Factor XI contributes to thrombin generation in the absence of factor XII. Blood 2009; 114(2): p. 452-8.

10. von dem Borne PA, Meijers JC and Bouma BN. Feedback activation of factor XI by thrombin in plasma results in additional formation of thrombin that protects fibrin clots from fibrinolysis. Blood 1995; 86(8): p. 3035-42.

11. Von dem Borne PA, Bajzar L, Meijers JC, Nesheim ME and Bouma BN. Thrombin-mediated activation of factor $\mathrm{XI}$ results in a thrombin-activatable fibrinolysis inhibitor-dependent inhibition of fibrinolysis. J Clin Invest 1997; 99(10): p. 2323-7.

12. Minnema MC, Friederich PW, Levi M, von dem Borne PA, Mosnier LO, Meijers JC, Biemond $\mathrm{BJ}$, Hack CE, Bouma BN and ten Cate H. Enhancement of rabbit jugular vein thrombolysis by neutralization of factor XI. In vivo evidence for a role of factor XI as an anti-fibrinolytic factor. J Clin Invest 1998; 101(1): p. 10-4.

13. Duga $\mathrm{S}$ and Salomon O. Congenital factor XI deficiency: an update. Semin Thromb Hemost 2013; 39(6): p. 621-31.

14. Gailani D and Broze GJ, Jr. Effects of glycosaminoglycans on factor XI activation by thrombin. Blood Coagul Fibrinolysis 1993; 4(1): p. 15-20.

15. Choi SH, Smith SA and Morrissey JH. Polyphosphate is a cofactor for the activation of factor XI by thrombin. Blood 2011; 118(26): p. 6963-70. 
16. Wu W, Sinha D, Shikov S, Yip CK, Walz T, Billings PC, Lear JD and Walsh PN. Factor XI homodimer structure is essential for normal proteolytic activation by factor XIla, thrombin, and factor Xla. J Biol Chem 2008; 283(27): p. 18655-64.

17. Oliver JA, Monroe DM, Roberts HR and Hoffman M. Thrombin activates factor XI on activated platelets in the absence of factor XII. Arterioscler Thromb Vasc Biol 1999; 19(1): p. 170-7.

18. Wielders SJ, Beguin S, Hemker HC and Lindhout T. Factor XI-dependent reciprocal thrombin generation consolidates blood coagulation when tissue factor is not available. Arterioscler Thromb Vasc Biol 2004; 24(6): p. 1138-42.

19. Baglia FA, Badellino KO, Li CQ, Lopez JA and Walsh PN. Factor XI binding to the platelet glycoprotein Ib-IX-V complex promotes factor XI activation by thrombin. J Biol Chem 2002; 277(3): p. 1662-8.

20. Yun TH, Baglia FA, Myles T, Navaneetham D, Lopez JA, Walsh PN and Leung LL. Thrombin activation of factor $\mathrm{XI}$ on activated platelets requires the interaction of factor $\mathrm{XI}$ and platelet glycoprotein Ib alpha with thrombin anion-binding exosites I and II, respectively. J Biol Chem 2003; 278(48): p. 48112-9.

21. Baglia FA, Shrimpton CN, Emsley J, Kitagawa K, Ruggeri ZM, Lopez JA and Walsh PN. Factor $\mathrm{XI}$ interacts with the leucine-rich repeats of glycoprotein Ibalpha on the activated platelet. J Biol Chem 2004; 279(47): p. 49323-9.

22. Maas C, Meijers JC, Marquart JA, Bakhtiari K, Weeterings C, de Groot PG and Urbanus RT. Activated factor $\mathrm{V}$ is a cofactor for the activation of factor $\mathrm{XI}$ by thrombin in plasma. Proc Natl Acad Sci U S A 2010; 107(20): p. 9083-7.

23. Di Cera E, Guinto ER, Vindigni A, Dang QD, Ayala YM, Wuyi M and Tulinsky A. The Na+ binding site of thrombin. J Biol Chem 1995; 270(38): p. 22089-92.

24. Di Cera E. Thrombin: a paradigm for enzymes allosterically activated by monovalent cations. CR Biol 2004; 327(12): p. 1065-76.

25. Bock PE, Panizzi $P$ and Verhamme IM. Exosites in the substrate specificity of blood coagulation reactions. J Thromb Haemost 2007; 5 Suppl 1: p. 81-94.

26. Huntington JA. How $\mathrm{Na}+$ activates thrombin--a review of the functional and structural data. Biol Chem 2008; 389(8): p. 1025-35.

27. Kamath $P$, Huntington $J A$ and Krishnaswamy $S$. Ligand binding shuttles thrombin along a continuum of zymogen- and proteinase-like states. J Biol Chem 2010; 285(37): p. 28651-8.

28. Lechtenberg BC, Freund SM and Huntington JA. An ensemble view of thrombin allostery. Biol Chem 2012; 393(9): p. 889-98.

29. Lane DA, Philippou H and Huntington JA. Directing thrombin. Blood 2005; 106(8): p. 260512.

30. Matafonov A, Sarilla S, Sun MF, Sheehan JP, Serebrov V, Verhamme IM and Gailani D. Activation of factor XI by products of prothrombin activation. Blood 2011; 118(2): p. 43745.

31. Fredenburgh JC, Stafford AR, Leslie BA and Weitz JI. Bivalent binding to gammaA/gamma'fibrin engages both exosites of thrombin and protects it from inhibition by the antithrombin-heparin complex. J Biol Chem 2008; 283(5): p. 2470-7. 
32. Lovely RS, Rein CM, White TC, Jouihan SA, Boshkov LK, Bakke AC, McCarty OJ and Farrell DH. gammaA/gamma' fibrinogen inhibits thrombin-induced platelet aggregation. Thromb Haemost 2008; 100(5): p. 837-46.

33. Lancellotti S, Rutella S, De Filippis V, Pozzi N, Rocca B and De Cristofaro R. Fibrinogenelongated gamma chain inhibits thrombin-induced platelet response, hindering the interaction with different receptors. J Biol Chem 2008; 283(44): p. 30193-204.

34. Omarova F, Uitte De Willige S, Ariens RA, Rosing J, Bertina RM and Castoldi E. Inhibition of thrombin-mediated factor $\mathrm{V}$ activation contributes to the anticoagulant activity of fibrinogen gamma'. J Thromb Haemost 2013; 11(9): p. 1669-78.

35. Lovely RS, Boshkov LK, Marzec UM, Hanson SR and Farrell DH. Fibrinogen gamma' chain carboxy terminal peptide selectively inhibits the intrinsic coagulation pathway. $\mathrm{Br} J$ Haematol 2007; 139(3): p. 494-503.

36. Omarova F, Uitte de Willige S, Simioni P, Ariens RA, Bertina RM, Rosing J and Castoldi E. Fibrinogen gamma' increases the sensitivity to activated protein $\mathrm{C}$ in normal and factor $\mathrm{V}$ Leiden plasma. Blood 2014; 124(9): p. 1531-8.

37. Bakker HM, Tans G, Janssen-Claessen T, Thomassen MC, Hemker HC, Griffin JH and Rosing $J$. The effect of phospholipids, calcium ions and protein $\mathrm{S}$ on rate constants of human factor Va inactivation by activated human protein C. Eur J Biochem 1992; 208(1): p. 171-8.

38. Segers K, Dahlback B, Bock PE, Tans G, Rosing J and Nicolaes GA. The role of thrombin exosites I and II in the activation of human coagulation factor V. J Biol Chem 2007; 282(47): p. 33915-24.

39. Macaya RF, Schultze P, Smith FW, Roe JA and Feigon J. Thrombin-binding DNA aptamer forms a unimolecular quadruplex structure in solution. Proc Natl Acad Sci U S A 1993; 90(8): p. 3745-9.

40. Pedicord DL, Seiffert D and Blat Y. Feedback activation of factor XI by thrombin does not occur in plasma. Proc Natl Acad Sci U S A 2007; 104(31): p. 12855-60.

41. Schumacher WA, Luettgen JM, Quan ML and Seiffert DA. Inhibition of factor Xla as a new approach to anticoagulation. Arterioscler Thromb Vasc Biol 2010; 30(3): p. 388-92.

42. Müller F, Gailani D and Renné T. Factor XI and XII as antithrombotic targets. Curr Opin Hematol 2011; 18(5): p. 349-55.

43. Gailani D, Bane CE and Gruber A. Factor XI and contact activation as targets for antithrombotic therapy. J Thromb Haemost 2015.

44. Mutch NJ, Myles T, Leung LL and Morrissey JH. Polyphosphate binds with high affinity to exosite II of thrombin. J Thromb Haemost 2010; 8(3): p. 548-55.

45. Bode W. Structure and interaction modes of thrombin. Blood Cells Mol Dis 2006; 36(2): p. 122-30.

46. Fenton JW, 2nd, Witting JI, Pouliott C and Fareed J. Thrombin anion-binding exosite interactions with heparin and various polyanions. Ann N Y Acad Sci 1989; 556: p. 158-65.

47. Baglia FA, Shrimpton CN, Lopez JA and Walsh PN. The glycoprotein Ib-IX-V complex mediates localization of factor XI to lipid rafts on the platelet membrane. $J$ Biol Chem 2003; 278(24): p. 21744-50. 
48. von dem Borne PA, Mosnier LO, Tans G, Meijers JC and Bouma BN. Factor XI activation by meizothrombin: stimulation by phospholipid vesicles containing both phosphatidylserine and phosphatidylethanolamine. Thromb Haemost 1997; 78(2): p. 834-9.

49. Salomon O, Steinberg DM, Zucker M, Varon D, Zivelin A and Seligsohn U. Patients with severe factor XI deficiency have a reduced incidence of deep-vein thrombosis. Thromb Haemost 2011; 105(2): p. 269-73.

50. Meijers JC, Tekelenburg WL, Bouma BN, Bertina RM and Rosendaal FR. High levels of coagulation factor XI as a risk factor for venous thrombosis. N Engl J Med 2000; 342(10): p. 696-701.

51. Gailani D. Future prospects for contact factors as therapeutic targets. Hematology Am Soc Hematol Educ Program 2014; 2014(1): p. 52-9.

52. Buller HR, Bethune C, Bhanot S, Gailani D, Monia BP, Raskob GE, Segers A, Verhamme P, Weitz $\mathrm{JI}$ and Investigators F-AT. Factor XI antisense oligonucleotide for prevention of venous thrombosis. N Engl J Med 2015; 372(3): p. 232-40. 


\section{Chapter 5}

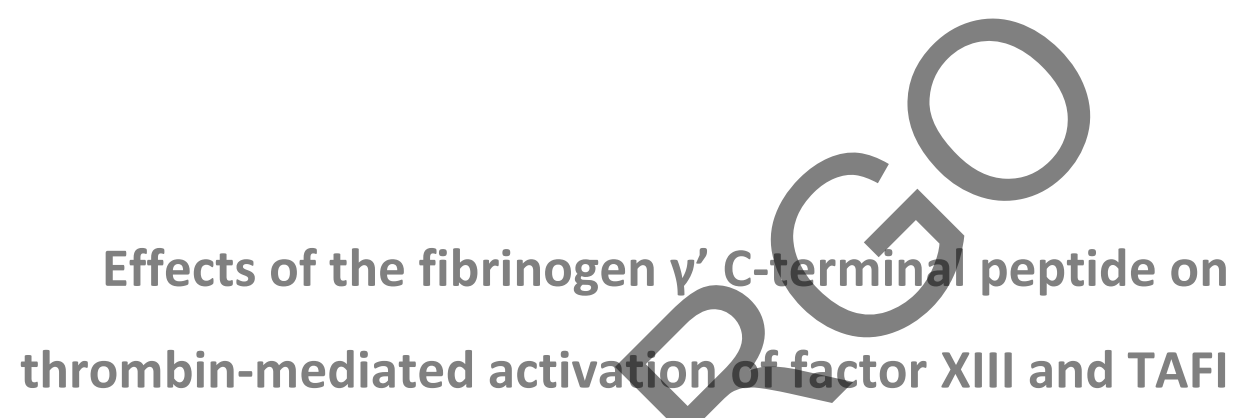

Farida Omarova, Jan Rosing, Robert A.S. Ariëns, Rogier M. Bertina, Elisabetta Castoldi 


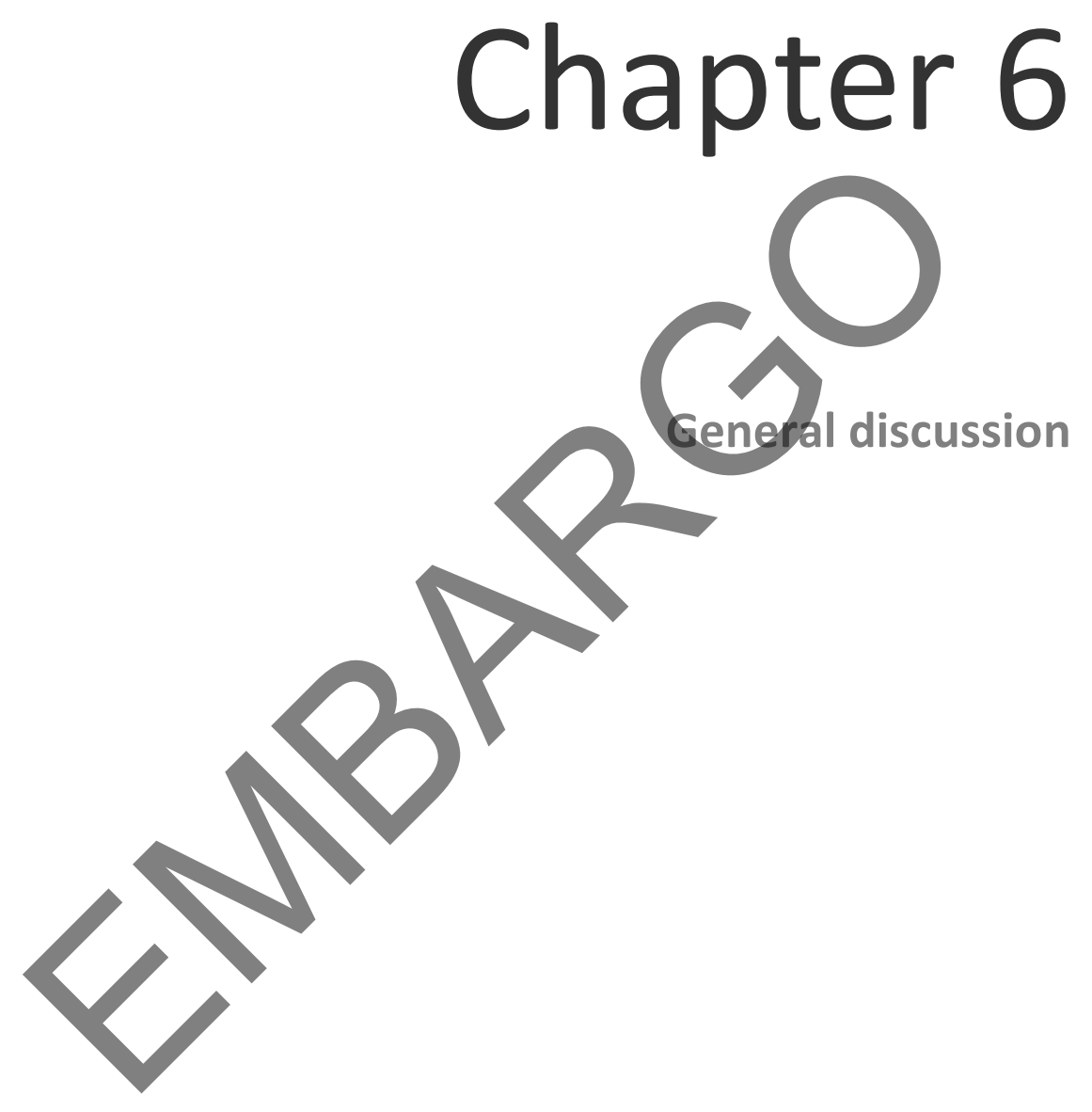




\section{Appendix}

Summary 


\section{Summary}

The function of the hemostatic system is to stop blood loss after vascular damage. The hemostatic response includes the formation of a platelet plug at the site of vascular injury and its subsequent stabilization with a fibrin network which is formed by the coagulation cascade. The enzyme thrombin regulates clot formation and degradation by converting fibrinogen into fibrin and by activating platelets, several coagulation factors (FV, FVIII, FXI and FXIII), an anticoagulant protein (protein C) and a fibrinolysis inhibitor (TAFI). The latter two functions require thrombin to be bound to its endothelial receptor thrombomodulin (TM). Overactive coagulation (hypercoagulability) causes excessive blood clotting, which may lead to thrombotic disorders.

Fibrinogen is a large liver-derived glycoprotein which circulates in plasma at a concentration of approximately $9 \mu \mathrm{M}$. Every fibrinogen molecule comprises two sets of three chains ( $A \alpha, B \beta$ and $\gamma$ ) each encoded by a different gene. Approximately $8-15 \%$ of all fibrinogen molecules contain an alternatively spliced variant of the $\gamma$ chain, known as $\gamma^{\prime}$ chain, which binds to thrombin with high affinity and modulates its activity. Low levels of fibrinogen $\gamma^{\prime}$ (i.e. fibrinogen containing the $\gamma^{\prime}$ chain), such as predicted by the FGG $\mathrm{H} 2$ haplotype, have been associated with increased risk of venous thrombosis. The work described in this thesis was aimed at better understanding of this association by elucidating how the interaction of thrombin with fibrinogen $\gamma^{\prime}$ modifies its activity on its numerous substrates. Since it was previously demonstrated that fibrinogen $\gamma^{\prime}$ inhibits thrombin-mediated platelet aggregation and FVIII activation, we focused on the remaining substrates of thrombin, namely FV, FXI, FXIII, protein C and TAFI. The effect of fibrinogen $\gamma^{\prime}$ on thrombin-mediated activation of these substrates was studied in model systems using a short peptide with an amino acid sequence identical to that of the thrombin-binding site on fibrinogen $\gamma^{\prime}$. The overall effect of fibrinogen $\gamma^{\prime}$ on coagulation in plasma was evaluated using the thrombin generation assay.

Chapter 1 introduces the hemostatic system and provides a detailed overview of the coagulation process. Thrombin structure, functions and substrates are reviewed. Furthermore, the structure and functions of fibrinogen and particularly fibrinogen $\gamma^{\prime}$ are described. In addition, this chapter provides a detailed overview of our current knowledge of the specific effects of this form of fibrinogen on components of the 
hemostatic system and its relationship with clinical conditions. Lastly, the calibrated automated thrombography (CAT) assay that measures thrombin generation is described.

The work presented in Chapter $\mathbf{2}$ demonstrates that fibrinogen prolongs the lag time of thrombin generation at low procoagulant stimuli. This study also shows that the synthetic fibrinogen $\gamma^{\prime}$ peptide effectively inhibits thrombin generation. Furthermore, we show that the fibrinogen $\gamma^{\prime}$ peptide inhibits FV activation by thrombin, both in a model system and in plasma, which suggests a novel mechanism underlying the anticoagulant effect of fibrinogen $\gamma^{\prime}$. This may contribute to the increased risk of venous thrombosis associated with reduced fibrinogen $\gamma^{\prime}$ levels such as predicted by the $F G G \mathrm{H} 2$ haplotype.

In Chapter $\mathbf{3}$ we elaborate on the observation that in carriers of the FV Leiden mutation (the most common hereditary cause of APC resistance) carriership of the FGG $\mathrm{H} 2$ haplotype is associated with a reduced sensitivity to activated protein C (APC), suggesting a relationship between fibrinogen $\gamma^{\prime}$ and plasma APC resistance. Using a plasma model system, we confirm that fibrinogen and particularly its $\gamma A / \gamma^{\prime}$ isoform increases the APC sensitivity in normal and FV Leiden plasma. Moreover, we show that this effect can be reproduced by the fibrinogen $\gamma^{\prime}$ peptide and is likely explained by the ability of the peptide to inhibit thrombin-mediated FV and FVIII activation, resulting in reduced FVa and FVIIla formation, which makes it easier for APC to inhibit thrombin generation via inactivation of FVa and FVIIla. Although the fibrinogen $\gamma^{\prime}$ peptide also inhibits protein $\mathrm{C}$ activation by the thrombin/TM complex, causing less APC to be generated, its net effect in plasma is still anticoagulant, as shown by the effect of the peptide on the response of plasma to the addition of TM, which leads to the activation of endogenous protein $C$.

While setting the conditions to investigate the effect of the fibrinogen $\gamma^{\prime}$ peptide on FXI activation by thrombin, we came across the complexity of this reaction in vitro. Chapter 4 describes the stimulatory effect of $\mathrm{Na}^{+}$binding to thrombin and the inhibitory effect of increased ionic strength on thrombin-catalyzed FXI activation. Additionally, we provide evidence that negatively charged phospholipid surfaces may act as a (physiological) cofactor for thrombin-mediated FXI activation by showing that thrombin and FXI both bind to negatively charged phospholipids and that negatively charged phospholipid vesicles considerably stimulate FXI activation by thrombin. Moreover, we demonstrate that the fibrinogen $\gamma^{\prime}$ peptide inhibits thrombin-mediated 
FXI activation, proposing a novel mechanism that can contribute to the overall anticoagulant effect of the peptide.

In Chapter 5 we report that the fibrinogen $\gamma^{\prime}$ peptide inhibits the activation of TAFI by the thrombin/TM complex. In contrast, thrombin-mediated FXIII activation was not affected by the peptide neither in the absence nor in the presence of purified fibrinogen, a cofactor of the reaction. Combined with previously published results, these findings complete the overview of the effects of the fibrinogen $\gamma^{\prime}$ peptide on all functions of thrombin.

Finally, in Chapter 6 we discuss the main findings presented in this thesis and summarize the general conclusions. This chapter also provides an analysis of the results in relation to published research, and shows how our studies contribute to the understanding of the overall properties of fibrinogen $\gamma^{\prime}$ and particularly of its binding to thrombin. Since thrombin plays an essential role in the hemostatic process, it is important to have a complete understanding of the effects of fibrinogen $\gamma^{\prime}$ on the major functions of thrombin. Our studies help to explain why low levels of fibrinogen $\gamma^{\prime}$ are associated with thrombotic disorders in humans and provide a basis for the design of novel antithrombotic treatments. Finally, we describe possible implications of the findings and provide future research perspectives. 
Samenvatting 


\section{Samenvatting}

De primaire functie van het hemostase systeem is het stoppen van bloedverlies dat optreedt na beschadiging van de wand van een bloedvat (wond). De hemostase respons omvat de vorming van een bloedplaatjesprop ter hoogte van de vasculaire schade, die vervolgens verstevigd wordt door een fibrinenetwerk, gevormd door de stollingscascade. Het enzyme trombine reguleert de vorming en afbraak van deze prop (klonter) door het omzetten van fibrinogeen in fibrine en door het activeren van bloedplaatjes, verschillende stollingsfactoren (FV, FVIII, FXI en FXIII), het antistollingseiwit proteïne $C$ en de fibrinolyse remmer TAFI. Voor de activering van de laatste twee genoemde factoren is het noodzakelijk dat trombine gebonden is aan de endotheel receptor trombomoduline (TM). Overmatige bloedstolling kan leiden tot ongewenste bloedstolsels, die op hun beurt kunnen resulteren in trombotische aandoeningen.

Fibrinogeen is een glycoproteïne met een hoog molecuulgewicht wat gesynthetiseerd wordt in de lever. Het circuleert in het plasma in een concentratie van ongeveer $9 \mu \mathrm{M}$. Het fibrinogeen molecuul is een dimeer bestaande uit twee sets van drie ketens ( $A \alpha$, $B \beta$ en $\gamma$ ), die elk gecodeerd worden door een afzonderlijk gen. Ongeveer 8-15\% van de fibrinogeen moleculen aanwezig in het bloed bevatten een alternatieve splicevariant van de $\gamma$ keten, ook wel de $\gamma^{\prime}$ keten genoemd. De $\gamma^{\prime}$ keten bindt aan trombine met een hoge affiniteit en moduleert na binding de enzymatische activiteit van trombine. Het FGG $\mathrm{H} 2$ haplotype is geassocieerd met verminderde hoeveelheden fibrinogeen met een $\gamma^{\prime}$ keten hetgeen kan leiden tot een verhoogd risico op veneuze trombose. Het onderzoek beschreven in dit proefschrift was met name gericht op het verwerven van meer inzicht in de associatie tussen fibrinogeen $\gamma^{\prime}$ en het risico op veneuze trombose. Hierbij werd onder andere specifiek aandacht besteed aan de vraag hoe de interactie tussen fibrinogeen $\gamma^{\prime}$ en trombine de trombine activiteit ten opzichte van haar substraten beïnvloedt. Eerder werd al aangetoond dat fibrinogeen $\gamma^{\prime}$ de trombinegemedieerde bloedplaatjesaggregatie en FVIII activering door trombine remt. Dit proefschrift beschrijft onderzoek naar het effect van fibrinogeen $\gamma^{\prime}$ op de andere substraten van trombine, waaronder FV, FXI, FXIII, proteïne C en TAFI. Het effect van fibrinogeen $\gamma^{\prime}$ op trombine-gemedieerde activering van deze substraten werd bestudeerd in model systemen waarbij gebruik gemaakt werd van een kort peptide 
met een aminozuurvolgorde die gelijk is aan die van de trombine bindingsplaats op fibrinogeen $\gamma^{\prime}$. Het algehele effect van fibrinogeen $\gamma^{\prime}$ in het bloedplasma werd geëvalueerd door gebruik te maken van de trombinegeneratie test.

In hoofdstuk 1 wordt het hemostase systeem geïntroduceerd en wordt een gedetailleerd overzicht gegeven van het bloedstollingsproces. Voorts worden de structuur en de functies van trombine en haar substraten verder in detail toegelicht. Ook wordt er aandacht besteed aan de structuur en functies van fibrinogeen, in het bijzonder van fibrinogeen $\gamma^{\prime}$. Daarnaast beschrijft dit hoofdstuk onze huidige kennis met betrekking tot de specifieke effecten van deze fibrinogeen variant op de componenten van het hemostase systeem en de klinische condities waarmee fibrinogeen $\gamma^{\prime}$ in verband wordt gebracht. Tenslotte wordt de meting van de trombine vorming met behulp van de calibrated automated thrombography (CAT) assay beschreven.

Het onderzoek beschreven in hoofdstuk 2 toont aan dat wanneer de stolling geïnitieerd wordt met lage concentraties weefselfactor, fibrinogeen de lag time van trombinevorming aanzienlijk verlengt. Deze studie laat tevens zien dat het synthetisch fibrinogeen $\gamma^{\prime}$ peptide in staat is op effectieve wijze de trombinevorming te remmen. Voorts wordt er in dit hoofdstuk aangetoond dat, zowel in een model systeem als in het plasma, het fibrinogeen $\gamma^{\prime}$ peptide FV activering door trombine kan remmen, wat een nieuw mechanisme is dat kan bijdragen aan het anticoagulante effect van fibrinogeen $\gamma^{\prime}$. Dit mechanisme kan ook een rol spelen in het verhoogde risico op veneuze trombose, wat geassocieerd is met verlaagde fibrinogeen $\gamma^{\prime}$ hoeveelheden, zoals voorspeld door het FGG H2 haplotype.

In hoofdstuk 3 laten we zien dat in dragers van de FV Leiden mutatie (de meest voorkomende erfelijke oorzaak van APC resistentie) het dragerschap van het FGG $\mathrm{H} 2$ haplotype geassocieerd is met een verminderde gevoeligheid van de trombinevorming voor geactiveerd proteïne $C$ (APC), een cruciaal anticoagulant eiwit. Deze bevinding suggereert dat er mogelijk een relatie is tussen de effecten van fibrinogeen $\gamma^{\prime}$ en plasma APC resistentie. Dit werd bevestigd door de bevinding dat fibrinogeen, en met name de $\gamma \mathrm{A} / \gamma^{\prime}$ isovorm, de APC gevoeligheid van normaal en FV Leiden bloed plasma doet toenemen. Bovendien kon dit effect worden gereproduceerd door toevoeging van het fibrinogeen $\gamma^{\prime}$ peptide aan plasma. Deze bevinding wordt waarschijnlijk verklaard door het feit dat het $\gamma^{\prime}$ peptide de activering 
van FV en FVIII door trombine remt, waardoor er minder FVa en FVIIla gevormd wordt en het voor APC gemakkelijker wordt om de trombine vorming te remmen. Hoewel het fibrinogeen $\gamma^{\prime}$ peptide ook in staat is de proteïne $C$ activering door het trombine/TM complex te remmen, wat resulteert in de vorming van lagere hoeveelheden APC, blijkt het peptide in het plasma nog steeds een netto anticoagulant effect te hebben. Dit wordt geillustreerd door het effect van het peptide op de trombinevorming in plasma waarin APC endogeen gevormd wordt door toevoeging van trombomoduline.

Bij het bepalen van de experimentele condities noodzakelijk voor de bestudering van het effect van fibrinogeen $\gamma^{\prime}$ op de trombine-gemedieerde FXI activering, werd duidelijk hoe complex deze in vitro reactie was. Hoofdstuk 4 beschrijft het stimulerende effect van $\mathrm{Na}^{+}$binding op de activiteit trombine, alsmede het remmende effect van een verhoogde ionsterkte op de activering van FXI door trombine. Voorts tonen wij in dit hoofdstuk aan dat negatief geladen fosfolipide oppervlakken een mogelijke fysiologische cofactor zijn in de door trombine gemedieerde FXI activering. In dit hoofdstuk laten we zien dat trombine en FXI beide kunnen binden aan negatief geladen fosfolipiden en dat negatief geladen fosfolipide oppervlakken de activering van FXI door trombine stimuleren. Verder tonen we aan dat het fibrinogeen $\gamma^{\prime}$ peptide de door trombine gekatalyseerde FXI activering remt, hetgeen een nieuw mechanisme suggereert wat kan bijdragen aan de algemene antistollende werking van het peptide. In hoofdstuk 5 rapporteren we dat het fibrinogeen $\gamma^{\prime}$ peptide de activering van TAFI door het trombine/TM complex kan verhinderen. Trombine-gemedieerde FXIII activering, daarentegen, werd niet beïnvloed door het fibrinogeen $\gamma^{\prime}$ peptide, noch in aanwezigheid noch in afwezigheid van gezuiverd fibrinogeen, een cofactor van deze reactie. Gecombineerd met reeds gepubliceerde resultaten, geven deze bevindingen een volledig overzicht van de effecten van het fibrinogeen $\gamma^{\prime}$ peptide op de meest belangrijke functies van trombine.

In hoofdstuk 6 worden de conclusies van de studies beschreven in dit proefschrift samengevat en worden de belangrijkste bevindingen bediscussieerd. Het geeft een gedetailleerde analyse van alle resultaten in relatie tot de bestaande wetenschappelijke literatuur. Verder laten we in dit hoofdstuk zien hoe onze studies een bijdrage leveren aan het algemeen begrip van de eigenschappen van fibrinogeen $\gamma^{\prime}$, met name met betrekking tot de binding aan trombine. Aangezien trombine een 
cruciale rol speelt in de hemostase respons is het belangrijk om een volledig begrip te hebben van de effecten van fibrinogeen $\gamma^{\prime}$ op alle functies van trombine. De inzichten verkregen uit de studies gepresenteerd in dit proefschrift verklaren waarom lage concentraties fibrinogeen $\gamma^{\prime}$ geassocieerd zijn met trombotische aandoeningen in de mens, en leggen de basis voor de ontwikkeling van nieuwe antitrombotische therapieën. Tenslotte beschrijven we de mogelijke implicaties van onze bevindingen, en bediscussiëren we mogelijk relevante toekomstige onderzoeksperspectieven. 
Valorization 


\section{Valorization}

Venous thrombosis is the third most common cardiovascular disease in the Western world after coronary artery disease and stroke [1]. It is a prevalent illness and it occurs in 1 per 1000 persons per year and in 1 per 100 people over 75 years old per year (source: Dutch Heart Foundation). Venous thrombosis is a serious condition that can lead to a life-threatening complication known as pulmonary embolism. Presently used treatments for venous thrombosis increase risk of bleeding in patients. Therefore, scientific research on the mechanisms of venous thrombosis and the development of novel treatment options will be beneficial for thrombosis patients.

In order to perform research that provides directly applicable results and has a notable impact on society, scientific knowledge is needed. The knowledge is developed by fundamental research, the purpose of which is to improve our understanding of natural phenomena without necessarily finding solutions to practical problems. In other words, it is essential to acquire knowledge prior to finding ways how to use it for the benefit of society.

The work described in this thesis is an example of fundamental research. It has previously been discovered in population studies that people who have low levels of an alternatively spliced variant of fibrinogen $\gamma^{\prime}$ are at higher risk for venous thrombosis. Also, it has been shown that this form of fibrinogen specifically binds to thrombin exosite II and modulates thrombin activity. Our aim was to understand which of thrombin's functions are affected by fibrinogen $\gamma^{\prime}$, in order to get more insight in the association between low levels of fibrinogen $\gamma^{\prime}$ and risk for venous thrombosis.

First, we found that a peptide that resembles the C-terminal end of fibrinogen $\gamma^{\prime}$, which contains the thrombin exosite II-binding site, inhibits FV activation by thrombin. This, together with its previously described ability to inhibit FVIII activation, underlies the ability of fibrinogen $\gamma^{\prime}$ (peptide) to increase APC sensitivity of plasma. This effect is important, as APC resistance is the most common risk factor for venous thrombosis in Caucasians [2]. Since the causes of APC resistance are manifold, there is no specific treatment for this condition. The fibrinogen $\gamma^{\prime}$ peptide does not influence FVa and FVIIla to make them more sensitive to the inactivation by APC. Instead, it inhibits their production, making it easier for APC to down-regulate their activity. Therefore, the 
fibrinogen $\gamma^{\prime}$ peptide could be a universal solution to counteract APC resistance irrespective of its cause.

Antithrombotic medications that are currently used for treatment and prevention of thrombotic disorders increase the risk of bleeding, since they interfere with processes required for normal hemostasis. It is obvious that new anticoagulants that act on different components of the coagulation system are needed. FXI has recently become an attractive target for the development of alternative anticoagulant therapies, as decreasing its level and activity reduces the risk of venous thrombosis without increasing the risk of bleeding [3]. An antisense oligonucleotide decreasing FXI levels in a dose-dependent manner has been reported to be effective in reducing the risk of postoperative thrombosis without increasing bleeding in a clinical study with 300 patients [4]. These data support the efficacy and safety of anti-FXI approaches as a basis for developing pharmacologic strategies. Similarly, our finding that the fibrinogen $\gamma^{\prime}$ peptide inhibits thrombin-mediated FXI activation can also contribute to its therapeutic potential.

The advantage of the peptide compared to the whole fibrinogen $\gamma^{\prime}$ molecule is that the peptide has only the effects of binding to the exosite II of thrombin, and not the undesired effects of the whole fibrinogen $\gamma^{\prime}$ molecule on fibrin clot structure. In addition, since the peptide has the same amino acid sequence as the C-terminal end of fibrinogen $\gamma^{\prime}$, it is not foreign to the human body and will not induce immune reactions. The fibrinogen $\gamma^{\prime}$ peptide increases plasma APC sensitivity and inhibits FXI activation, making it an interesting means for future pharmacological interventions. In fact, a company that develops treatment and diagnostic tools based on the specific properties of fibrinogen $\gamma^{\prime}$ already exists. Among other products, a next generation anticoagulant based on the fibrinogen $\gamma^{\prime}$ C-terminal end peptide, is being developed [5].

We strongly believe that the findings described in this thesis will help advancing the development of novel anticoagulants. 


\section{References}

1. Naess IA, Christiansen SC, Romundstad P, Cannegieter SC, Rosendaal FR and Hammerstrom J. Incidence and mortality of venous thrombosis: a populationbased study. J Thromb Haemost 2007; 5(4): p. 692-9.

2. Griffin JH, Evatt B, Wideman C and Fernandez JA. Anticoagulant protein C pathway defective in majority of thrombophilic patients. Blood 1993; 82(7): p. 1989-93.

3. Gailani D, Bane CE and Gruber A. Factor XI and contact activation as targets for antithrombotic therapy. J Thromb Haemost 2015; 13(8): p. 1383-95.

4. Buller HR, Bethune C, Bhanot S, Gailani D, Monia BP, Raskob GE, Segers A, Verhamme $\mathrm{P}$, Weitz JI and Investigators F-AT. Factor XI antisense oligonucleotide for prevention of venous thrombosis. N Engl J Med 2015; 372(3): p. 232-40.

5. http://gamma-therapeutics.com/. 


\section{Curriculum Vitae}

Farida Omarova was born on the $8^{\text {th }}$ of March 1985 in Urzhar, Kazakhstan. After graduating from secondary school with distinction in 2002 in Urzhar, she started her medical training at the Kazakh National Medical University in Almaty, Kazakhstan. In 2008 she received her Medical degree and started her internship in several hospitals in Almaty. In 2009 she was awarded a government grant to study in the Master's program Clinical Molecular Sciences at Maastricht University, the Netherlands. During this study, she conducted internships at the Department of Biochemistry and the Department of Human Biology of Maastricht University. She obtained her Master's degree in September 2011. In October 2011 she started working as a PhD candidate at the Department of Biochemistry (School for Cardiovascular diseases, Maastricht University) under the supervision of Prof. J. Rosing, Prof. R.M. Bertina and Dr. E. Castoldi. During her PhD training she attended several courses organized by the School for Cardiovascular diseases at Maastricht University, the Dutch Society on Thrombosis and Haemostasis and the Dutch Heart Foundation. She presented her research at different national and international congresses and received a Young Investigator Award at the Congress of the International Society on Thrombosis and Haemostasis in Amsterdam (The Netherlands) in July 2013 as well as an Award of Scientific Excellence at the symposium of the Dutch Society on Thrombosis and Haemostasis in Koudekerke in April 2014. 


\section{Publications}

1. Omarova F, Uitte de Willige S, Ariëns RAS, Rosing J, Bertina RM, Castoldi E. Inhibition of thrombin-mediated factor $\mathrm{V}$ activation contributes to the anticoagulant activity of fibrinogen $\gamma^{\prime}$. J Thromb Haemost 2013; 11: 1669-78.

2. Omarova F, Uitte de Willige $S$, Simioni $P$, Ariëns RAS, Bertina RM, Rosing J, Castoldi E. Fibrinogen $\gamma^{\prime}$ increases the sensitivity to activated protein $\mathrm{C}$ in normal and factor V Leiden plasma. Blood 2014; 124: 1531-38.

3. Omarova F, Rosing J, Bertina RM, Castoldi E. Effects of negatively charged phospholipids and the fibrinogen $\gamma^{\prime}$ C-terminal peptide on factor XI activation by thrombin. In preparation.

4. Omarova F, Rosing J, Ariëns RAS, Bertina RM, Castoldi E. Effects of the fibrinogen $\gamma^{\prime}$ C-terminal peptide on thrombin-mediated activation of factor XIII and TAFI. In preparation. 


\section{Oral presentations}

1. Omarova F, Uitte de Willige S, Dirven RJ, Ariëns RAS, Rosing J, Bertina RM, Castoldi E. Total fibrinogen and fibrinogen $\gamma^{\prime}$ modulate thrombin generation in plasma. XXII International Fibrinogen Workshop. Brighton (UK), 4-6 $6^{\text {th }}$ July 2012.

2. Omarova F, Uitte de Willige $S$, Ariëns RAS, Rosing J, Bertina RM, Castoldi E. Inhibition of thrombin-mediated factor $V$ activation as a novel anticoagulant effect of fibrinogen $\gamma^{\prime}$. XXIV Congress of the International Society on Thrombosis and Haemostasis (ISTH). Amsterdam (The Netherlands), $1^{\text {st }}-4^{\text {th }}$ July 2013.

3. Omarova F, Uitte de Willige S, Simioni P, Ariëns RAS, Bertina RM, Rosing J, Castoldi E. Fibrinogen $\gamma^{\prime}$ increases the sensitivity to activated protein $C$ in normal and FV Leiden plasma. XXIV Congress of the International Society on Thrombosis and Haemostasis (ISTH). Amsterdam (The Netherlands), $1^{\text {st }}-4^{\text {th }}$ July 2013.

4. Omarova F, Uitte de Willige S, Simioni P, Ariëns RAS, Bertina RM, Rosing J, Castoldi E. Fibrinogen $\gamma^{\prime}$ increases the sensitivity to activated protein $\mathrm{C}$ in normal and FV Leiden plasma. Annual Meeting of the Dutch Society on Thrombosis and Haemostasis (NVTH). Koudekerke (The Netherlands), 9-10 ${ }^{\text {th }}$ April 2014.

5. Omarova F, Uitte de Willige $S$, Simioni P, Ariëns RAS, Bertina RM, Rosing J, Castoldi E. Fibrinogen $\gamma^{\prime}$ increases the sensitivity of plasma to activated protein C. XXIII International Fibrinogen Workshop. Marseille (France), 9-11 ${ }^{\text {th }}$ July 2014.

6. Omarova F, Uitte de Willige $S$, Ariëns RAS, Bertina RM, Rosing J, Castoldi E. Effect of fibrinogen $\gamma^{\prime}$ on factor $\mathrm{XI}$ activation by thrombin. XXV Congress of the International Society on Thrombosis and Haemostasis (ISTH). Toronto (Canada), 20-25 $5^{\text {th }}$ June 2015.

\section{Poster presentation}

Omarova F, Uitte de Willige S, Simioni P, Ariëns RAS, Bertina RM, Rosing J, Castoldi E. An alternatively spliced form of fibrinogen improves plasma sensitivity to activated protein C. CARIM Symposium. Maastricht (The Netherlands), $26^{\text {th }}$ November, 2014. 


\section{Awards}

Young Investigator Award at the XXIV Congress of the International Society on Thrombosis and Haemostasis (ISTH). Amsterdam (The Netherlands), $1^{\text {st }}-4^{\text {th }}$ July 2013.

Award of Scientific Excellence at the Annual Meeting of the Dutch Society on Thrombosis and Haemostasis (NVTH). Koudekerke (The Netherlands), 9-10 ${ }^{\text {th }}$ April 2014. 
Acknowledgments 
Life is full of surprises. Ten years ago I, a girl from a remote village in Kazakhstan, could not even imagine living in Europe, thousands of kilometers away, and doing scientific research! When I started with this $\mathrm{PhD}$ project five years ago, completing it seemed so unreal. And here I am, happy and proud to have made it to the finish! This would have never been possible without a number of people who helped in various ways. I would like to express my heartfelt gratitude to everyone who helped, guided, supported and cared about me during this period.

Dr. Elisabetta Castoldi, dear Betta, thank you for the opportunity to conduct a PhD project under your supervision. Not only are you a highly competent, skillful professional and devoted scientist, you are also a person with an amazing personality: extremely kind, helpful, polite, warm-hearted and patient. I am very thankful for all the work and effort that you put into this project. You taught me a lot about scientific research. You were always there for me when I needed your help, to answer questions, patiently explain everything I asked, discuss about thousands of subjects and provide moral support. I will never forget long hours spent in discussions, working in the lab together or just telling stories and laughing. During these years, I remember many times running to your room in panic because something was going wrong, and you could always find words to guide me in right direction. "Positive thinking" is one of your favorite phrases, and yes, it all turned out good!

Prof. dr. Rosing, dear Jan, I am really grateful for all the help I got from you. I have so many reasons to thank you! Thank you for always being there, ready to help and share your vast knowledge. You spent long hours trying to shed some light in the dense forest of biochemistry and enzyme kinetics. Thank you for being critical and skeptical about experiments, which proved to be really helpful in enhancing my scientific thinking skills. You generated ideas and suggestions that formed the basis of this project. I knew that I could always ask your advice and rely on your knowledge and intuition. You were always able to think of an experiment that could save any situation. Thank you also for all the funny stories, which you have oodles of.

Dear Prof. Bertina, my second promotor, a legendary figure in blood coagulation research. I am grateful that you established the roots of this project well before I started working on it. I would like to thank you for your valuable suggestions and ideas that you provided with great enthusiasm. Thank you for all your feedback and comments you provided on the publications and the thesis and for our fruitful and interesting meetings.

Prof. dr. Hackeng, dear Tilman. I am very grateful that you gave me the opportunity to work longer on my project. Thank you for being very accessible, helpful, reliable and 
cheerful. As the head of the department, you created a very friendly and cozy atmosphere among colleagues, which I really enjoyed all these years.

I would like to express my gratitude to my co-authors. Dr. Uitte de Willige, whose excellent PhD research provided a basis for this project. And Prof. dr. Ariëns, the expert in the subject of fibrinogen $\gamma^{\prime}$. Dear Shirley and dear Robert, thank you for interesting meetings and discussions and for your help in preparing the publications.

Next, I would like to thank my two lovely paranymphs. Dear Stella, the star of Biochemistry. You are a real professional, knowledgeable and skillful; thank you for all the help and advises concerning practical work. But even more I am thankful for our activities and talks not related to lab work. Over this time you have become a true friend. Thank you for being so kind, warm, supporting, caring, motivational, and enthusiastic. Dear Tanja, a colleague, a roommate and a friend. You are such an admirable person. Thank you for your support and care. It felt so great to be able to share with you anything (joy, fun, success, disappointment, private issues) and you understand exactly what I mean, even if we have to whisper so that no one hears (-). I wish you a smooth completion of your thesis and good luck in everything.

I am thankful to all the colleagues and ex-colleagues for their help, support and for creating a nice working environment. Dear Marijke and Johan, it is thanks to you that I started working at the Biochemistry department. When I started the internship with you I had no idea how to use a pipette. Thank you for teaching me the ins and outs of working in a laboratory and conduction research. Karin, thank you for all the talks (work-related and not), walks, dinners, borrels, and for keeping in touch. Francesca, you were my first officemate and roommate at congresses and courses, it was fun, thanks. I always enjoyed listening to you and Betta talk in Italian. Simone, thank you for all your help in the lab. You were always there to listen to me and find right words to cheer me up. Roy, my go-to guy in the lab. I really appreciated your help with Biacore, with buffers dialysis, and so many other things. Also, thanks for cheerful chats and funny jokes! Nahla, I admire your perseverance. Thank you for providing all the sweets/fruits and for all the cups of coffees and talks together. Stijn, if I needed an honest opinion on any topic, I knew I could ask you. Thank you for the movie nights and the nice atmosphere in the room. Степан, было приятно иметь возможность поговорить на русском языке не отходя от рабочего места, удачи во всем. Kristien, thank you for de gezelligheid in the lab and at borrels. Jiang, Sameera and Barbara, I was so glad that there were more international people in the department and thanks for a lovely trip to Poland. Guido and Rory, thank you for making the Thursday meetings so pleasant by showing a genuine interest and involvement in the 
presentations. Daniëlle, thank you for the nice talks and for organizing many social activities! Kanin, I wish you good luck with your further career and many more trips in the future. Alexandra, thanks for being helpful and friendly, I wish you good luck in your carrier. Ingrid, I admire your strength, both inner and outer. I would also like to thank all the other colleagues for the friendly chit-chats in the corridor, at lunches, borrels or labuitjes: Linda, Peter, Annemiek, Hans, Gerry, Dennis, Frauke, Susanne, Tom, Remco, Magdi, Rick, Armand, Brecht, Nico, Marion, Jose.

Trees, thank you for all the pleasant talks and administrative help. Also thank you Lidewij for nice conversations and help with paper work.

There are more people who I would like to thank.

Дорогая Настя, мы понимаем друг друга с полуслова и можем делиться самым сокровенным. Я рада что у меня есть такой друг. Спасибо тебе за все разговоры, переписки, визиты, поездки и посиделки. Алуа, еще одна казашка в Маастрихте, было приятно скрасить совместно дни на чужбине. Olivia, thanks for your friendship and good luck with your PhD in Bern.

My dear Koen, I am happy that you came into my life. Many thanks for your help and advises on finishing the thesis and searching for a job. Thank you also for the constant support, patience and care. We are a good team together. Lieve Monique en Theo, ik waardeer het echt dat jullie mij het gevoel geven dat ik bij jullie familie hoor. Dank $u$ wel voor de steun en zorg.

Мои любимые сестры, без вас ничего этого вообще не было бы. Сендердін арқаларында адам болдым. Ляззат, үлкен рахмет за все, за самоотверженную и бескорыстную помощь, за ведение моих дел, за то что научила многому в жизни, перечислить всего невозможно. Жанар, это ты сподвигла меня на перемены в жизни и настойчиво добивалась того чтобы я шла дальше, спасибо тебе за всю ту помощь и советы которые я получала и продолжаю получать от тебя. Мне безмерно повезло иметь таких сестер. Мама и папа. Эта диссертация написана благодаря вам и посвящена вам. Вы никогда не ограничивали меня и не сомневались в моих способностях и дали возможность и свободу делать то что я сама выбираю, я это очень высоко ценю. Мы так далеко друг от друга, но я постоянно чувствую вашу любовь, поддержку и заботу. Осы бәрі еңбектеріңіз үшін сендерге алғыс айтамын. 
